ntro
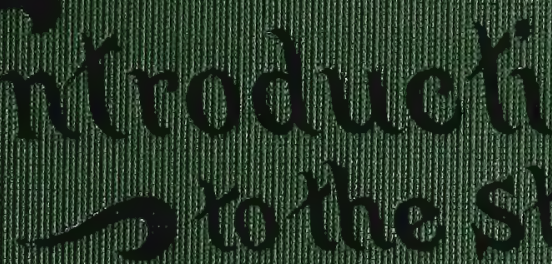

10.

at 1

(3)

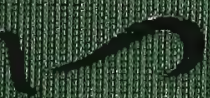

3 (1)

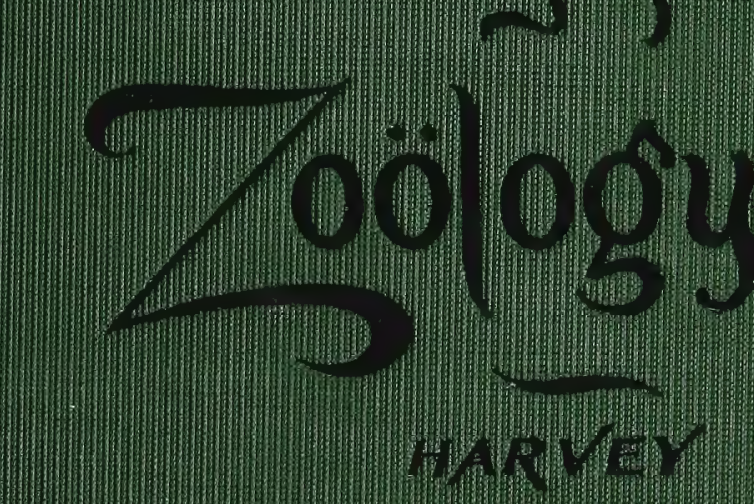

(19)

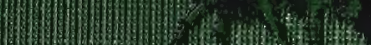

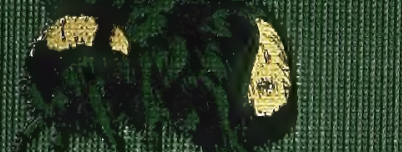

3. 


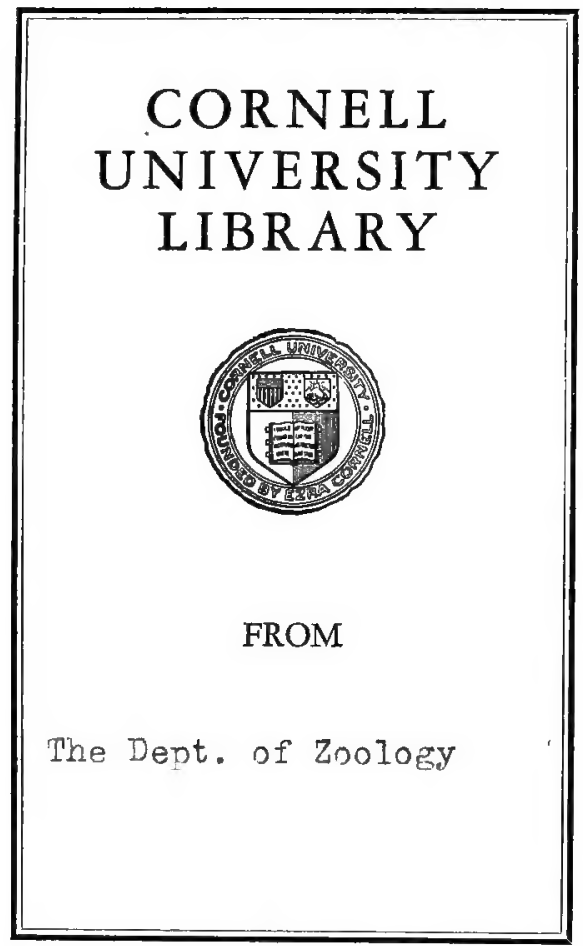




\section{QL 53.H34 \\ Cornell University Library}

Introduction to the study of zoology, fo

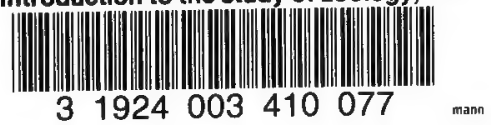




\section{Cornell University Library}

The original of this book is in the Cornell University Library.

There are no known copyright restrictions in the United States on the use of the text. 


\section{INTROD UCTION}

TO THE STUDY OF

\section{$\mathrm{Z} O \ddot{O} \mathrm{~L} O \mathrm{O} \quad \mathrm{Y}$}

FOR UST IN

\section{HIGH SCHOOLS AND ACADEMIES}

BY

N. A. H A R V E Y

Head Department Science, Chicago Normal Schoot

Pres. Dept. Soience, Not'l Educational Ass'n, 1901
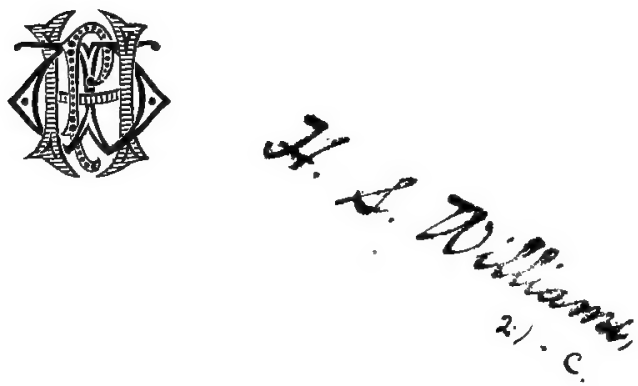

WESTERN PUBLISHING HOUSE 
COPYRIGHT, 1901, BY

WESTERN PUBLISHING HOUSE

Zoology--1-1

mogt O, LAW co.

PRINTERS ANO GINOERE

CHICADO 


\section{PREFACE.}

Almost every text-book on logic draws the majority of its illustrations of logical processes from the development of the subject matter of the natural sciences. The natural sciences most clearly manifest the universal method of discursive thought; therefore, it is difficult to overestimate their importance as an element in education.

Of all the natural sciences, zoölogy is the one which can be used with the greatest economy of effort to give the mind facility in certain fundamental activities which lie at the foundation of all processes of logical thinking.

As the writer conceives it, the pedagogical content of zoölogy consists in training the pupil to gather knowledge at first hand and to get clear ideas of the objects studied, and in exercising his mind in its power of abstraction, concrete analysis, discrimination, com-. parison, generalization, and logical definition and in the recognition of logical identity. The results of the study conducted under the influence of such a conception are likely to be very different from what they would be if it were believed that the knowledge of a few animals is the chief end sought. To leave zoölogy out of a course of instruction is to omit the training of the mind in these directions, or to accomplish the same result by a much greater expenditure of energy in another subject than would be necessary in this.

Just as the benefit derived from the study of algebra is not to be looked for in the information conveyed in the answers to the problems that the student so laboriously solves, and the value of the study of Latin comes not from the knowledge of the historical facts that the pupil learns while reading the Latin language, so the value of the study of zoölogy does not depend upon the knowledge, of animals that the student acquires, but rather upon the power that the student acquires while gaining that knowledge.

A commendable text-book on zoölogy for high schools must concern itself, then, not so much with the development of the subject as with the development of the human mind. This book is 
written fyom a pedagogical standpoint, and is intended to point out so carefully the content of the subject, and to indicate so clearly a method by which the content may be realized, that no teacher and no pupil who follows the plan here indicated can fail to realize a large part of the value to be derived from the study of elementary zoölogy.

There are at least three stages in the study of zoölogy. First, the one in which the student learns how to study and how to utilize zoölogical material. Knowledge of facts is a very subordinate aim in this stage, and the method of acquiring knowledge is very important. This is the stage of greatest educational value, and is but little transcended in high school work. It is the introductory stage, and justifies the name of Introduction for this book. The second stage is the one in which knowledge of facts is the chief end sought. It is essentially a reading stage. The student must read everything about the subject, or that part of the subject to which he turns his attention. The third stage is one in which the student undertakes original investigation and adds to the world's stock of knowledge.

This analysis shows us that the work of the introductory stage must be largely laboratory work. The writer fails to see how very much good can be obtained from the study of a science that is not pursued in this way. Even the reading of books is not to be recommended, unless they deal with phases of the subject that are not investigated in the laboratory, although in a few instances it has seemed impracticable to avoid giving some information in the text that might be derived from the study of the specimen itself.

In this book it is intended to combine the advantages of Natural History study with laboratory work in such a way that neither shall detract from the value of the other. Under the head of "Additional Facts" are stated life relations and habits of the animals studied which cannot be determined from an examination of their structure. Completeness or fullness in this respect is neither attempted nor desired, but enough is given to stimulate observation. The natural history text is limited to the animal forms studied in the laboratory, or to closely related animals, for it is very doubtful whether the reading about animals foreign to one's locality or experience is at all conducive to observation.

The principal emphasis is laid upon the branch of Arthropods, and the subject of insects is treated first. This is done deliberately and after much thought and trial of other ways. The first 
insects studied represent different families. By a comparison of these insects we generalize and rise to the conception of an Order. The next insects studied represent orders, and by a comparison of their resemblances we proceed to the conception of a Class. The table of differences enables us to frame a logical definition of each order. The next animals studied represent not orders, but classes. By a comparison of all these animals, we generalize and rise to the conception of a Branch. The next animals studied represent branches, and a similar process of the mind leads to the conception of a Kingdom.

It might be possible to use Vertebrates instead of Arthropods for the purpose of forming a conception of the less comprehensive groups, but the inconvenience would be greater. Near the seashore it might be possible to use Mollusks instead of Arthropods as the beginning of the work, but certainly not with such satisfactory assurances of success.

Because of the importance of vertebrate dissection in the study of human physiology, more attention is given to the Vertebrates than is really demanded by the logical development of the plan. The importance of Protozoa in the discussion of philosophic questions leads to a treatment of the subject seemingly inconsistent with the rest of the book, but which it is believed will prove an advantage to the users.

Certain philosophic principles are discussed, when occasions arise demanding their treatment, but nothing is touched upon that does not grow directly out of the laboratory work. Such are the topics of Protective Coloration, Mimicry, Protective Resemblance, Vestigial Organs, von Baer's Principle, Homology of Parts, Metamorphosis, Variation, Development, Economic Effect, Parasitism, Senses and Sense Organs.

Enough work is suggested to occupy the time of a class one period each day for one year of nine months. If a shorter time is given to the study, the teacher may make a selection in one of two ways. He may lay the emphasis upon a smaller number of groups, or upon a smaller number of animals in each group. According to the second plan, a good selection would be to study only the grasshopper, butterfly, beetle, housefly, crawfish, rabbit, clam, earthworm, starfish, hydra, sponge, paramoecium. The writer considers it more advantageous to limit the study to Arthropods if the time is very short.

This book is the outcome of ten years' experience in teaching 
elementary zoölogy to large classes, and everything indicated in it has stood the test of class-room work many times. It will be found serviceable in a laboratory that is well equipped for work, but is especially designed for those high schools whose equipments are the most meager and whose only hope of obtaining better facilities for teaching lies in making a success of the work with the facilities they already have.

The illustrations are nearly all of microscopic objects, and the only purpose in inserting them is to assist pupils that have not the opportunity to use a compound microscope.

Special attention is called to the forms of the tables of resemblances and differences, and to the demonstration of the homology of the mouth parts of the grasshopper (page 66), to the treatment of von Baer's Principle (page 99), to the three series (page 103), and to the demonstration of rank among animals (page 167).

Grateful acknowledgments for valuable suggestions are rendered to Prof. S. A. Forbes and Dr. Frank Smith of the University of Illinois, to President Howard Ayers of the University of Cincinnati, and to Dr. Frank J. Hall of the Kansas City Medical College. 


\section{SYNOPSIS OF CHAPTERS.}

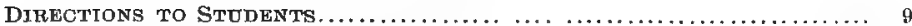

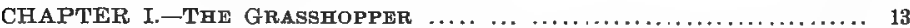

Laboratory directions-Pronunciation lists-The living grasshop. per-Microscopic objects: compound eye, crop, air tubes, eggs, and muscle-The young grasshopper-Examination questions-Review topics-Additional facts: the skeleton, molting, metamorphosis, senses, respiration, injuries to farm crops-Groups of animals-Rules for naming.

CHAPTER II.-OTHER ORTHOPTERA.

The cricket-Laboratory directions-Additional facts: color, ovipositor, deposition of the eggs-Microseopic objects: spiracle, gizzard, the on the wing-The katydid-Laboratory directions -Additional facts -The walking-stick-Laboratory directions-Additional facts: protective resemblance-Table of differences between the grasshopper, cricket, katydid, and walking-stick-Table of resemblances-Additional facts about the Orthoptera.

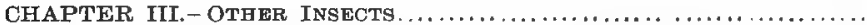

The butterfly-Laboratory directions-The caterpillar-Laboratory directions-The chrysalis and cocoon-Laboratory directions-The moth - Laboratory directions-Table of differences between a butterfly and a moth-Mieroscopic object: scales of a moth-Additional facts about Lepidoptera: metamorphosis, mouth parts and their homology, mimicry, silk, injurious Lepidoptera-The beetle-Laboratory directionsAdditional facts-The giant water bug-Laboratory directions-Additional facts-The cicada-Laboratory directions-Additional facts: the seventeen year cicada, injuries produced by Hemiptera, parthenogenesis -The house fly-Laboratory directions-Microscopic objects: proboscis, labellæ, lancets and palpi, foot, wing-Additional facts-The dragon fy -Laboratory directions-Adaitional facts-The bumblebee-Laboratory directions - The wasp-Laboratory directions - Microscopic objects: tongue of a bee, tongue of a wasp, sting of a wasp, hooks on the hind wing-Additional facts about Hymenoptera: metamorphosis; social organization; honey, nectar, pollen, and wax; use of the sting and poison; cross fertilization of plants; warning coloration; habits of solitary wasps; intelligence of ants-List of orders of insects-Pronunciation lists-Table of differences between insects-Table of resemblances -Logic?l definition-Definition of each order-Review topics on insects -General considerations about insects: how to collect and preserve insects. CHAPTER IV - ARACHNIDA AND MYRIAPODA............................... directions-Additional facts about Arachnida-The centipede-Laboratory directions - Thousand legs - Laboratory directions - Similarity between a caterpillar and a myriapod-Additional facts about myriapods: habits of life, homology of the maxillipeds, demonstration of the homology between the legs and the mandibles of a grasshopper.

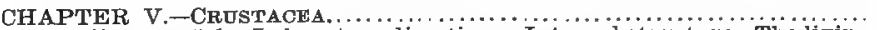

The craw tish-Laboratory directions-Internal structure-The living crawtish - The sow bug - Cyclops - Daphnia-Additional facts about 
Crustaceans-Review topics-Table of differences between a grasshopper. spider, centipede, and crawfish-Table of resemblances-Definition of an Arthropod.

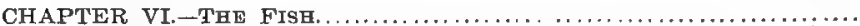

Laboratory directions - The live minnow-Additional facts about the Hsh: orders, method of breathing, action of gills, method of distribution, single circulation, homology of the air bladder-Review topicsVocabulary.

CHAPTER, VII. - BATRACHIA

The frog-Laboratory directions - Additional facts: method of breathing, circulation-Microscopic object: blood corpuscles-The toadTable of differences between a toac and a frog-Tadpole-Laboratory directions-Comparison of a tadpole and a flsh-Demonstration of von Baer's principle--The three series: ontogenetic, phylogenetic, taxonomic-Review topics on the frog.

CHAPTER VIII. -BIRDS AND REPTILES.. ...................... 104

The pigeon-Laboratory directions-Feathers-An egg-Table of differences between a pigeon and a fish-Additional facts: feathers, wing muscles, teeth, circulation, breathing, embryology, egg, air space, migration-Review topies on the pigeon-The turtle-Laboratory directions-Table of resemblances between a turtle and a pigeon-Additional facts-Archæopteryx.

CHAPTER IX-MAMMAIS....

The rabbit-Laboratory directions-Table of differences between a fish, frog, pigeon, tiurtle, and rabbit--Table of resemblances-Definition of each class of vertebrates-Definition of vertebrate-Table of differences between a grasshopper and a rabit-Additional facts ahout mam. mals: teeth, injuries, rabbits in Australia, checks on increase, pressure on subsistence, struggle for existence, survival of the fittest-Additional facts about vertebrates: amphioxus, notochord, vestigial organs.

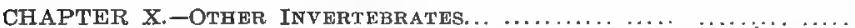

The fresh-water clam-Laboratory directions-Suggestive questions-Facts about the clam-The oyster-Table of differences between the oyster and the clam-Table of resernblances-The snail-Laboratory directions--Table of differences between the clam and the snail-Table of resemblances-Facts about the snail--Microscopic object: odontophore-The earthworm--Laboratory directions--Facts about the earth. worm: breathing, locomotion, life habits, other worms--Microscopic object: cross section-Table of differences between a caterpillar and an earthworm-The staresh--Laboratory directions--Facts about the starfsh: bilateral symmetry, water-pipe system-Review topies on the clam, snail, earthworm, and starish-Fresh-water hydra-Laboratory directions-Facts about the hydra-Fresh-water sponge-Laboratory directions-Facts about the sponge--Protozoa: vorticella, carchesium, epistylis, stentor, paramoecium, amoeba-Table of resemblances among vorticella, stentor, paramoecium, amoeba--Concept of a protozoan-Facts about the protozoa: practical immortality, reproduction, undifferenti. ated cell-Table of resemblances among rabbit, clam, grasshopper. earthworm, starfish, hydra, sponge, and paramoecium--Concept and definition of an animal-Differential table showing addition of organs to the different groups--Demonstration of rank among animals--Logical deftnition of each branch-General review topics.

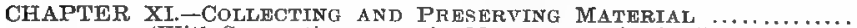
(With Suggestions upon its Management in the Class.)

CHAPTER XII--Classification OF ANIMALS.................... 182

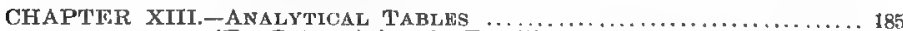

(For Determining the Families of Insects.) 


\section{INTRODUCTION}

\section{TO THE STUDY OF \\ Z $O \ddot{O} \mathrm{~L} O \mathrm{G}$ Y.}

DIRECTIONS TO STUDENTS.

The value of this work to you will depend largely upon how much of it is done without assistance. You are to acquire definite and exact information of the objects studied for the sake of learning how to acquire definite and exact information of objects in general. The solution of a problem in algebra is valuable not for the information acquired in the answer, but for the power acquired in learning how to find the answer.

The information about each specimen studied should be obtained from the specimen itself as far as such information can be thus obtained. It is a mistake to go to reference books, or to ask your neighbor or your teacher, for information about the specimen that the specimen itself can tell you. Some things the specimen cannot tell. Under the head of "Additional Facts," this book states some of the things about the animals studied which the specimens cannot tell. After an animal form has been studied, it is a good thing to read about it, but the reading should follow and not precede the laboratory study. 
You should keep in a notebook a faithful record of all your observations. Each observation should be written out in full, in ink, at the time it is made, in order that it shall be as complete as possible. "Writing makes an exact man." Do not try to make crude notes on a scratch-book and copy the notes afterward. Your book may thus become a copy-book, but it will not be a notebook. Sometimes an erroneous observation will be recorded. In such a case, the correction should be recorded in the notebook just when it is discovered, with the statement that an erroneous observation has been recorded on a certain preceding page. Nothing should be copied into the notebook from another book. It should contain only the record of your personal observations.

The drawings should be the best that you are capable of making. It will be found the most satisfactory to make the drawings with India ink, on good smooth paper, using a fine-pointed pen. The drawings should be line drawings, and every line should represent something on the object, and not be put in merely for looks. Drawing is a method of study, and everything that is studied should be drawn. The drawings, like the notes, should be made while the object is before you. Do not copy pictures from books. Copied pictures are worse than useless for purposes of this study.

There are two kinds of questions that you will be disposed to ask. One is a proper kind and one is an improper kind. For example, on the grasshopper you may be disposed to ask, "Where is the labial palpus?" This is an improper question. It means that you have somehow got hold of a name, and now are asking some one to show you the thing that fits it. The proper reply to your question is to say, "Ask the grasshopper." The other kind of question is a proper one. You say, "I have found something 
here. What is it?" You have found the thing. The name is not printed upon it, of course, and as the name is merely something that has been agreed upon by men to designate that thing, it must be given to you either by your book or by your teacher.

In all your work you must regard the animal as a living thing. It is not true that you are studying merely a dead form. On the grasshopper we study the eyes, because he sees with them; we study the antennæ, because he feels with them; the mouth parts, because he bites with them; the spiracles, because he breathes with them; the wings, because he flies with them; and so with every other structure that we study, it has some use or some meaning in the life of the animal, and it is a part of our work to see what that meaning is and to see how all the parts work together to enable the animal to live the life that he leads. Wherever possible, of course, the living animal is to be studied in its home.

The purpose of the laboratory directions in this book is to direct your study and not to give information. It is very difficult not to give too much information in the laboratory directions, but the attempt has been made to avoid it.

Much of the benefit to be derived from the study of zoölogy can be obtained from the study of the specimen even though you be supplied with the most meager apparatus. The hand lens seems to be the only piece of apparatus that is absolutely indispensable, although a better equipment will contribute very much to the efficiency of your work. You ought to have a copy of the text-book to guide you in the work, a specimen of the object to be studied, a notebook, and pen and ink with which to record your observations and make your drawings; you ought 
also to have a set of dissecting instruments, consisting of a lens, a scalpel, a pair of small, sharp-pointed scissors, and a pair of fine-pointed forceps; you should also have a dissecting dish, a small jar or wide-mouthed bottle for preserving your alcoholic material from day to day, a towel, and a piece of soap.

Suggestions about the collection and preservation of material and laboratory devices and management will be found in a chapter near the end of the book. 


\section{CHAPTER I.}

\section{THE GRASSHOPPER.}

1. Distinguish the head, thorax, and abdomen. These are called the body divisions.

\section{The Head.}

2. Find the antennæ. How many segments in each?

3. Find the compound eyes. Your lens will show only some fine lines running criss-cross over the surface.

4. Find three simple eyes (ocelli) on the head.

5. See the upper lip (labrum). Raise it. Cut it off. Examine the under side. Draw.

6. See the mandibles, or true jaws. Pry them apart. In what direction do they move? Pull one off. Examine. Draw.

7. Below the mouth is the labium, or lower lip. Is it a single appendage, or two united?

8. Find the labial palpi, attached to the labium. How many segments in each?

9. Find the maxillæ. These consist of three pieces each :-

(a) Maxillary palpus. How many segments?

(b) A spoon shaped piece, the galea.

(c) The lacinia, or maxilla proper. How many points has it?

10. Draw the head, as seen from the side. As seen from the front. 


\section{The Thorax.}

1. Locate the three parts of the thorax. The front one is the prothorax. This has no wings. The middle one is the mesothorax. The hind one is the metathorax.

2. Find a small opening just above the second pair of legs. This is a breathing pore, or spiracle. Find another in the soft skin between the pro- and mesothorax.

3. How does the prothorax differ from the mesoand metathorax? What is the advantage of the consolidation of the meso- and metathorax?

\section{The Wings.}

1. Spread out the fore and hind wings on the right side of the body. Draw both in this position. tached?

2. To what part of the thorax is each wing at-

3. Find the veins which constitute the framework of the wings.

4. State the difference between the fore and the hind wing, with reference to size, shape, color, texture, folding, use, position when at rest and when in motion.

\section{The Legs.}

1. Examine one of the hind legs. To what part of the thorax is it attached?

2. Find a short segment close to the body, the coxa.

3. Find the large segment (femur). The next segment is the tibia. See the spines behind. What is their use? The end of the leg is the tarsus. How many segments has it? Study the feet.

4. Examine the joint between the tibia and the femur. Draw the whole leg. 
5. Study one of the front legs in the same way. Note especially the foot. State how the front leg differs from the hind one. Draw.

6. In how many ways can a grasshopper travel? What difference in the use of the front legs and the hind legs?

7. Remove the legs and wings and draw the thorax, as seen from the side. As seen from below.

\section{The Abdomen.}

1. Locate the tergum, which is the upper or dorsal side of the body; the sternum, which is the ventral or lower side; and the pleurum, which is the lateral part between the sternum and the tergum. See the two grooves along the sides.

2. Count the segments of the abdomen. The last two do not go entirely around.

3. Find spiracles, or breathing holes, along the upper edge of the side grooves. How many?

4. Find the ear, on the first ring of the abdomen, under the wings. Is there a spiracle on this segment also?

5. If your specimen is a female, find the ovipositor, consisting of four parts, at the end of the abdomen. Draw.

If your specimen is a male, the end of the abdomen will be blunt and you will find two hooks (cerci) above it. Draw.

6. How many segments in the abdomen? How many in the thorax? How many pairs of paired appendages on the head? If each pair of appendages indicates a segment, how many segments in the head? How many segments make up the entire body?

7. Draw a side view of the entire grasshopper.

8. You ought now to have a drawing of the whole grasshopper, two views of the thorax, two views of the 
head, a drawing of each of the mouth parts, antennæ, ocelli, two legs, wings, and ovipositor.

9. What color is your grasshopper? Is this color an advantage? Would it be well for the grasshopper if it were bright red or blue or yellow? Are all grasshoppers the same color? Why?

10. Copy the following words into your notebook. Spell, pronounce, and tell what each word means.

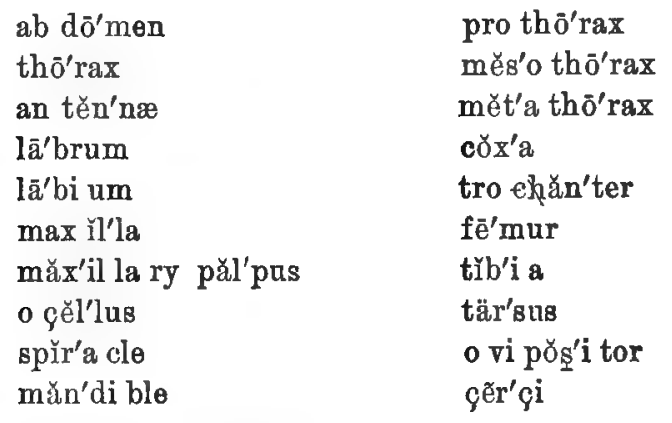

11. What do grasshoppers eat? Are they injurious to crops? Why are they not injurious every year? How many kinds of grasshoppers can you collect?

12. Can a grasshopper feel? See? Hear? Smell? Taste? With what organs can he smell? Taste?

13. How does a grasshopper escape from his enemies? What enemies?

14. How long does a grasshopper live?

\section{Internal Structure.}

1. Cut off the wings of a grasshopper that has been freshly killed. Pin it, back upward, on cork, in a dissecting dish full of water. The cork must be sheet cork, weighted down with lead so as to sink in the water. 
Stick one pin through the tip of the abdomen, and another through the femur of each hind leg. Cut with scissors just through the body wall, along each side of the body from the tip of the abdomen to the head. With forceps, lift the flap between the cuts, scraping away the tissues below it with the scalpel. Study.

2. Find the air sacs along each side. How many?

3. Find the air tubes, or tracheæ. Trace them to the spiracles.

If the grasshopper has been preserved in alcohol, the tracheæ and air sacs will not show very plain; but in a freshly killed specimen they will be filled with air and will show as silvery white tubes.

4. Find the large muscles in the thorax that move the wings.

5. If your specimen is a female, see the ovaries and the eggs. How many eggs? How arranged? What shape?

6. Trace the oviduct from the ovaries to the ovipositor.

7. Thrust a blunt probe into the mouth. It passes through the osophagus into the crop.

8. Find some double cone-shaped pouches just behind the crop. These are the gastric cæca. How many?

9. Find the stomach.

10. Trace the intestine.

11. Draw the alimentary canal, showing esophagus, crop, cæca, stomach, and intestine.

12. Notice in the body many small red threads. These are the urinary tubules. They are excretory organs.

13. Carefully remove the digestive organs and look for the nervous system lying along the floor of the abdomen. Trace it through the thorax.

14. Is the nerve cord double or single? Find little knots (ganglia) on the nerve cord. How many ganglia in the abdomen? How many in the thorax? 
15. See the nerves branching off from the ganglia.

16. In the head, between the compound eyes, find the supra-cosophageal ganglion. Find the optic nerves leading from this to the eyes. Trace the two parts of the nerve cord from the supra-cesophageal ganglion around the oesophagus to the infra-œsophageal ganglion below the oesophagus.

17. Make a complete drawing of the nervous system.

18. What drawings have you made?

19. Copy the following words into your notebook; spell; pronounce. Tell to what each term is applied.

$\infty$ sǒph'a gus

găs'trie çæ'ea

in tès'tine găn'gli on

trā'ehe

œ so phăğg eal $\bar{o}^{\prime}$ va ry

$\bar{o}^{\prime}$ vi duct

ù'ri na ry

Questions to be Answered by Observing a Live Grasshopper.

1. Watch the breathing. What movement is visible in the abdomen?

2. Observe a spiracle. Does it open and shut?

3. In what order are the legs moved while walking?

4. Why does the grasshopper spit out " molasses" ?

5. Does the grasshopper have as good means of breathing as man? Of locomotion? Of seeing?

\section{To the Teacher.}

The purpose of this study of the grasshopper is to train the pupil to get knowledge at first hand and to get clear ideas of the object studied, to give him practice in concrete analysis, and to train him to use the mind in its power of abstraction. This purpose will be defeated if he be told too much, if he be sent to books of reference, or be allowed to find an answer to the questions proposed by asking another person. It is not the knowledge gained that is of value, but the power acquired in gaining the knowledge. If the knowledge be acquired in the wrong way, there can be but little gain in power. 


\section{Microscopic Objects.}

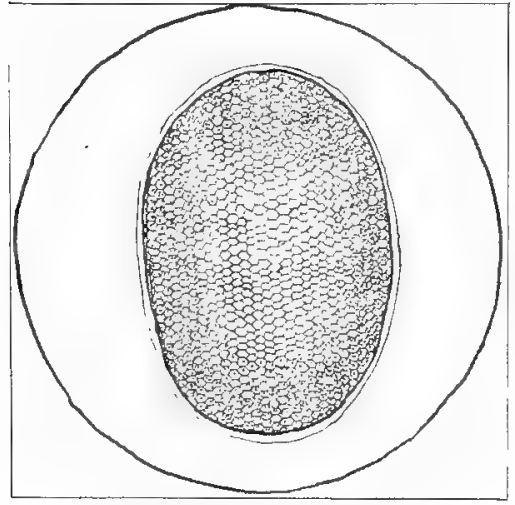

When viewed with a microscope, the surfice of a compound eye is seen to be marked off into little spaces called facets. These facets are six sided, crowded closely together, and each eye contains from six to ten thousand facets. Each facet seems in some way to represent a simple eye.

TER COMPUUND ETE.

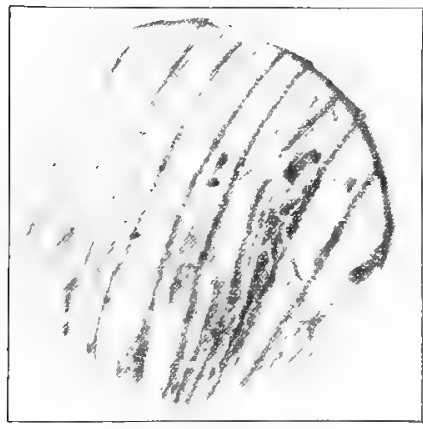

CROP OF GRASSHOPPER.

If the crop of a grasshopper be split open, it will be seen to be composed of two layers. The inner layer has many sharp-pointed teeth upon its surface, arranged in rows or groups. The teeth aid in tearing the food to pieces.

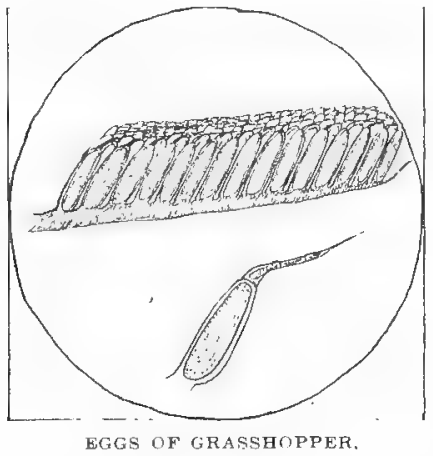

Each egg is seen to be enclosed in a sac, the mouth of which opens into the oviduct. In the smaller end or tip of the sac will be found two or three immature eggs in various stages of development, 


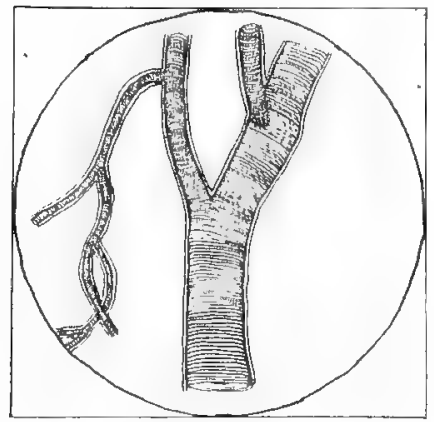

AIR TUBHS (TRACBFA) OF GRASSHOPPER.

The tracheæ brancl freely and ramify throughout all parts of the body. Each trachea appears to be composed of a fine thread wound spirally around the tube.

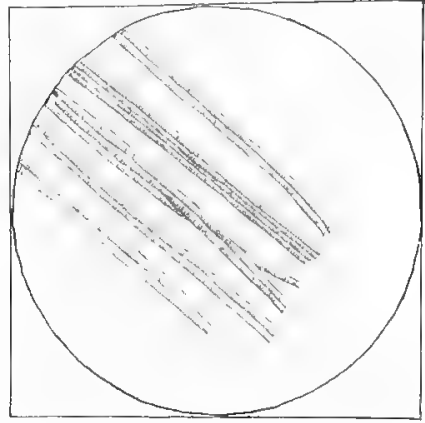

MUSCLE FIIBRS FRAM THORAX OH (IRASSHUPPEIR.

The muscle is composed of slender fibers, each of which is marked by the transterse stria, which are al ways considered indicative of voluntary muscle.

\section{The Young Grasslopper.} old one.

1. Examine the young grasshopper as you did the

2. Notice the body divisions, head, antennie, eyes, ocelli, labrum, mandibles, labium, labial palpi, maxilla, maxillary palpi, thorax, wings, legs, abdomen, spiracles, and ears.

3. Find, especially, differences in the eyes, wings, and legs.

\section{Suggested Wxamination Questions on the Grasshopper.}

1. How many body segments in the body of a grasshopper?

2. Name all the mouth parts of a grasshopper.

3. Draw the leg, naming all parts. 
4. State differences between the fore and the hind wing.

5. How many pairs of spiracles on the body of the grasshopper? On what segments do they occur?

6. Name all parts of the digestive system.

7. Where are the ears situated?

8. Describe and draw the nervous system.

9. Describe the position and structure of the antennæ.

10. How many eyes has the grasshopper? Where are they located with reference to each other?

\section{Review Questions on the Grasshopper.}

1. How many segments in the abdomen?

2. How many spiracles on the abdomen?

3. What are the parts of a single segment?

4. How many segments in the thorax?

5. What appendages does each segment bear?

6. State the differences between the fore and the hind wing.

7. Name all the parts of the leg.

8. Where is the ear?

9. How many segments in the tarsus?

10. Describe the eyes.

11. Describe the antennæ.

12. Name all the mouth parts.

13. How many pairs of paired appendages on the head? What are they?

14. How many head segments do they represent?

15. How many segments in the entire body of the grasshopper.

16. What constitutes the skeleton?

17. In what respects does the body of a grasshopper differ from the body of a man?

18. Name all the parts of the digestive system.

19. Where is the crop? 
20. Describe the teeth in the crop.

21. How many gastric cæca? What is their use?

22. Is the intestine straight?

23. Where are the ovaries?

24. What shape are the eggs?

25. In what are the eggs enclosed?

26. How many eggs did you find in the ovary?

27. Did you see any immature eggs?

28. How do the eggs escape from the body?

29. What is the oviduct?

30. What is the ovipositor? How is it used?

31. What are the urinary tubules?

32. What are the internal breathing organs?

33. Describe the structure of an air tube.

34. From what do the air tubes run?

35. Describe the branching of an air tube.

36 . To what parts of the body do the air tubes run?

37. Is the grasshopper's system of breathing as good as ours?

38. Where is the nervous system?

39. Of what does the nervous system consist?

40. Is the nerve cord double or single?

41. How many ganglia in the body?

42. Where are the largest muscles?

\section{Additional Facts About the Grasshopper.}

The skeleton of the grasshopper consists of the hard parts of the body, and these are on the outside. It is therefore called an exoskeleton. It is composed of a substance somewhat like horn, which is called chitin. The teeth in the crop are composed of the same material. The hard parts of the body are on the outside, and growth cannot take place gradually. Increase in size of the body cannot increase the size of the hard skeleton. So, when a grasshopper. is growing up to full size, it sheds its skeleton four or 
five times. This process is called molting, and is quite easily observed. The grasshopper hangs head downward from a twig, post, or some other support. The skin, or skeleton, splits open on the back, and the grasshopper comes out, leaving the old skeleton of every part of its body; eyes, antennæ, legs, etc. The process of molting requires about half an hour, and after the process the legs are very weak and the body very soft. For a day or two the grasshopper grows rapidly, and then ceases to grow until the next molt.

When a grasshopper is hatched from the egg, it resembles somewhat the old one. In all its molting, it still resembles the mature grasshopper. On this account it is said to have an incomplete or direct metamorphosis.

The metamorphosis of an insect is the seriess of changes that it undergoes from the egg to the mature form.

The grasshopper breathes through spiracles which open in to the tracheæ, or air tubes through which air is conveyed to all parts of the body. There is, then, no need for blood to serve as a conveyer of air to the tissues of the body, nor to carry carbon dioxide away from the tissues. So we find that the blood in a grasshopper is very small in quantity and is white in color. It has no red corpuscles. There is a slender tube lying along the back which contains some blood and is called a heart. It is rather difficult to discover in a dead specimen.

Each facet of the compound eye probably represents in some way a single eye. If all the facets of the eye were covered up except one, the grasshopper could still see with that one. The shape of the compound eye is such that some of the facets are directed upward, some downward, some forward, and some backward. It would seem that the grasshopper is well provided with means for seeing, but it is very doubtful 
whether a grasshopper can see an object or not with a compound eye. It can discern color and movement very well, but these eyes can probably not define an object to its sight. The ocelli probably enable the grasshopper to see an object, but it must be one that is very close to the eye if it can be seen at all. It must be within half an inch or less of the eye.

Without any doubt, the grasshopper can feel. The antennæ and palpi are usually regarded as feeling organs. It seems certain that the grasshopper can hear, for it can make a noise, and it has an organ on the abdomen that seems to have the structure of an ear. An insect that makes a noise must be supposed to have some means of hearing similar noises that other insects of the same kind make. We judge from the food that the grasshopper chooses that it can taste. Whether it tastes with the tongue or palpi we are unable to say. It is probable that the sense of smell is very different from ours. Our sense of smell is located in the air passages of the nose. We should expect to find the grasshopper's nerves of smell reaching the surface at the spiracles, but such does not seem to be the case. It may be that the sense of smell, or what corresponds to it, is located at the base of the antennæ.

The food of the grasshopper consists of the leaves of plants. The extent of injury grasshoppers do to crops depends entirely upon their numbers. In 1874 and 1875 grasshoppers were so numerous that they destroyed all the crops in the greater part of the states of Kansas and Nebraska, and in some parts of Missouri, Iowa, and adjoining states. The grasshopper that did this injury is the kind known as Melanoplus spretus. It is somewhat like the locust mentioned in the Bible.

Grasshoppers are prevented from becoming too numerous by rarious enemies, or checks. One enemy of the grasshopper is the silky locust mite. It is a very bright red, eight-legged creature, and is often found 
clinging to the bodies of either the young or the old grasshoppers. In the early spring, before grasshopper eggs are hatched, this mite finds the holes where eggs of grasshoppers have been laid, and eats the eggs. Hair worms are sometimes found in the intestines of grasshoppers, and so, also, are the larva of some Tachina flies. Such animals as the silky locust mite, hair worm, and Tachina flies, that live upon the bodies of other living animals, are called parasites. The weather, no doubt, in some seasons, kills many grasshoppers, and they are subject, also, to contagious fungous diseases. It usually happens that after a season in which grasshopper's have been very numerous, the following season will have very few.

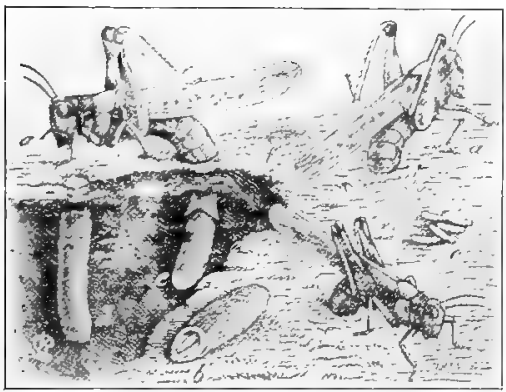

GRASSHOPPERS LATING EGGS (AFTER RILEY)

The eggs of the grasshopper are laid in holes in the ground. The female grasshopper digs with her ovipositor a hole the length of the abdomen, and deposits in it a mass of eggs, forty or fifty in a bunch.

$a$, grasshoppers ovipositing; $b$, egg case extracted; $c$, eggs; $d$, egg catse in the ground; $c$, egg case in process of deposition; $f$, hole in which eggs have been laid.

In general, the grasshopper has a color that renders it inconspicuous in the place where it usually lives. Some grasshoppers, that like to live in the roads, are dust-colored. Others, that are usually found annong dried grass, are mottled brown. Because the grasshopper is generally concealed or rendered inconspicuous by its color, it is said to be protectively colored.

Some grasshoppers live through the winter, but most of them live not more than three months. They die of old age before winter comes. 


\section{Names.}

The grasshoppers that you have studied are individuals. Individuals that are much alike constitute a species. Species that are much alike constitute a genus. Genera that are much alike constitute a family.

We may make up a table like this :-

Individual.

$$
\begin{aligned}
& \text { Species. } \\
& \text { Genus. } \\
& \text { Family. }
\end{aligned}
$$

All grasshoppers belong to the family Acrididæ.

In order that we shall know what kind of grasshopper or other animal or plant we are talking about, they have been given names. A few of the most important rules for naming are here stated.

I. The name of every animal or plant consists of two parts, the name of the genus and the name of the species. The name of the genus should always be written first, and should always begin with a capital letter. The name of the species should usually begin with a small letter.

II. The name of every animal or plant should be Latin, or have the Latin form. When this system of naming was proposed, all scholars knew Latin. It would be impossible for all scientific men to agree upon German or English or French, or any other living language.

III. The name that is first given to an animal or plant is the one by which it shall be known, if that name is tenable. A name is not tenable if the same name has been previously applied to some other animal or plant. Usually, the name of the man who first described the insect and gave it its name is written after the name. This is called the Authority and is often quite necessary to distinguish the insect. 


\section{CHAPTER II.}

\section{THE CRICKET.}

1. Examine the cricket as you did the grasshopper. See the body divisions, head, antennæ, eyes, ocelli, labrum, labium, labial palpi, mandibles, maxillæ, maxillary palpi, thorax, wings, legs, coxa, femur, tibia, tarsus, abdomen, and spiracles.

2. Find the ear, which is on the tibia of the fore leg.

3 . Find the stylets, which are at the end of the. abdomen.

4. If your specimen is a female, notice the long, slender ovipositor, between the stylets. Of how many parts is it composed? Why is this ovipositor so different from that of the grasshopper?

5. Study the spiracles. How many?

6. If your specimen is a male, look on the under side of the outer wing for a large cross-vein. Can you find teeth upon it? With this the cricket makes his chirping noise.

7. Can a cricket fly? Some kinds have the inner wings very small.

\section{Additional Facts About the Cricket.}

The cricket is black, or dark brown, and lives in dark places, coming out only at night. It is therefore protectively colored. The antenna are very much longer and more slender than are the antennæ of the grasshopper, and probably in its dark crevice the cricket must depend upon his sense of feeling more 
than the grasshopper does. The stylets, also, are organs for feeling.

The ovipositor is very long and slender. The eggs are laid in a crevice or hole already provided. The cricket does not make the hole.

The cricket belongs to the family Gryllidæ. The family is named from the genus Gryllus, of which the two most common species are abbreviatus, with short inner wings, and luctuosus, with long wings.

\section{Microscopic Objects.}

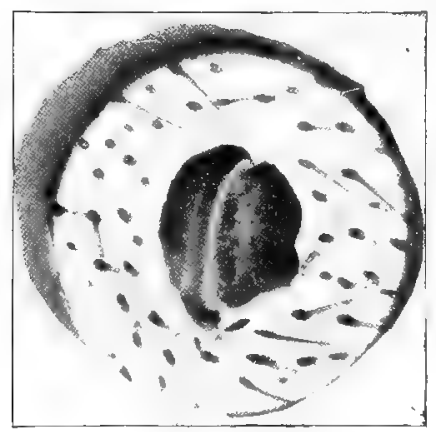

SPIHACLE UF CRIC'KET.

Behind the stomach will be found a small spherical body, the gizzard. This is composed of two layers, the inner one of which has six series of leaflike chitinous teeth.
The edges of the spiracles are seen to be composed of two lips hardened with chitin. From the edges of the lips, fine hairs grow inward, which serve to prevent dust or other foreign particles entering the tracher.

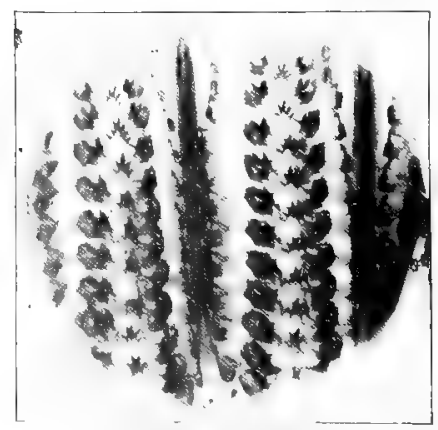

GIYZARD UF CRICKET. 


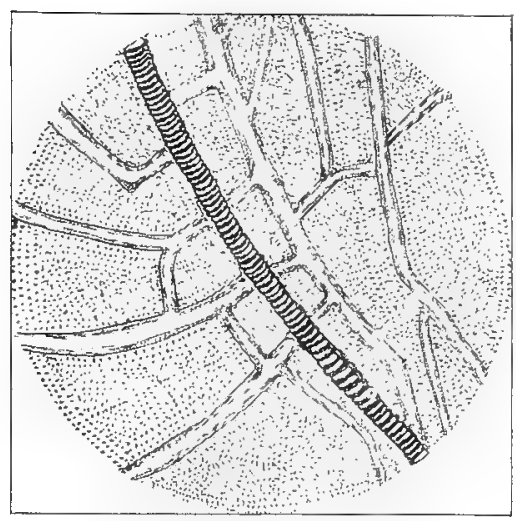

WING FILE OF MALE CRICKET.
The cross-vein on the outer wing of the male cricket is provided with a set of teeth, which, by rub. bing over the vein of the other wing, produces the cricket's chirp.

\section{THE KATYDID.}

1. Examine the katydid as you did the grasshopper. See all the organs.

2. Where is the ear?

3. Find the apparatus with which he makes the sound "Katydid."

4. Find the ovipositor. Is it straight or curved? of how many parts is it composed?

\section{Additional Facts.}

The katydids are light green colored, like the leaves among which they live. They are protectively colored. The legs are more slender, and the whole body is more loosely joined together than that of the grasshopper. This may be associated with the fact that the katydid does not fly so far nor so rapidly as the grasshopper does.

The eggs of the katydid are laid upon or in the edges of leaves, or sometimes between the bark and stem of a shrub or twig.

The katydid belongs to the family Locustidie. 


\section{THE WALKING STICK.}

1. Find the parts on the walking stick that you found on the grasshopper. Are any parts missing?

2. Can you find any ears? Has it any means of making a noise?

3. The abdomen of the female is thicker than that of the male. The male has a spine on the femur of the hind leg that is much larger than the spine on the female. Is your specimen a male or a female?

4. What enables the walking stick to escape from its enemies?

\section{Additional Facts.}

The walking stick represents the family Phasmidæ. The only species common throughout the United States is Diapheromera femorata.

The walking stick feeds on the leaves of trees and bushes. It resembles the twigs so closely that when resting upon the bushes it is very difficult to see. This resemblance of an animal to some other object is called protective resemblance.

Make a table after the following form, showing the differences between the grasshopper, cricket, katydid, and walking stick.

\begin{tabular}{|c|c|c|c|c|}
\hline & $\begin{array}{l}\text { Grass- } \\
\text { hopper. } \\
\text { Acridida. }\end{array}$ & $\begin{array}{l}\text { Cricket. } \\
\text { Gryllidie. }\end{array}$ & $\begin{array}{l}\text { Katydid. } \\
\text { Locustidie. }\end{array}$ & $\begin{array}{c}\text { Walling } \\
\text { Stick. } \\
\text { Phasmida. }\end{array}$ \\
\hline Antennæ $\ldots \ldots \ldots$ & 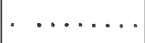 & $\cdots$ & & $\theta^{\circ}$ \\
\hline 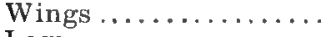 & $\ldots \ldots$ & $\ldots \ldots \ldots$ & $\ldots \ldots \ldots$ & $\ldots \ldots \ldots$ \\
\hline Legs.... $\quad \ldots \ldots \ldots$ & $\ldots \ldots \ldots$ & $\ldots \ldots \ldots$ & $\ldots \ldots \ldots$ & $\ldots \ldots$ \\
\hline 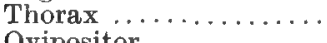 & $\ldots \ldots \ldots$ & $\ldots \ldots \ldots$ & $\ldots \ldots \ldots$ & $\ldots \ldots \ldots$ \\
\hline $\begin{array}{l}\text { Ovipositor. . . . . . . . . . } \\
\text { Stylets. }\end{array}$ & $\cdots \cdots \cdots$ & $\cdots \cdots \cdots$ & $\cdots \cdots$ & $\ldots \ldots \ldots$ \\
\hline 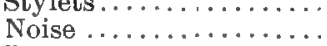 & $\begin{array}{l}\cdots \\
\ldots \ldots\end{array} \ldots$ & $\cdots \cdots$ & $\cdots \cdots$ & $\begin{array}{ll}\cdots & \cdots \\
\cdots & \ldots\end{array}$ \\
\hline $\operatorname{Ear} \ldots \ldots \ldots \ldots \ldots$ & $\ldots \ldots \ldots$ & $\ldots \ldots \ldots$ & $\ldots \ldots \ldots$ & $\ldots \ldots$ \\
\hline Locomotion ........... & $\ldots \ldots \ldots$ & $\ldots \ldots \ldots$ & $\ldots \ldots \ldots$ & $\ldots \ldots \ldots$ \\
\hline Color. $\ldots \ldots \ldots \ldots \ldots \ldots$ & $\ldots \ldots \ldots$ & $\ldots \ldots \ldots$ & $\ldots \ldots \ldots$ & $\ldots \ldots \ldots$ \\
\hline
\end{tabular}


Make a table in the following form, stating the resemblances concerning the eyes, antennæ, etc., of the grasshopper, cricket, katydid, and walking stick.

Grasshopper
Cricket
Katydid
Walking Stick
all have one pair of antennæ
jaws move sideways
have three body divisions
three thoracic segments
two pairs of wings (except the walking stick)
three pairs of legs
segmented abdomen
all lay eggs
jointed appendages
incomplete metamorphosis
external chitinous skeleton
white blood
double nerve cord and ganglia
breathe by spiracles

There are two other families which are very similar to the insects previously studied. These are the Blattidæ, represented by the Cockroach, and the Mantidæ, represented by the praying Mantis. All these families are so much alike that they are grouped together, and the group is called an order. The name of the order is Orthoptera. The name means straight wings, and the order was named from the outer wings of the grasshopper. The name is not a good one, for the walking stick has no wings at all, but is so much like the grasshopper in other respects that it must be put into the same order. The Orthoptera all have biting mouth parts and incomplete metamorphosis. 


\section{CHAPTER III.}

\section{THE BUTTERFLY.}

Any butterfly will do for this study, but the large, brownish red butterfly with black wing veins (Anosia plexippus) is a good one.

1. Find the body divisions.

2. On the head, find the eyes, labial palpi, antennæ, and sucking tube. To what organs on the grasshopper does the sucking tube correspond? Are there any other mouth parts? Are there ocelli?

3. Study the legs. Are all alike? Identify all the parts. Of what use are the legs?

4. Study the wings. To what is each attached? How are they held when at rest? Which side of the wing is exposed to view when the butterfly is resting?

5. Scrape some dust off the wings. This dust consists of scales which cover the wings and the body. Examine a piece of the wing with your lens. The scales may be seen overlapping each other like the shingles on a roof.

6 . At the base of the fore wing, find an appendage covered with scales or hair. This is the patagium, or shoulder lapper.

7. Make a drawing of the veins of the wing. The central cell, from which several veins seem to start, is called the discal cell.

8. How many segments in the abdomen? Are there spiracles? How many? 


\section{THE CATERPILLAR.}

1. Can you distinguish any body divisions? Is the head distinguishable from the rest of the body?

2. Are there antennæ on the head? Eyes? Mandibles? Palpi?

3. How many segments behind the head? Are there spiracles? How many?

4. How many legs do you find? What difference in the legs?

5. The kind of legs in front are the true legs. On what segments are they borne?

6. The kind of legs behind are false legs, or prolegs. On what segments are they borne? Examine carefully the tip of each of the prolegs.

7. What changes would have to be made in the body of a caterpillar in order to make a butterfly out of it?

8. Describe the color, hairs, and anything else you see on the caterpillar.

9. The caterpillar is the larva of a butterfly or of a moth.

10. The butterfly or the moth has an indirect or complete metamorphosis.

\section{THE CHRYSALIS AND COCOON.}

1. If the chrysalis and cocoon of the large moth, Samia cecropia, can be obtained, it will serve for this study very well. If not, any other chrysalis will do.

2. Study the shape and mode of attachment of the cocoon. Draw.

3. Do you find a hole at one end of the cocoon? Toward which end of the twig is the hole?

4. Cut open the cocoon along one side. Of how many layers is it composed? How do the layers differ? 
5. The material of which the cocoon is composed is silk. Silk originates as a liquid in some glands in the caterpillar, which open near the maxillæ. It is drawn out in a fine thread which hardens when exposed to the air.

6. Study the chrysalis. Note its size and shape. Draw.

7. Can you distinguish body divisions? Abdominal segments? Spiracles? Wings? Antennæ? Sucking tube?

8. Perhaps in the cocoon you can find the cast-off skin of the caterpillar.

9. The chrysalis is the pupa of a butterfly or of a moth. Butterflies do not make cocoons.

\section{THE MOTH.}

1. Study a moth as you did a butterfly. Note all the differences you see in the antennæ, size of the body, position of the wings when at rest.

2. Make a table of differences between a butterfly and a moth, according to the following form :-

\begin{tabular}{|c|c|c|}
\hline & BUTTERFLY. & мотн. \\
\hline Antennæ. & $\ldots \ldots \ldots \ldots$ & $\cdots$ \\
\hline Thickness of the body . ...... & $\ldots \ldots \ldots$ & ... \\
\hline Position of the wings at rest. & $\ldots \ldots \ldots$ & $\cdots \cdots \cdots$ \\
\hline 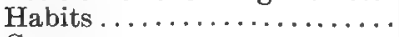 & diurnal & nocturnal \\
\hline 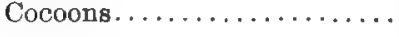 & $\ldots \ldots \ldots \ldots \ldots$ & $\ldots \ldots \ldots$ \\
\hline
\end{tabular}

\section{Additional Facts.}

In the growth of a butterfly, or of a moth, there are four stages: egg, caterpillar, chrysalis, and butterfly or moth. The caterpillar is called the larva; the chrysalis is called the pupa; and the mature butterfly or moth is called the imago. This kind of metamor- 
phosis is called a complete metamorphosis, for the stages are very distinct from each other. It is also called indirect, because the butterfy or 1 noth reaches its mature form by a roundabout way, through the several stages.

\section{Microsenpic Object.}

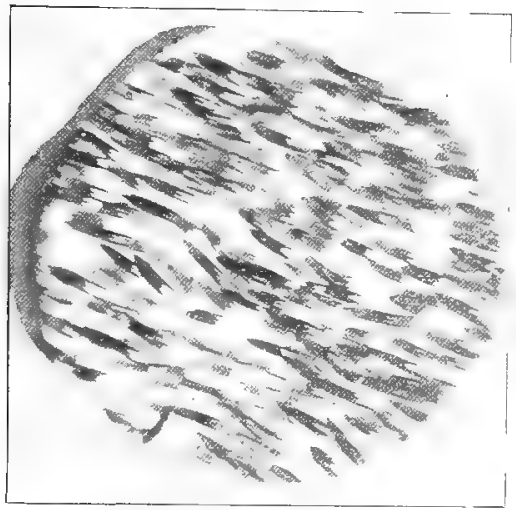

SCALES OF CECRUPIA MOTH.
The color of the wings depends upon the color of the scales. Scales of several different shapes may be found upon the wing of a butterny.

The butterfly has sucking mouth parts. The sucking tube is composed of two parts which are homologous to the maxillæe of the grasshopper. Two organs are said to be homologous when they bear the same relation to their respective bodies, no matter how different the organs may he in appearance or use. In this case, one pair of organs on the grasshopper has been developed as a pair of jaws, and we call them maxillæ. The same organs have been developed on the butterfly as a sucking tube. It is this sameness that constitutes the homology. We know that two organs are homologous by their having the same position or the same structure.

The labial palpi and the sucking tube are the only mouth parts the butterfly has. Indications of the 
other mouth parts may be found on the butterfly, but these organs never become functional in the imago. They are said to be vestigial. In the Samia cecropia, and other moths of the family Bombycidx, all the mouth parts are rudimentary or vestigial. They are unable to eat anything while in the imago state. They do not live; they die. The Samia cecropia will die within about five days after it comes from the cocoon. Its eating has all been done by the caterpillar. The only function of the imago is to lay eggs and reproduce the species. We shall find many examples of vestigial organs. They seem to be organs which are retrograding, or having once been functional in the history of the species, have ceased to be so.

Anosia plexippus furnishes a good example of the form of protective coloration that is called mimicry. The butterfly itself is not concealed by its color. It is very conspicuous. But it is quite distasteful to birds and other insect-eating animals. Its conspicuousness is an advantage to it, for when the birds know what it is they will let it alone.

But there is another butterfly, Basilarchia archippus, which closely resembles the plexippus in color. It can be distinguished by a black streak across the hind wing. This butterfly is not at all distasteful to birds; but birds, being deceived by its resemblance to plexippus, seldom catch it. The archippus is said to resemble, or imitate, or mimic the plexippus. Structurally, the two butterffies are very different, and no other species of the genus Basilarchia is colored like this one. Numerous examples of mimicry may be found among insects.

All silk of commerce is produced by the caterpillar of the silk worm (Bombyx mori). The cocoon of the Samia cecropia is larger and contains more silk, but it cannot be reeled, in consequence of being fastened to a twig or some other solid support. 
Among the moths and butterflies are found some very injurious insects. The injuries are all done by the larvæ. Among them we may mention the clothes moth, cotton worm, bollworm, tobacco moth, tomato moth, tent caterpillar, codling moth, and gypsy moth. The codling moth is the moth whose larva appears as a white worm in the core of an apple. The gypsy moth is very destructive to forest trees in Massachusetts.

Butterflies and moths belong to the order Lepidoptera. The name means scaly wings. All the Lepidoptera have sucking mouth parts and complete metamorphosis.

\section{THE BEETLE.}

1. Identify the body divisions.

2. Find the eyes, antennæ, labium, labial palpi, mandibles.

3. Identify the parts of the leg. An extra joint, between the coxa and the femur, will be seen. This is called the trochanter. How many segments in the tarsus? Do all the tarsi have the same number?

4. Study the wing. How does the fore wing differ from the hind wing? The fore wings are here called elytra. What is their use?

5. How does the hind wing fold up?

6. Draw the wings, both open and closed.

7. How many segments in the abdomen? Do you find spiracles? How many?

8. Make a drawing of the larva of the beetle. Does the beetle have a complete or an incomplete metamorphosis?

9. Draw a full page ventral view of a beetle, showing all the parts.

\section{Additional Facts.}

The beetle belongs to the order Coleoptera. This is one of the largest orders of insects. The name 
means sheath "wings, and it is so called from the character of the fore wings. There are probably 25,000 species of beetles. All have biting mouth parts and complete metamorphosis.

Among the beetles are many injurious insects. We may mention the wire worms, which are larvæ of click beetles, and the curculios, the wood borer, the carpet beetle, and the Dermestids, or fur beetles.

Beetles are found almost everywhere. Some live in the water, some in the ground, some in decayed wood, and some on leaves. Some are predaceous and prey upon other insects.

\section{THE GIANT WATER BUG.}

1. Find the body divisions.

2. Find the compound eyes. Are there ocelli?

3. Find the antennæ. Draw.

4. Find the sucking tube. Is it segmented? How many segments? To what is it homologous?

5. In a groove on the upper side of the sucking tube, find a hair-like organ. Of how many parts is it composed? To what must these parts be homologous?

6 . Find a pointed flap lying on top of the groove which conceals the hair-like organ, or punctorial bristle. From its position, to what must it be homologous?

7. Study the wings. What peculiarity has the front pair? Draw.

8. Notice how the wings lock together when folded on the back. Find the little knob fitting into a groove on the edge of the thorax, that holds the wings down to the body. See how the fore and hind wings are held together when the wings are spread. Draw.

9. Identify the parts of the legs. How does the lind leg differ from the fore leg? Is the femur of the fore leg grooved or smooth? 
10. What peculiarity has the prothorax?

11. Study the abdomen. How many segments? Do you find any spiracles? Where?

12. Cut off the wings and find the nerve cord. How does the nervous system differ from that of the grasshopper?

13. Juok at the larva and say whether the giant water bug has a direct or an indirect metamorphosis.

\section{Additional Facts About the Giant Water Bug.}

The giant water bug lives in ponds, and flies around at night. It is attracted in great numbers to - electric lights, and is sometimes called the electriclight bug. There are two kinds, the Belostoma americanum, in which the femur of the fore leg is grooved to receive the tibia, and Benacus griseus, in which the front femur is not grooved.

The giant water bug is quite destructive to minnows and young fish, piercing them with its beak. Parasites are frequently found on giant water bugs, one of the most common forms being Hydrachna belostomæ.

A smaller insect, Zaitha fluminea, much like the giant water bug, and living in the same situations, may be used for this study. The squash bug is also very good.

\section{THE CICADA.}

1. Identify the body divisions.

2. Study the eyes, ocelli, antennæ.

3. Examine the mouth parts. See the punctorial bristle. Of how many parts is it composed?

4. Notice the wings. How do they differ from the wings of the giant water bug?

5. Study the legs. How does the first pair differ from the other legs? 
6. If your specimen is a male, note the air sac in each side of the dorsal surface of the abdomen. See the thin plates on the ventral side of the abdomen, which are used in producing the sound.

7. If your specimen is a female, study the ovipositor carefully.

8. Draw the entire insect.

\section{Additional Facts About the Cicada.}

Either the seventeen year Cicada, or the common harvest fly, may be used in making this study. There are very few insects that live longer than the seventeen year cicada. It lives under the ground as a larva or pupa for seventeen years, then suddenly makes its appearance in May or June, transforms to the imago stage, lives for three or four weeks, lays its eggs, and dies. The eggs are laid in a groove cut by the female in the young twigs of trees. The eggs hatch and the larvæ drop to the ground, in which they disappear and are seen no more for seventeen years. The trigs in which the eggs are laid frequently die from the injury received, and as a result much damage is done, especially to fruit trees. There are in this country about twenty-three broods of the seventeen year locusts, so that at least one brood is likely to appear somewhere in the United States every year. There is also a thirteen-year form, of which several small broods exist in the United States. The common harvest fly, or dry fly, Cicada pruinosa, lives only two years.

The Cicadas are noticeable for the very loud noise they make. Under ordinary conditions, the song of a single Cicada can be heard for at least a mile.

The Cicada and the giant water bug represent two divisions of the order Hemiptera. All the insects of this order have the sucking mouth parts and incom- 
plete metamorphosis. The pupa of the Cicada is very unlike the imago, but as is the case with the pupa of other Hemiptera, it has no period of inactivity.

The name Hemiptera means half wings, and refers to the texture of the different parts of the fore wings on the giant water bug, or still better, the squash bug. The name for the order is not a good one, for some of the insects of this order have no wings; in some, as in the Cicada, the wings are uniform in texture throughout. The order is now commonly separated into two divisions: Heteroptera, represented by the giant water bug; and Homoptera, represented by the Cicada.

Among the Hemiptera we find some of the strangest forms known among insects. Especially is this true of the tree hoppers, the wheel bug, and the water scorpion.

We find also among the Hemiptera some of the most destructive insects. In some years the chinch bug has destroyed crops, principally of wheat and corn, whose value would amount to many millions of dollars. It produces the injury by piercing the stalk of the plant with the beak and sucking out the juices.

Among the plant lice, especially, we find examples of a method of reproduction that is quite unusual among animals so highly organized. In nearly all animals, the individuals are male and female. Ordinarily, the eggs of the female will not hatch, or produce young, unless they are fertilized by the male. But we find that several generations of plant lice may be produced in one season without fertilization by any male. This process of reproduction without fertilization by a male is called Parthenogenesis. Generally, at the close of a summer a sexual generation is produced and fertilization occurs in the ordinary way. 


\section{THE HOUNL FIN}

1. Identify the hody divisions.

2. On the head, find the eyes, ocelli, antennx. Draw the antenna.

3. Fxamine the so-called "tongue," or proboscis. Inentify the palpi, the labella, or large flap at the tip, the sheath, and the lancets within the sheath.

4. Identify the segments of the log. Study the foot carefully. Draw.

5. Find the wings. How many? See the backward 'xtension of the wing, which is called the alula, or winglet. Study and draw the wing carefully.

6. Back of the wing, find on each side a knob borne on a stalk. These knobs are known as the balancers. Judering from their position, to what are they homologous?

7. Are there spiracles on the thorax?

8. How many segments has the abdomen? How many spiracles do you find?

9. 'The larva is called a maggot. Where can it be found? What kind of metamorphosis has the fly?

\section{Miromseopuce Ol,jecets.}

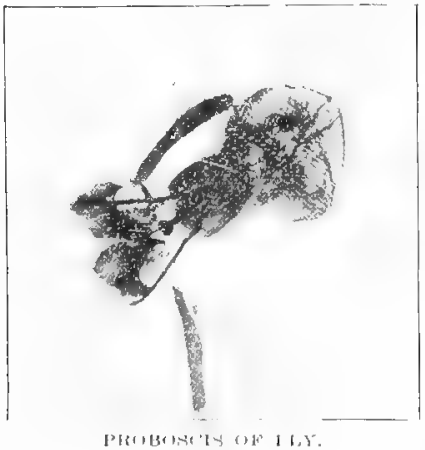

With the exception of the max illary palpi, the mouth parts of the fly are modified into a proboscis which constitutes a sucoking and piercing organ. When not in use, it is folder up under the heal. 


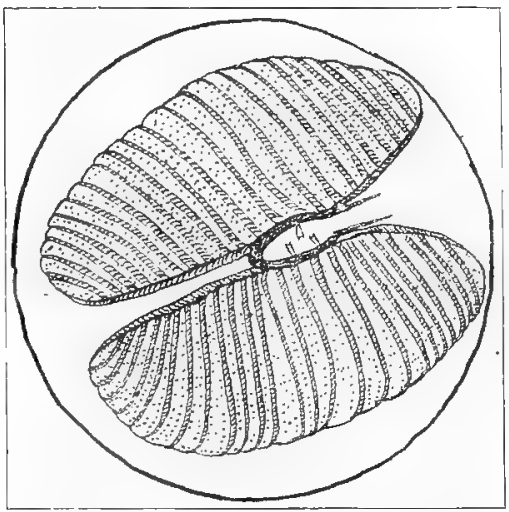

The labellse consist of a mass of tissue through which run spirally-coiled rods radiating from a horseshoe-shaped rin. The labella are probably homologous to the labial palpi, and the palpi are maxillary p.lpi.

LABELLA OF HOUSE FLY'S PROBOSCIS.

The horseshoe-shaped rim seems to constitute the end of the sheath, and through its opening the lancets work. The sheath is homologuns to the labium.

The lancets are enclosed in the sheath, and are homologous to the maxillæe. They are moved up and down by two chitinous rods to which muscles are attached.

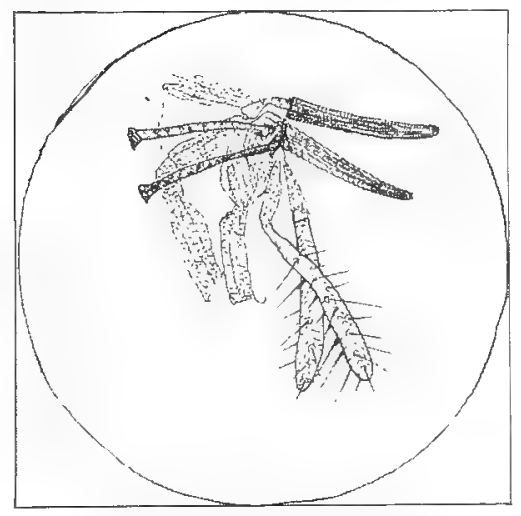

I.ANCETS AND PALPI OF HOUSE FLY. (Labella removed.)

The lancets pierce the skin of an animal, and the labellæ and sheath constitute a sucking organ by which the blood is drawn from the puncture. 


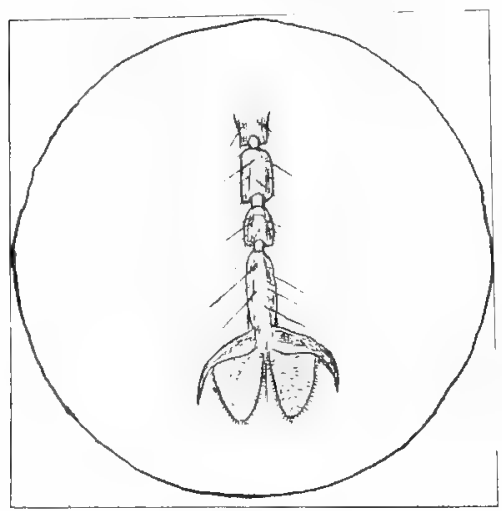

FOOT OF FLY.
The foot consists of two pads thickly beset with minute lairs, and two hooks. No thoroughly satisfactory explanation has been given of how a fly sticks to a vertical surface of glass.

The wing of any insect is comprosed of veins, and spaces boumled by reins. These spares are called cells. The large vein forming the front margin of the wing is called the costal vein. The vein marked 1 is the auxiliary vein; $2,3,4,5$, and 6 are the first, second, third, fourth, and fifth longitudinal veins. The short crossvein between 4 and 5 is the midulle trimsverse vein: the slort vein between 5 and 6 is the hinder transverse

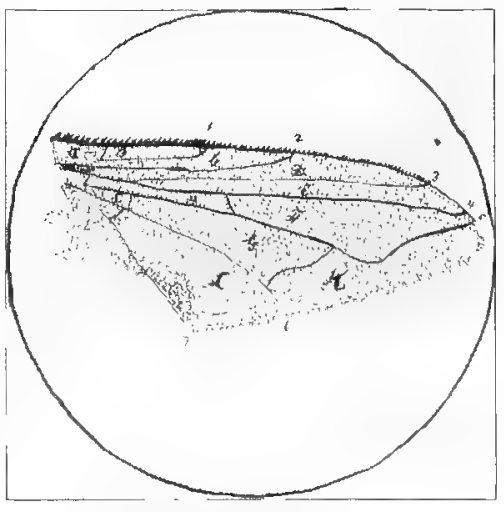

WING OF FLY. vein. The cells $\Lambda, B$, and $C$ are callet the first, second, and third costal cells: $D$ is the marginal rell; $\mathbf{E}$ is the sub-marginal cell; $\mathbf{F}, \mathbf{K}$, and $\mathrm{E}$ are the first, second, and third posterior cells; $G$ is the discal cell; $H$ is the first, or large, basal cell. The cells and veins of the wing are of the greatest importance in letermining the families and species of Hies. The veins of a fly s wing may be homologized with the veins of the wing of almost any other insect. 


\section{Additional Facts About Flies.}

The house fly belongs to the order Diptera. The name means two wings. The balancers represent another pair of wings in a rudimentary condition, so that flies really have the same number of wings that other insects do.

All diptera have sucking mouth parts and a complete metamorphosis, although in some members of the order, as the mosquito, the pupa is active. The larva of a fly is called a maggot. It is usually found in decaying animal matter. The mosquito lays its eggs in a bunch, which floats on the surface of the water. The egg hatches into a wiggler, which swims in the water, coming to the surface to breathe. It breathes through air tubes opening in the tail. The pupa is quite different from the larva, being a club-headed wiggler, living also in the water.

Some flies lay their eggs in the tissues of plants. The tissues then swell up around the egg, making a gall in which the larva and pupa live and undergo their transformations. These flies are called gall gnats.

Among the Diptera we find some of the most annoying insects. House flies, cow flies, bot flies, mosquitoes, and gnats, may be mentioned. The Hessian fly is exceedingly injurious to wheat, its injuries entailing a loss of many thousands of dollars every year to the farmers of the United States.

It is among the Diptera that we find the greatest number of examples of protective mimicry. There are flies that closely resemble bees, bumblebees, wasps, hornets. In many cases the resemblance is so close that experienced collectors are deceived. 


\section{THE DRAGON FIY.}

1. Identify the body divisions.

2. Study the eyes, antennæ, mandibles, maxillæ, palpi.

3. Study the wings. Note the pterostigma, near the tip, and the short cross-vein, the nodus, near the base. Count the cells and long veins. Draw.

4. Identify the parts of the leg.

5. How many segments in the abdomen? Do you find spiracles? Is there any sting?

6. Draw the larva. What kind of metamorphosis has the dragon fly?

\section{Additional Facts About the Dragon Fly.}

The dragon fly belongs to the Linnæan order Neuroptera. The name means nerve wings, and is given because of the great number of veins in the wings. In some parts of the country it is called devil's darning-needle, and is said to sew up the ears of bad children; but the devil has a proprietary interest in so many of these insects that the name is not sufficiently distinctive. 'It is also called snake doctor, from the fact that it is frequently seen hovering over the body of a dead snake, and so some people suppose it is restoring the dead snake to life. Really, it is engaged in catching the flies that are attracted to the body of the dead snake. A better name is mosquito hawk, for it is among insects what a hawk is among birds. It is probably the strongest and swiftest flier among insects. Whether it is a larva, a pupa, or an imago, it is the enemy of the mosquito.

The eggs are laid in the water, and there the dragon fly undergoes all its transformations until it reaches the imago stage. There are two kinds of dragon flies. 
One is represented by the Agrionidæ, in which the wings of the imago fold together on the back, and whose larva breathes through thin leaf-like gills at the tail. The other kind is represented by the Libellulidæ, whose wings do not fold and whose larva looks something like the larva of the giant water bug. The metamorphosis is complete, although the pupa has no resting stage.

This old order, Neuroptera of Linnæus, has been broken up into five or six orders by more recent writers. It is probably better to call the order to which the dragon fly belongs Odonata.

\section{THE BUMBLEBEE.}

1. Find the body divisions. How many segments in the abdomen? How is the abdomen joined to the thorax? Can you find any indications of extra segments on the thorax?

2. Describe and draw the eyes, ocelli, mandibles, antennæ. How many segments in the antennæ?

3. The other mouth parts are the tongue, maxillæ, and labial palpi. The tongue is the hairy organ. The labial palpi terminate in two short segments. Can you find any trace of rudimentary maxillary palpi?

4. Study the wings. See how the fore and hind wings fasten together. Examine the front edge of the hind wing for hooks that fasten the wings together.

5. Homologize the parts of the leg. See the flat "pollen basket" on the tibia of the hind leg. It is a smooth, shiny surface surrounded by stiff hairs. Is any pollen sticking to it?

6. What is honey? Where do the bees get it? What is pollen? Where obtained? For what used? What is wax? How obtained? 
7. Study the sting. The sting consists of a sheath and two lancets connected with a poison bag. At the end of the abdomen, find two palpi.

8. What is a queen? A drone? A worker? Of what use is the bumblebee's color?

\section{THE WASP, OR HORNET.}

1. Look on the wasp for the same things you found on the bumblebee, noting all differences.

2. Note, especially, the tongue. Draw.

3. Draw the larva. The pupa. What kind of metamorphosis has the wasp?

4. The sting is more easily studied than that of the bee. Draw.

5. Study and describe the wasp's nest. 'The mud dauber's nest.

\section{Microscopic Objects.}

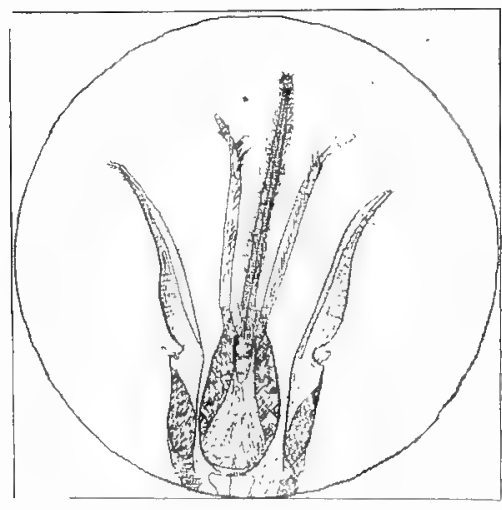

TONGUE, MAXIIL.,F, AND PAT,PI (1) HON HEY is HE.

The tongue of the bee is a slender, hairy organ. It consists of a slender cartilaginous rod and a muscular sheath. The sheath is merely folded around the rod, and is not joined at the oulges.

The lalial palpi are recognized by being segmented. Two short sesmonts at the tip, one longer segment next, and then a still longer segment constituting the principal part of the palpus.

The mixille are broader and flatter than the palpi.

Near the hend of the maxille can be seen the rudinents of the maxillary palpi. 


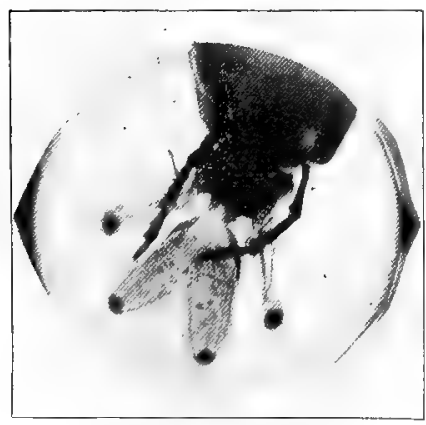

TONGUE OF WASP.

The sting of a wasp or bee consists of a shenth and two lancets. The lancets are barbed at the tips and are moved up and down by muscles in the wound that the sheath makes. Near the sting are two palpi by which the wasp is able to feel what it is stinging.

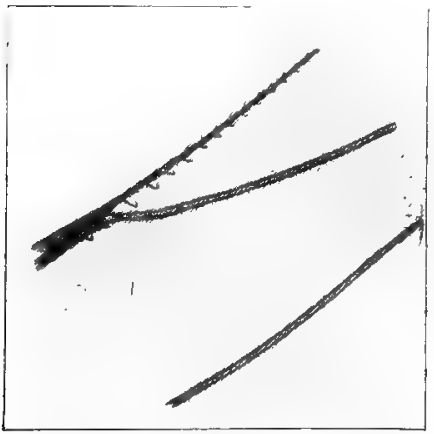

HOOKS ON HIND WING OF WASP.
The tongue of the wasp is very different from that of the bee. It is muscular, forked, and covered with hairs.

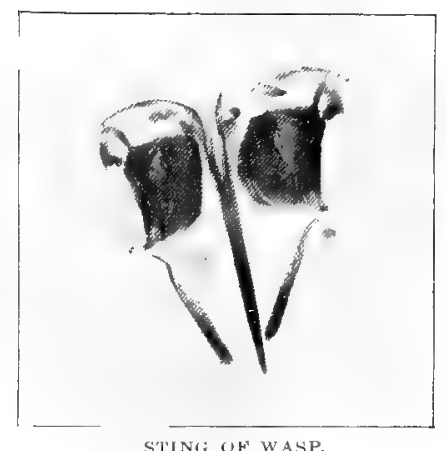

There are about twenty hooks on the front edge of the bind wing. These hook ovel a vein on the fore wing, and the two wings act together as one. 


\section{Additional Facts About Bees, Ants, and Wasps.}

Ants, bees, and wasps belong to the order Hymenoptera. The name means membrane wings, and is applied to those insects because the wings are mostly membrane, having very few veins. The metamorphosis is complete, the larva and pupa both being helpless, living in a cell and being attended by the mature insects until all their transformations are completed.

They must be classed with the insects having sucking mouth parts, although the mandibles are used for biting also. The social organization is very complex. Among the bumblebees and hive bees there are three kinds of individuals : the queens, or females; the drones, or males; and the workers, which are sometimes called neuters but really are undeveloped females. The queens lay the eggs. The presence of the drones is necessary, to fertilize the eggs ; and the workers, which constitute the most numerous class, attend to storing loney, making wax, and feeding the young bees.

Honey is obtained from flowers. Nectar, when it is gathered, contains more water, more essential oils, and less formic acid, than honey. When a cell is filled with honey, formic acid is added to the honey from glands in the head, and the cell is capped over with wax. Formic acid is the same poison that is ejected by the sting, and it acts as a preservative of the honey. Honey that is taken before the cells are capped over will usually ferment and spoil. Pollen is the pollen of the flower, and is gathered to feed the young bees. Wax, from which honeycomb is made, is secreted by the bees from glands which open on the abdomen. When making wax, some of the bees remain stationary in the hive and are fed honey by other bees. They eat about twenty-one pounds of honey for ivery pisund of wax they secrete. The workers take 
the wax away as fast as it is secreted and build it up into honeycomb. The sting serves as a means of defense. The barbs on the lancets account for the fact that the sting is so frequently found in the wound, and the fact that the poison is an acid indicates that ammonia or a solution of soda in water, applied quickly, is a remedy, because either of these will neutralize an acid.

The bumblebee gathers honey especially from red clover and from thistles. The tongue of the hive bee is too short for the tubes of these flowers. When a bumblebee visits many flowers of clover in succession, some of the pollen of one flower, by sticking to the hairy tongue, is brought into contact with the stigma of another flower. In this way bumblebees bring about cross fertilization of the flowers. This cross fertilization is necessary to the continuous production of red clover. Without it, very little seed will be produced. Frequently two crops of clover are produced in one year. The first crop is usually cut for hay. It has very little seed, as there are few bumblebees so early in the year. The second crop has an abundance of sced, as there are many bumblebees late in the season.

When clover was introduced into Australia, it produced no seed, and the fields had to be seeded every second year with imported seed. But bumblebees were introduced, and now the clover produces plenty of seed.

Other insects besides bees aid in the cross fertilization of plants. Wasps, butterflies, moths, and flies of certain families, fertilize different kinds of flowers.

The bumblebee is colored yellow and black, a very conspicuous combination, and it is frequently seen on clover blossoms, which furnish a contrast that is even more conspicuous. The bee, then, is not concealed by its color. The color of the bee is said to be a warning color. It is a danger signal to other animals. 
It is an advantage to the bumblebee to be thus colored, for other animals, aware of its stinging power, will let the bee alone if they know where it is.

The drone bumblebee has no sting. In some species, however, it is even more yellow and flaunts a more conspicuous danger signal than the stinging bumblebee. The conditions of mimicry are found in the drone bumblebees.

Wasps are of two kinds, the social and the solitary. The social wasps have the same three kinds of individuals that are found among the bees. They build nests like honeycomb, with six-sided cells, out of paper. The true social wasps build these combs in sheltered places, and put no covering over them. The hornet builds the same kind of paper nest, but surrounds the nest with a paper envelope. The paper is made from disintegrated woody fiber, obtained from weather-beaten boards or sticks of wood. The young are reared in these cells. The wasps themselves eat regetable food, but they feed the young upon the bodies of other insects.

The solitary wasps.either dig holes in the ground or build nests of mud which they place in some sheltered position. As soon as a cell is built, the wasp provisions it with the bodies of other animals, such as spiders, caterpillars, cicadas, etc. Each kind of wasp selects a particular kind of animal with which to provision its nest. The wasp, having found a spider, for example, stings it in a ganglion of the nervous system on the ventral side of the body. If a caterpillar is the object of attention, the sting is thrust into nine or ten of the ganglia. The slender pedicel of the wasp, by which the abdomen is attached to the thorax, enables it to reach around to the under side of the spider or the caterpillar and sting it in the proper place. The effect of this sting is to paralyze the victim, not to kill it. It is then carried to the nest 
and packed in the cell. Sometimes ten or fifteen spiders, all paralyzed, are packed into one cell. Even if they should die, as they must after awhile, the preservative effect of the formic acid is sufficient to keep the bodies from decay. The egg is then laid, and the nest sealed up. The wasp larva hatches, eats the food prepared in advance for it, and finally breaks out of its mud cell a mature wasp. The solitary wasps have only two kinds of individuals, male and female.

In some respects, the ants represent the highest degree of insect intelligence. Not only have they the same three classes in a colony that the bees and wasps have, but in some cases there is a fourth class, the soldiers, whose only business is to fight, defending the nest or attacking other colonies. It has long been known that certain kinds of ants make forays upon the nests of other kinds, whose larvæ they carry off and rear in their own nests to serve as slaves. It is also known that certain ants keep in their nests and care for certain plant lice which secrete a sweet liquid much appreciated by the ants. Such plant lice are called ants' cows. Other insects are found in ants' nests, and we are unable to account for their presence except by likening them to our own domestic animals.

The agricultural ant of Texas is known to clear off a piece of ground from 6 to 8 feet in diameter, keep down the weeds, allowing a kind of grass known as ant rice to grow, gather the grains of rice when they are ripe, store them away in granaries, and bring them out to dry when they get wet. It has not been seen to plant the rice, but some people believe that it does so.

The leaf-cutting ant of Central America is known to cut pieces of leaves and carry them into a nest, where they ferment and form a hotbed in which springs up a kind of fungus that furnishes the principal food of the ants. 
These are some of the facts that are relied upon by some to show that in amount of intelligence ants rank next to man.

\section{Orders of Insects.}

Copy into your notebook, spell, and pronounce, the following words :-
Or thorp'te ra
Lep i clóp'te ra
Co le öp'te ra
IIe mǐp'te ra
Neu róp'te ra
Díp'te ra
Hy me nöp'te ra

These seven orders are the orders of insects as established by Linnæus. Recent entomologists make the following divisions:-

Thys a nū'ra-spring tails

Eph e měr' i da-may flies

Od o na' ta-dragon flies

Ple cơp'te ra-stone flies

Cor ro děn'tia-book lice

I sơp'te ra-white ants

Mal lóph'a ga-bird lice

En plex óp'te ra--earwigs

Or thip'te ra--grasshoppers

Phy sóp'o da-thrips

He míp'te ra-giant water bngs

Neu rơp'te ra-corydalis, ant lions

Me cŏp'te ra-scorpion flies

Tri ę̧óp'te ra-caddice flies

Lep i dóp'te ra-butterflies, etc.

Díp'te ra-house flies, etc.

Siph o nŭp'te ra-fleas

Co lo óp'te ra-lieetles

IIy me nóp'te ral-bees, wilsps, ants 
Make a table of differences among the seven orders of insects, according to the following form :-

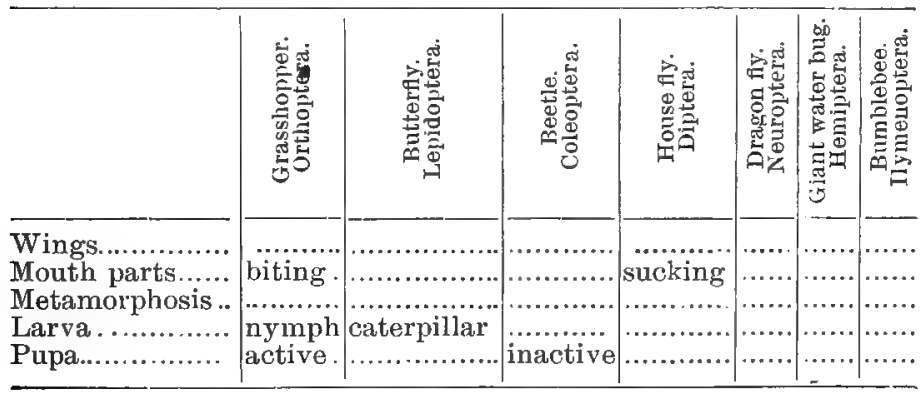

Make a table of resemblances among the seven orders of insects, after the following form :-

\begin{tabular}{l|l} 
Grasshopper & 2 compound eyes \\
1 pair of antennæ \\
2 pairs of jaws \\
House fiy \\
Butterfly \\
Beetle \\
Giant wairs of wings \\
jointer bug \\
Bumblebee \\
segmented appendages \\
3 body divisions \\
17 body segments \\
breathe by spiracles \\
reproduce by eggs \\
double nerre cord and ganglia \\
chitinous exoskeleton \\
white blood
\end{tabular}

Compare this table with the one on page 31. What characters found in that table are omitted in this one?

Orders which are alike constitute a class. These seven orders agree in the many characteristics expressed in the table of resemblances. They constitute a class. The name of this class is Insecta. An insect, then, is an animal having all the characteristics 
mentioned in the table of resemblances. This is not a good definition, but it will do until we can make a better one. When we say of a thing, "This is an insect," we mean that it possesses all the characteristics mentioned in this table of resemblances.

\section{Logical Definition.}

A Lepidopter is an insect having scaly wings, sucking mouth parts, complete metamorphosis, whose larva is called a caterpillar, and whose pupa is inactive. This is called a logical definition. Its predicate noun is the name of the class to which the order belongs, and the modifying characteristics are the differences which separate the order Lepidoptera from the other orders of the class Insecta. Now, from your table of differences, make a similar definition of each of the other orders of the same class.

\section{To the Teacher.}

The purpose of making these tables of resemblances and differences is to train the mind in its power of discrimination, comparison, generalization, and logical definition. The tables should be made by the pupils, "as far as possible withont reference to those in the book, which are inserted merely to show how to make such tables and how to use them.

\section{Review Topics on Insects.}

1. Name the seven orders of insects. Give examples of each.

2. What is meant by metamorphosis?

3. Name four stages in the metamorphosis of insects.

4. What is molting?

5. Show the necessity for molting.

6. Describe a compound eye.

7. What are ocelli?

8. What are antennæ? 


\section{The Dragon Fly.}

9. Where does a dragon fly live?

10. Where does it lay its eggs?

11. Describe the larva.

12. What mouth parts has a dragon fly?

13. What kind of wings has a dragon fly?

14. What is the pterostigma? The nodus?

15. How many segments in the abdomen?

16 What does a dragon fly eat?

\section{The Giant Water Bug.}

17. To what order does a giant water bug belong?

18. What kind of antennæ has it?

19. Describe the mouth parts. To what is each homologous?

20. Tell how the wings fasten.

21. Describe the wings

22. What peculiarity have the fore legs?

23. What peculiarity have the hind legs?

24. What is peculiar about the nerve cord?

\section{The House Fly.}

25. Describe the antennæ.

26. Describe the eyes.

27. Describe the mouth parts. Indicate the homologies.

28. Where are the lancets? Of what use are they?

29. Of what use are the palpi?

30. Describe the wings.

31. What are the balancers? The winglets?

32. Describe the foot.

33. Where are the eggs laid?

34 . What other insects belong to the same order as the house fly?

35. What is the larva called? 
The Beetra.

36. Describe the antenñ.

37. Describe the mouth parts.

38. Name all the parts of the leg.

39. Describe the wings.

40. What are the elytra?

41. How do the inner wings fold?

42. Where are the spiracles?

43. Describe the metamorphosis.

44. What is the larva called?

\section{The Butterfly.}

45. What mouth parts has the butterfly?

46. To what is the sucking tube homologous?

47. Describe the wings.

48. Describe the legs.

49. Describe the metamorphosis.

50. What is the larva called? The pupa?

51. What is a cocoon?

52. Tell what you know of the mouth parts of Cecropia.

53. State five differences between butterflies and moths.

\section{The Bumblebee.}

54. Describe the antennæ.

55. Describe the eyes.

56. Tell what you can of the mandibles.

57. Describe the other mouth parts.

58. Describe the wings.

59. Describe the legs.

60. Describe the sting.

61. What is the use of the sting?

62. What is pollen? Wax? Honey?

63. Tell of the social organization of bees.

64. Describe the metamorphosis.

65. Tell of the nests of paper wasps. 
66. Tell of the nest habits of mud wasps.

67. Discuss the intelligence of ants.

\section{General.}

68. Tell how an insect breathes.

69. What is meant by homologous parts?

70. What are vestigial organs?

71. What is protective coloration?

72. What is mimicry? Give examples.

73. How does the resemblance to Anosia protect Basilarchia?

74. Of what is the skeleton of an insect composed? How is it joined together?

75. Describe the nervous system.

76. What senses and sense organs have insects?

\section{Some General Considerations About Insects.}

There are about 250,000 species of insects already known and described, and these are perhaps not more than one-tenth of the species that exist. With the probable exception of some classes of Protozoa, the insects constitute the largest class of animals, both in individuals and in species. Some insects are useful to man. Shellac, cochineal, gall nuts, silk, beeswax, and honey, are produced by them. The greatest benefit, however, is derived from their assistance in fertilizing plants.

Insects do much injury to mankind. Besides the personal discomforts arising from such insects as flies, mosquitoes, etc., the injury that insects do to crops in the United States each year is very great. Mr. Riley once estimated it at $\$ 300,000,000$ per year.

The study of insects is called Fintomology. In studying insects, it is quite helpful to collect and preserve them. An insect net is useful for collecting many kinds of insects. The net should be about 
eighteen iuches deep, and may be made of India linen, cheese cloth, bobinet, Swiss, or mosquito bar. For a handle, fasten a stick like a broom landle to a hoop about ten inches in diameter made of stout wire. When an insect is captured, it is killed by dropping it into a cyanide bottle. A cyanide bottle may be made from any wide-mouthed bottle. In the bottom of the bottle is placed about half an ounce of potassium cyanide, which is a most deadly poison. This is covered with sawdust well shaken down, over which some plaster of Paris mixed with water is then poured until a smooth surface is obtained. The bottle should be left open until the plaster of Paris is dry. It should then be stopped up, when the fumes of the cyanide, rising through the porous plaster of Paris, will fill the bottle, killing any insect that may be dropped into it.

After an insect is killed, it should be pinned. The pins used for this purpose are insect pins, which are long, slender, very sharp-pointed, and have round heads. Beetles are pinned through the right elytron.

The wings of butterflies and moths should be spread out and held in position on a setting board until they becomedry. A setting board is a board with a groove in the middle to receive the body of the insect while the wings lie flat on the side. The wings should be drawn forward until the hind edges of the fore wings are in a straight line.

A good book for the study of insects is Comstock's Manual of Entomology. Much valuable information about insects may be found in the United States Agricultural Reports and in the reports of the various state entomologists. There is no one book that will enable one to determine the species of every insect he may find, nor even all the species of any one order. $A$ series of tables for the determination of the family to which an insect belongs may be found at the back of this book. 


\section{CHAPTER IV.}

\section{THE SPIDER.}

1. How many body divisions? What may they be called?

2. How many legs? To what are they attached? How many segments in each leg? Homologize the parts with the segments of the leg of the grasshopper. If you find an extra segment, it may be called patella.

3. Which pair of legs is the longest? Examine the foot. Draw.

4. Find the eyes. How many? Draw.

5. Find the mandibles, with their poison fangs. Draw.

6. Find the maxillæ. See the palpi. If the palpi are swollen, it indicates a male. Are there antennæ?

7. At the tip of the abdomen, on the under side, note the spinnerets. How many? Of what is each composed?

8. Near the base of the abdomen on the ventral side of the female, find a hollow, curved tube, the epigynum. Draw.

9. Near the epigynum, find on each side an opening into the breathing organs, which may be called air gills, or lung sacs.

\section{THE DADDY LONGLEGS.}

1. Identify the body divisions.

2. Where are the eyes? How many? What kind? 
3. Identify the mouth parts. Draw one of each pair.

4. How many legs? To what attached? Which is the longest pair? How many segments in each?

5. Examine the foot. How can such slender legs be adapted to this animal's habits of life?

6. How many segments in the abdomen? Do you find the means of breathing?

7. What kind of food does this animal eat? How does it get food? How can it escape from its enemies?

8. Of the animals that you have studied, which one most nearly resembles the daddy longlegs?

9. Make a table of differences between the spider and the daddy longlegs.

\section{Additional Faets Alout the Spider and the Daddy Longlegs.}

The spider and the daddy longlegs are taken to represent the class Arachnida. The spider belongs to one order, the Araneina, and the daddy longlegs to another order, the Phalangidea.

The daddy longlegs catches small insects which it finds on various kinds of clustered flowers, or in other places. Its favorite method of hunting is to run about over the tops of thickly clustered shrubs or weeds. Clumps of Symphoricarpus, or wolf-berry, are favorite localities. For this habit, the long legs and small body are admirably adapted.

Spiders are provided with a large fang on each mandible, which folds up when not in use. It is hollow and is connected with a gland in the head. It is called a poison fang, and the spider is generally supposed to be a very poisonous creature. The writer has caught hundreds of spiders with the naked hand, and has been bitten but twice, by two particularly 
ricious looking spiders. In neither case was there any indication of a poisonous effect. Such is the testimony also of almost every other experimenter with spiders.

Some spider's spin webs. The web is of silk, and comes out as a liquid from numerous tubes which constitute the spinnerets. It hardens upon exposure to the air. There seems little probability of making use of spider web in a commercial way, although the French government is making elaborate experiments in regard to it. Each spider would have to be kept in a cage by itself, for when several are put together, some of them will eat the others until only one is left. This would make spider silk very expensive.

The webs are sometimes of quite intricate patterns. When an insect flies into one of the webs, the watchful spider hurries out and wraps it about with silk, thus completely entangling it, and then proceeds to eat the soft parts of the captive.

Some small spiders are enabled to travel long distances upon the webs they weave, which are buoyed up and drifted about by the air.

The jumping spiders make no webs, but selze their prey by jumping upon it. They are very active. Among nearly all spiders, the female is the larger.

The eggs of spiders are laid in a mass which, in some species, is surrounded by a covering of silk and either carried around by the spider or fastened to a tree or other support. The metamorphosis is direct.

\section{'THE CENTIPEDE,}

(Scolopocryptops.)

1. Are there any body divisions? Identify the head distinctly.

2. Are there any eyes? What kind? 

each?

3. How many antennie? How many segments in

4. Find the mandibles. Are the things you take to be mandibles, true mandibles? Are they on the head? Are they jointed?

5. You may call this pair of mandible-like appendages the maxillipeds, or foot jaws.

6. Find and identify the true mouth parts. Draw one of each pair.

7. How many body segments behind the head? What does each segment bear? How do the legs on the first segment differ from those on the other segments? How do the legs on the last segment differ from the other legs?

8. Do you find spiracles? On what segments? How many?

9. Do you see any way to explain why an insect's jaws move sideways?

\section{THE THOUSAND LEGS.}

(Polydesmus.)

1. Are there any, body divisions? Identify the head clearly.

2. Find and draw one of each pair of mouth parts and antennæ.

3. Find the eyes. Are they simple or compound? How arranged? Compare with the eyes of a caterpillar.

4. How many segments in the body? How many pairs of legs? Hold this fact until we study the earthworm.

5. How many segments on each leg? Are all the legs alike? Draw one.

6. Do you find spiracles? How many?

7. In what respects does a caterpillar resemble a thousand legs? 
Make a table of differences between a butterfly and a caterpillar, and in a parallel column compare the thousand legs, in this manner:

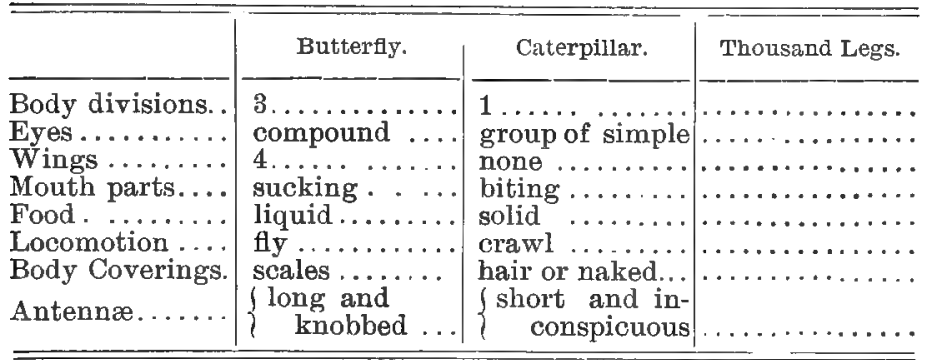

From the similarities manifested by the foregoing table, you will probably conclude that a caterpillar resembles a thousand legs more closely than it does a butterfly.

\section{Additional Facts About the Myriapods.}

The centipede and thousand legs are taken to represent the class Myriapoda. The centipedes belong to the order Chilopoda; and the thousand legs belong to the order Chilognatha.

Make a table of differences between the two.

The centipede from which the outline is made, Scolopocryptops sexspinosus, is a small animal and is found throughout the eastern and southern parts of the United States. It is found usually under stones and logs which lie on the ground. Its food is principally earthworms, which it pursues into their burrows. It is very active, and the strong maxillipeds enable it to obtain a very firm hold on the body of the earthworm. The hind pair of legs is directed backward, thus furnishing it an anchor which will prevent its being dragged along by the muscular efforts of the earthworm. Living entirely in dark places, it has no need for eyes, and the name Scolopocryptops indicates their absence. 
The centipede is a very active and a very vicious little creature. The usual way of catching one is to seize it quickly with the fingers as soon as the stone is turned over. In such a case, the centipede tries to bite, and frequently succeeds. No poisonous effects, however, have ever been experienced by the writer, who must have been bitten a hundred times. The large centipede of the southwestern states, Scolopendra, is two or three times as long as the Scolopocryptops, but resembles it closely in every structural respect.

The maxillipeds are remarkable organs. They are located on a segment behind the head. They are jointed. In both position and structure, they agree with the legs. They must be homologous to legs. But they work sideways, like jaws, and are used as jaws. The jaws (mandibles) have the same position they do. So we must conclude that maxillipeds are homologous to jaws. But by the axiomatic proposition that things which are homologous to the same thing are homologous to each other, the mandibles of a centipede must be homologous to the legs of a centipede. But the mandibles of a centipede are clearly homologous to the mandibles of a grasshopper. The refore it seems clear that the mandibles of a grasshopper are homologous to the legs of a grasshopper. We may illustrate the homologies by a diagram :-

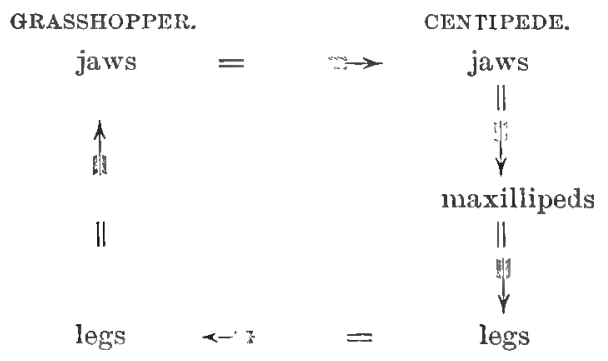

Therefore, ctc. 
This enables us to understand more clearly what is meant by homology, and to explain why we count one body segment in the head for each pair of paired appendages, and so determine that the body of the grasshopper is composed of seventeen body segments. This also enables us to explain why the mandibles of the grasshopper move sideways. The appendages are paired on each segment, and so are brought to oppose each other, just as the two hands of a man together seize upon an object to hold it or to lift it up.

\section{To the Teacher.}

The utility of the study of homology is to train the mind to perceive logical identity. The homology of the maxillipeds and the demonstration of the identity of the jaws of a grasshopper with the legs is an important lesson, and should be carefully prepared and worked out. 


\section{CHAPTER V.}

\section{THE CRAWHISH.}

1. How many body divisions? The front one is called the head thorax, or cephalothorax. Find a cross groove separating what might be called the head from the thorax. This is called the cervical groove.

2. Find the pointed projection in front. This is called the rostrum.

3. The entire covering of the cephalothorax is called the carapace.

4. How many segments in the abdomen? The middle piece of the tail fin is the telson. Is there any reason for calling it a segment?

5. To which segment are the side pieces of the tail fin attached?

6. Separate the third segment of the abdomen from the second and fourth. Remove the interior contents. Examine. The dorsal part of the ring is the tergite. (Compare with the name tergum of the grasshopper.) The ventral part of the ring is the sternite. The side pieces are the pleurites.

7. The appendages are the swimmerets. Observe that each swimmeret is composed of a main stalk and two branches.

8. The main stalk is the protopodite. The outer branch is the exopodite. The inner branch is the endopodite.

9. Do the side pieces of the tail fin have this structure? Are they swimmerets? 
10. If the swimmerets on the first and second segments of your specimen are large, it is a male; if they are small it is a female.

\section{The Cephalothorax.}

1. Lift up the free edge of the carapace. This part of the carapace is the gill cover, or branchiostegite. Inside are the gills.

2. How many pairs of legs?

3. Examine one of the hind pair of legs. Of how many segments is it composed? Draw.

4. Examine the third pair of legs. Draw.

5. Examine the first pair of legs. Draw.

6 . Find the third, second, and first pairs of maxillipeds. Draw one of each pair. Can you find a main stalk and two branches?

7. Find the second and first pairs of maxillæ. Draw one of each.

8. Find the mandibles. Find the mandibular palpus. How many segments has it? If you pull off the mandibles, you will probably find the large muscles which move them.

9. Find the gills. Draw one. How many gills? What appendages bear gills, and how many gills belong to each of these gill-bearing appendages?

10. In the front of the gill chamber, find the gill scoop, or scaphognathite. To what appendage is it attached? What is its use? What separates the gills from the gill scoop?

11. Find the antennæ. Can you discover a main stalk and two branches? The two branches are very unlike each other. Draw.

12. Find the antennules, or little antennæ. Can you find the main stalk and two branches? The two branches are very similar.

13. Find the ears, or otocysts, on the upper side of the basal joint of the antennules. 
14. Find the eyes. Are they simple or compound? See how they can move. Are they on stalks, or are they sessile?

15. How many pairs of paired appendages has a crawfish? If each pair of appendages indicates a segment, how many segments in the body of a crawfish? Is any segment of the body without a pair of appendages?

16. Put a piece of the shell into strong vinegar or other acid. If bubbles arise, it indicates that the shell is composed in part of lime.

\section{The Internal Structure.}

1. Carefully remove the carapace and pin the crawfish, back upward, under water.

2. Find the heart. Note its shape and position. Draw.

3. Find one artery leading backward, and three leading forward. To what organs do the forward arteries go?

4. Find holes, like slits, in the heart. How many?

5. Find the stomach. Trace the passage from the mouth to the stomach. Is it behind or in front of the heart? Is it in the head or in the thorax?

6. Slit open the stomach. Examine the inside. Find three teeth, which constitute the principal part of the grinding apparatus. Draw.

7. Trace the intestine to its outlet.

8. Distinguish other organs: liver, green gland, and reproductive organs.

9. See the muscles in the abdomen which bend and straighten it. Which muscle bends it, and which muscle straightens it? The bending muscle is the flexor, and the straightening muscle is the extensor. Which muscle is the larger?

10. Separate the two parts of the flexor muscle and find the nerve cord in the floor of the abdomen. 
Is it double? How many ganglia do you count? Draw a portion of the cord with its ganglia and nerves.

11. Trace the nerve cord through the thorax. Find where it passes around the cesophagus. Find a ganglion above and below.

\section{The Live Crawfish.}

1. How does a crawfish move when swimming? With what organ does he swim? How does he walk?

2. How does a crawfish breathe? Where does the water go into the gill chamber? Where does it come out? What makes the water flow over the gills? Put a small drop of ink in the water near the hinder edge of the carapace. Look for it to appear near the mouth.

3. Does a crawfish cast off its shell? Where does a crawfish live? Is there more than one kind of crawfish in our vicinity?

4. Why can a crawfish live out of water longer than a fish?

5. Where are the eggs borne? Do the young crawfishes look like the old ones?

\section{THE SOW BUG.}

1. Locate the head, thorax, and abdomen. How many segments in the thorax? In the abdomen?

2. On the head, find the eyes. Are they stalked or sessile? Simple or compound?

3. Find the antennæ. How many segments? How many pairs of antennæ?

4. How many pairs of jaws? Draw one of each pair. Are there palpi?

5. Find the legs. How many pairs? Do all the pairs extend in the same direction? How many segments in each leg? Draw.

6. Find the gills, under the abdomen. How many?

7. Test the shell with acid. Is there any lime in it? 


\section{THE CYCIOPS.}

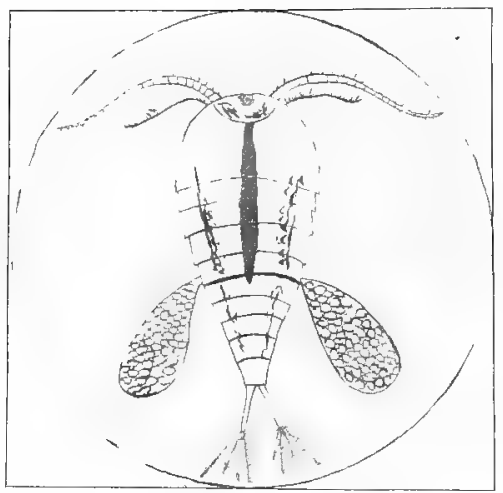

CYCLOPS.

1. See the carapace. How many segments has the thorax?

2. See the eye. Is it compound? Is it movahle?

3. How many joints in the antennæ?

4. How many segments in the abdomen? How does it end? How many spines at the tip?

5. If your specimen is a female, note the external ovisacs. Trace the intestine.

\section{THE DAPHNIA.}

1. See the shell. Is it plain or reticulate?

2. See the eye. Is it simple or compound? Movalile or not? Notice the eye muscles.

3. Trace the intestine. See the broad cavity above the intestine. If your specimen is a female, you will probably find eggs in it.

4. Find the leart.

5. Is there a spine at the posterior end of the abdomen?

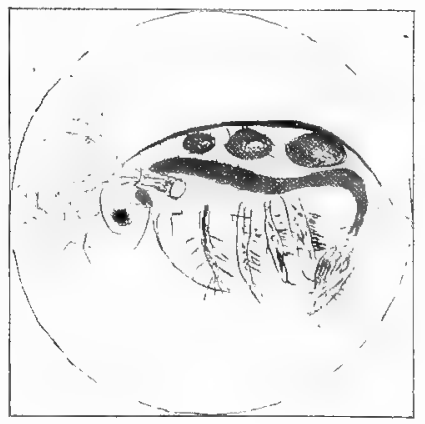

DAPENIA.

6. Draw the antenne carefully.

Nore.-Daphnia and cyclops are too small to be satisfactorily studied without a compound microscope. The stuclent, however, ought to become familiar with the genem appearance of each as seen by the unaided eye and with the simple lens. 


\section{Additional Facts about the Crustaceans.}

The crawfish introduces us to a different mode of breathing; that is, by means of gills. Breathing, or respiration, consists essentially of an exchange of gases. The tissues of the body need to be furnished with oxygen. This oxygen must come indirectly from the air. When oxygen reaches the tissues of the body, some of it is used in doing work or in generating heat. The result in either case is the production of carbon dioxide, which must be removed from the body. In the crawfish, the blood carries the carbon dioxide from the tissues, where it is generated, to the gills. The water which flows over the gills contains oxygen, which it has absorbed from the air. The blood carrying carbon dioxide flows into the gill filaments, where it is separated from the oxygen contained in the water by only a thin, moist membrane, which is the outer layer of the gill filament. Under these conditions, the carbon-dioxide carried by the blood leaves the blood and passes through the gill membrane into the water, and the oxygen in the water leaves the water and passes through the gill membrane into the blood.

In order that this exchange of gases may take place, the gill membrane must be kept moist. A crawfish can live out of water as long as its gills are moist. This will enable us to see the advantage of the gill covering. It prevents the rapid drying out of the gill and enables the crawfish to live some time out of water. If necessary, the crawfish can travel overland from pond to pond.

There must be oxygen in the water. Water that has been boiled has liad all the absorbed oxygen driven off. So crawfishes cannot live in boiled water unless it has absorbed oxygen since the boiling. Water that has given up its oxygen to the gills must 
be removed, and fresh water must take its place. There is a necessity for the production of a current of water over the gills. This is brought about by the action of the gill scoop, situated in front of the gills. The gill scoop, when working rapidly, moves about three times in a second, and produces a current from backward to forward.

Since this is the direction of the current of water over the gills, it is an advantage in breathing for the crawfish to swim backward. The movement backward assists the current flowing over the gills. So, also, when crawfishes lie in a running stream, they will usually lie with their heads down stream.

The blood in crawfishes is white, and it exists in considerable quantity. When a leg of a live crawfish is cut off, the blood flows freely from the wound. It contains an abundance of white corpuscles, but no red ones such as we shall find in vertebrates.

Some kinds of crawfishes dig holes from the surface of the land downward several feet, usually piling the excavated dirt around the mouth of the burrow, forming a chimney. These holes generally reach downward to the water, and are most numerous in low places, from the surface of which the water has almost or quite disappeared.

Crawfishes molt as insects do. They molt about five or six times the first year of their lives, and usually molt once each year thereafter. A crawfish may live to be twelve years old.

All crawfishes living in the eastern and central part of the United States belong to the genus Cambarus, and have seventeen gills on each side of their body. English crawfishes, and those of California, have eighteen gills on each side and belong to the genus Astacus.

The crawfish is the fresh-water lobster. In general appearance, and in everything except size, the craw fish 
and lobster are very nearly alike. A crab differs from a crawfish in the fact that the abdomen is very much reduced in size and is folded under the cephalothorax.

The sow bug belongs to an order called Tetradecapoda, or fourteen-footed crustaceans. The gills are leaf-like plates situated under the abdomen. The animal lives in damp places, although most members of the order are truly water animals.

Daphnia, Cyclops, and Cypris belong to the order Entromostraca. They are all very small crustaceans, are found abundantly in our lakes and ponds, and furnish a part of the food for young fishes. The order is now divided into three groups, called Copepoda, Cladocera, and Ostracoda, represented by Cyclops, Daphnia, and Cypris, respectively.

\section{Review Questions.}

The Crawfish.

1. What are the body divisions of the crawfish?

2. What is the cervical groove?

3 . Where is the rostrum?

4. Where is the telson?

5. How many segments in the abdomen?

6 . What is the carapace?

7. Name all the appendages of the crawfish?

8. Are the eyes stalked or sessile?

9. What appendages bear gills?

10. How many gills does each of the gill-bearing appendages have?

11. What is the gill scoop? What is its use?

12. To what is the gill scoop attached?

13. Describe the function of the gills.

14. How is a current of water produced over the gills? What makes it flow? Describe its course.

15. What is the typical form of an appendage? Name the three principal parts. 
16. Describe the two pairs of antennæ.

17. Where are the ears?

18. How distinguish the male from the female?

19. How many body segments? What indicates the number?

20. Which body segment bears no appendage?

21. What pairs of legs are furnished with pincers?

22. Where is the stomach?

23. Describe the nerve cord. How many ganglia?

24. Where is the heart? How does the blood get into the heart?

25. What kind of blood has the crawfish?

26. What muscles enable the crawfish to swim?

27. Why does the crawfish swim backwards?

28. How is a crawfish enabled to stay so long out of water?

29. Where are the eggs carried?

30. Of what is the shell composed?

31. What is meant by the molting of a crawfish?

\section{The SpIDer.}

32. How many body divisions has the spider?

33. How is the web produced?

34. What is silk? Where are the spinnerets?

35. How many legs has the spider?

36. What are the breathing organs?

37. How many eyes has the spider? Are they simple or compound?

\section{The Centipede.}

38. How many body segments has the centipede?

39. Where are the maxillipeds borne?

40. Where does the centipede live? What is its food?

41. Is there any difference between the thorax and the abdomen?

42. How does a centipede differ from a caterpillar? 
Make a table of differences between the grasshopper, spider, centipede, and crawfish, after the following plan :-

\begin{tabular}{|c|c|c|c|c|}
\hline & $\begin{array}{c}\text { Grasshopper. } \\
\text { Insecta. }\end{array}$ & $\begin{array}{l}\text { Spider. } \\
\text { Arachnida. }\end{array}$ & $\begin{array}{l}\text { Centipede. } \\
\text { Myriapoda. }\end{array}$ & $\begin{array}{l}\text { Crawfish. } \\
\text { Crustacea. }\end{array}$ \\
\hline sody divisions & 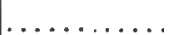 & 1 & . & . \\
\hline Exoskeleton ..... & $\ldots \ldots$ & $\cdots$ & $\cdots$ & •.... \\
\hline Antennæ...... & $\ldots \ldots$ & $\cdots \cdots$ & $\ldots \ldots \ldots$ & $\ldots \ldots \ldots \ldots$ \\
\hline Eyes.......... & $\ldots \ldots$ & $\ldots \ldots \ldots$ & $\ldots \ldots \ldots$ & $\ldots \ldots$ \\
\hline Body segments. & $\ldots \ldots$ & $\ldots \ldots$ & $\ldots \ldots$ & $\cdots$ \\
\hline Breathing..... & $\ldots \ldots \ldots$ & . & $\ldots \ldots \ldots$ & $\ldots \ldots \ldots$ \\
\hline Number of legs. & $\ldots \ldots$ & $\ldots \ldots \ldots \ldots$ & $\ldots \ldots \ldots$ & $\ldots \ldots \ldots$ \\
\hline Wings. . . . . . . & $\ldots \ldots$. & $\ldots \ldots \ldots$ & $\ldots \ldots \ldots \ldots$ & $\ldots \ldots \ldots$ \\
\hline Locomotion .... & $\ldots \ldots \ldots$ & $\ldots \ldots$ & $\ldots \ldots \ldots$ & $\ldots \ldots \ldots \ldots$ \\
\hline Habitat ....... & $\ldots \ldots \ldots$ & $\ldots \ldots \ldots$ & $\ldots \ldots \ldots$ & $\ldots \ldots \ldots$ \\
\hline
\end{tabular}

Make a table of resemblances among the grasshopper, spider, centipede, and crawfish, according to the following plan :-

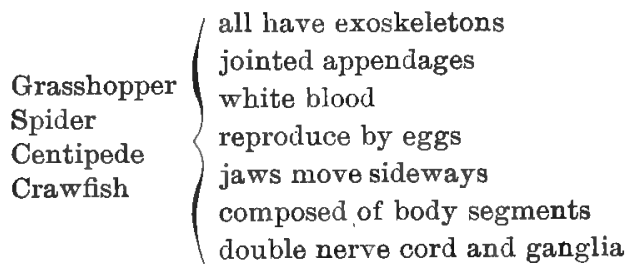

Compare this table with the table on page 55. Have any new resemblances been discovered? Have any resemblances on page 55 been omitted? Look for omitted resemblances in your table of differences.

The grasshopper, spider, centipede, and crawfish represent four classes of animals that resemble each other in the particulars indicated in the table. They are grouped together, and the group is called a Branch. The name of the branch to which these animals belong is Arthropoda. It is named from the jointed appendages. 


\section{Logical Definition.}

An insect is an arthropod which is composed of sevcnteen body segments grouped into three body divisions; has a chitinous exoskeleton, one pair of antennix, and turs sessile compound eyes; breathes by spiracles which open into trachex; has three pairs of legs and two pairs of wings; can move by flying; and lives in the air.

From your table of differences, make a logical definition of an arachnid, a myriapod, and a crustacean. 


\section{CHAPTER VI.}

\section{THE FISH.}

Almost any kind of fish will do for this study. These directions are written for the perch or the sunfish.

1. Measure the length, from the tip of the snout to the base of the tail. Measure the depth, the greatest distance between dorsal and ventral sides; width, the greatest thickness from right to left; length of the head, from the tip of the snout to the tip of the bony part of the flap on the side of the body. How many times is the depth, the width, and the length of the head, contained in the length of the fish?

2. Find the caudal fin, at the tail ; the dorsal, on the back; anal fin, the single fin below. These are the unpaired or median fins.

3. The pectoral fins are the front pair of paired fins. The ventral fins are the hind pair of paired fins.

4. Study each fin. Find two kinds of fin rays, and a membrane covering the rays. Is the membrane double or single?

5. The stiff, pointed rays are the spinous rays. The others are the soft rays or jointed rays. How many rays of each kind has each fin? D. III., 10, means that the dorsal fin. (D) has three (III.) spinous rays, and ten (10) soft rays. So indicate the number and kind of rays in each fin.

6. Study the rays. Do they branch? Draw carefully one of the soft rays. Sketch each fin. 


\section{The Eyes.}

1. Are the eyes movable? Are there eyelids? In what direction can this fish see? What parts of the eye can you see?

2. Find the anteorbital bone in front of the eye, and the suborbital below it.

3. Insert your finger into the mouth and find out whether there is a bone between the mouth and the eyeball.

\section{The Nostrils.}

How many nostrils (nares) are there, and how are they situated? Do they open into the mouth? Of what use are they?

\section{The Mouth.}

1. See how the jaws open. Note the shape of the mouth, when it is open and when it is closed.

2. The bones in the upper lip are the premaxillaries. How many?

3. Observe the backward extension of the premaxillary on top of the snout.

4. Do the premaxillaries bear teeth?

5. Observe the bones just back of the premaxillaries. These are the maxillaries. Do they have teeth? What is their shape?

6. Find a small patch of teeth in the roof of the mouth. These are borne on a bone called the vomer.

7. Find two bones (palatine bones) along the sides and a little way back of the vomer. Do they have teeth?

8. The front bone of the lower jaw is the dentary. Does it have teeth?

9. Examine the tongue. Can it be thrust out of the mouth? Does it bear teeth?

10. Can you find teeth anywhere else in the mouth? 


\section{The Gill Covers.}

1. The gill covers are composed of four bones, the opercular bones.

2. The upper back one is the opercle. The upper front one is the preopercle. The lower back one is the subopercle. The other bone is the interopercle.

3 . Look below the opercular bones for the branchiostegal membrane, which is supported by the branchiostegal rays. How many rays are there? Draw the external appearance of the gill covers

4. See the narrow part of the body between the branchiostegal rays. This is the isthmus.

\section{The Gills.}

1. Raise one gill cover and find the gills. Find the bone which supports a gill. This is the gill arch. The small threads attached to it are the gill filaments.

2. The spaces between the gill arches are the gill clefts. How many gill arches? How many gill clefts? How many rows of gill filaments on each gill arch?

3. Find the gill rakers on the front side of the gill arches. Are all the arches supplied with them? On which gill are they the longest?

4. Find a red line, the gill artery, along the base of the gill filament.

5 . Find a red spot, like a gill, on the inside surface of the operculum. It is a false gill, or pseudobranchia.

\section{The Scales.}

1. How are the scales arranged? Is there a covering (epidermis) over the scales? Pull a scale out of a yellow or black spot. In what is the color?

2. Examine one of the scales after it has been pulled out. Notice radiating striæ running from the edge. 
3. Notice concentric striæ running around the edge.

4. Which is the anterior and which the posterior edge of the scale?

5 . Note fine teeth on the posterior edge of the scale. Draw.

6. Find a distinct line running along the sides of the body lengthwise. This is the lateral line.

7. Pull one scale out of the lateral line. Examine carefully. How does it differ from other scales?

8. How many scales in the lateral line?

\section{The Body Cavities.}

1. Find the opening of the intestine, in front of the anal fin. Cut through the body wall carefully from the anal opening to the isthmus. Cut away as much of the body wall on the left side as you can without injuring the internal organs.

2. Notice the silvery lining of the body cavity. This is the peritoneum.

3. Find a membranous partition near the front of the body cavity. This is the false diaphragm. The part of the body cavity in the front of it is the pericardial cavity. The part behind it is the abdominal cavity.

4. In the dorsal part of the abdominal cavity, find a thin membrane. 'This is the air bladder. Does the peritoneum cover it? Does it have any connection with the mouth or stomach?

\section{The Digestive Organs.}

1. Identify as well as you can the resophagus, stomach, intestine, liver, spleen.

2. What is the shape of the stomach? Where does 
the œsophagus enter it? Where does the intestine leave it?

3. Find the pyloric cæca, at the place where the intestine leaves the stomach. How many? Scrape away the fat and examine one carefully.

4. Trace the intestine. How many turns does it make? Notice the thin membrane (mesentery) which holds the loops of the intestine together. Where is it attached? Do you find any tubes running in it?

5. How many lobes has the liver? Where is it attached?

6. Find the bile sac, on one of the lobes. Is there a connection between the bile sac and the intestine? Draw. What is the use of the bile sac?

7. Identify the spleen. This is a small, red body back along the intestine.

\section{The Reproductive and Excretory Organs.}

1. Identify the reproductive organs, male or female. If a female, the ovaries will show the eggs.

2 . Is there a tube leading from the reproductive organs? Where does it open?

3. Find the kidneys. They are dark, slender bodies along the roof of the abdominal cavity.

4. Trace the kidneys backward to the urinary bladder. Where is the outlet?

\section{The Circulation.}

1. Identify the heart. The larger, angular portion is the ventricle. The softer, irregular portion is the auricle.

2. Find the venous sinus, a dark, thin-walled sac extending back from the auricle and in front of the false diaphragm. Can you find its opening into the auricle?

3. Find the hepatic vein, passing from the liver 
through the false diaphragm into the venous sinus. Are there other veins entering?

4. Find the arterial bulb in front of the ventricle. Trace the branchial aorta from the arterial bulb until it branches into the branchial arteries, one to each gill arch.

5. Trace one branchial artery along the gill arch until it enters the dorsal aorta.

6. Trace the dorsal aorta along the back as far as you can.

7. Is the heart single or double? Is it respiratory or systemic? Describe the course of the blood from the ventricle until it gets back to the ventricle again.

\section{The Nervous System.}

1. Cut off the head, scrape away the flesh, and slice off the top of the skull to see the brain.

2. Notice the cellular tissue above the brain.

3. The largest pair of lobes you see in the brain are the optic lobes.

4. In front of the optic lobes, find the pair of cerebral hemispheres, or cerebrum.

5. In front of the cerebrum, find two much smaller lobes, the olfactory lobes. Trace the olfactory nerves from the olfactory lobes forward.

6. Behind the optic lobes, notice the undivided cerebellum.

7. Behind the cerebellum, find the medulla oblongata, which is continuous with the spinal cord.

8. Find the optic nerves, below the cerebral and olfactory lobes. Trace them to the eyes. Do they unite? From which lobe does the nerve come that goes to the right eye?

9. Can you find small nerves (spinal nerves) branching from the spinal cord? How far back does the spinal cord extend? 


\section{The Skeleton.}

1. Clean the flesh from one of the bones of the spinal column.

2. Note the central portion (centrum). What shape is it on the ends?

3. Note the spinous processes. The one on the back is the neural spine. See the opening through which the spinal cord passed.

4. How many pairs of ribs has your fish? How are the ribs attached to the backbone?

5. To what are the fin rays attached?

\section{The Live Minnow.}

1. How does the fish swim? What is the chief organ of locomotion?

2. What is the chief use of each one of the fins?

3. Notice the action of the mouth and gill covers. Do both mouth and gill covers move at the same time? Why does the fish move his jaws so constantly?

4. Why does the fish generally lie with head up stream? Why does a fish die when it is taken out of the water?

5. Will these minnows ever grow larger? How many kinds of fishes do you know? How many kinds are on sale in the markets?

6. Do fishes ever rain down?

\section{Additional Facts About the Fish.}

The fishes represent the class Pisces. There are four groups of this class. Each group may be called an order, although each has been subdivided into several orders since the first division was made. The bony fishes belong to the order Teleostei. The sharks belong to the order Selachii, the sturgeon and garpike belong to 
the order Ganoidei, and the Australian, African, and South American lung fishes belong to the order Dipnoi. The Selachians have a skeleton that is cartilaginous throughout, while the skeleton of the Ganoids and of the Dipnoi is partly cartilaginous and partly bony.

The tail is the principal organ of locomotion. The other fins serve mainly to balance the fish, keeping it upright and guiding it in its course through the water. The pectoral and ventral fins are homologous to the fore and hind limbs of a dog or other mammal. Usually the pectoral fins are in front of the ventral fins, but this is not always so. When the ventrals are anterior to the pectorals, their ventral nature can be recognized by their being closer together and nearer the median line of the fish than the pectorals.

The vertebræ are concave at both ends. The spaces between the ends are filled with a cartilaginous substance which represents the notochord. The notochord is a cartilaginous rod which is found in the early life of every vertebrate, occupying the place of the backbone. In the sturgeon, and in other fishes with cartilaginous skeletons, the notochord persists throughout life; but in the bony fishes generally, as well as in all other vertebrates, bony vertebræ take the place of the notochord.

Usually, the tail fin is two-lobed and the lobes are of equal size. The spinal column ends at the place in which the tail fin begins. Such a tail is called homocercal. But in the sharks, and in some other fishes, the backbone seems to run out into one of the lobes of the tail, making that lobe much larger than the other. Such a tail is called heterocercal.

The fish breathes by gills, as the crawfish does. The water, however, goes over the gills from the front, instead of from behind. It enters the mouth when the mouth is open, and the closing of the mouth forces 
it out over the gills and under the gill covers. If a fish were to have its mouth propped open, it could not produce this current, and so would very likely suffocate. Since the current of water is backward over the gills, it is easier for the fish to breathe when it is fronting up stream. If it were held with the head down stream in a swiftly flowing current, it would have great difficulty in breathing. So, in running water, fishes generally lie with their heads up stream, and they swim up stream in preference to swimming down. In this way fishes are distributed to small streams, and at the time of a heavy rain, when furrows and ditches are filled with water, they may reach ponds that on ordinary occasions have no outlet, or may even be stranded on places that are dry when the rain is over. This is a sufficient explanation for most of the stories that we hear of fishes raining down.

The blood is red. It consists of many red corpuscles and a smaller number of white corpuscles floating in a liquid called the plasma. Each red corpuscle has a small body in the center called the nucleus. The blood of a fish has the same temperature as the water in which it lives. As the water in which a fish lives is generally colder than our bodies, and so feels cold to our hands when we put them into it, we say that the fish is cold blooded.

The heart consists of one auricle and one ventricle. Such a heart is said to be single. The blood is sent forward to the gills. In consequence of the fact that all the blood is sent from the heart to the breathing organs, the heart is said to be a respiratory heart.

When a fish is taken out of the water, it can live only so long as the gills are kept moist. When the gills dry out, as they do very soon, the membrane of the gills cannot exchange the respiratory gases, and the fish dies of suffocation. The gills of a fish are not 
so well protected against drying out as are the gills of a crawfish, so a fish cannot usually live so long out of water as a crawfish can.

From the gills the blood is gathered into the dorsal aorta, through which it is distributed to the body generally. It returns from the body through veins to the auricle. Since no part of the blood, after leaving the heart, can return to the place from which it started without passing both through the breathing organs and through some part of the system, the circulation is said to be complete.

The air bladder is homologous to a lung, although in our common fishes it is not a breathing organ. It is filled with gases secreted from the blood, and serves to make the body of the fish have the same specific gravity as the water in which it lives. If the muscles along the sides of the body contract, the air bladder is compressed, thus occupying less space, which action increases the specific gravity of the fish, enabling it to sink more readily. In the perch, the air bladder is attached to the walls of the body cavity. In the suckers, and in many other fishes, it lies free in the body cavity and is divided into two portions by a constriction around the middle. In the garpike, and in the ganoids generally, the air bladder contains many blood vessels and communicates with the osophagus by a short tube through which air can enter it. In these fishes, it serves as a partial lung and is of use in breathing. In the Dipnoi, or lung fishes, it is so efficient that, when necessary, the use of gills can be dispensed with, and the fishes are thus enabled to withstand for some time a complete drying up of the ponds in which they live.

In the perch, and in most bony fishes, the air bladder represents an organ that is in a state of retrogression. Instead of becoming more lung-like, it is becoming less so. 
The scales on the fish represent the exoskeleton. The bony skeleton inside, to which we refer when we speak of the skeleton, is the endoskeleton. The scales are entirely distinct from this. The scales along the lateral line are perforated, allowing communication with a series of lateral line sense organs, whose nature is not satisfactorily known. Perhaps their function is somewhat similar to that of the ear.

In the skin are located many muciparous glands which furnish a secretion that lubricates the fish in its passage through the water. This is what makes a freshly caught fish feel so slippery.

In the catfish, and in many other kinds, the skin is naked and the exoskeleton is undeveloped. In the sturgeon, the exoskeleton is developed as a series of bony plates.

\section{Review Topics on the Fish.}

1. Name all the fins of a fish.

2. Describe the structure of a fin.

3. What are the two kinds of fin rays?

4. How are the scales arranged?

5. What is the lateral line?

6. How many scales in the lateral line?

7. What is the principal organ of locomotion?

8. Name the opercular bones.

9. Describe the structure of a gill.

10. State the direction of the water as it goes over the gills.

11. What makes the water flow over the gills?

12. What does the fish breathe?

13. Why does a fish lie with its head up stream?

14. Describe the course of the blood through the body, naming all parts of the heart.

15. Is the circulation double or single?

16. Is the circulation complete or incomplete?

17. What is the false diaphragm? 
18. What are the pyloric cæca?

19. What kind of blood has the ish?

20. Why is a fish said to be cold blooded?

21. Sketch the brain, naming all the parts in their order.

22. Sketch a vertebra, naming all the parts.

\section{Vocabulary of a Fish.}

Words to be pronounced, spelled, and defined with reference to the specimen studied.

\begin{tabular}{|c|c|c|}
\hline 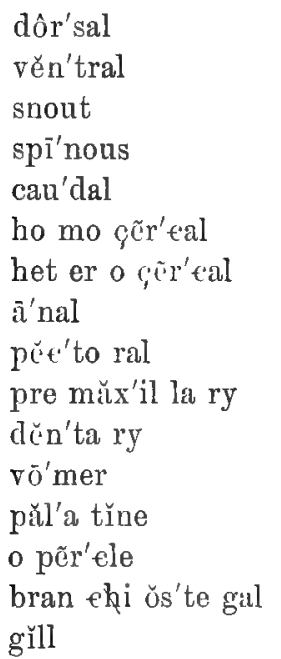 & 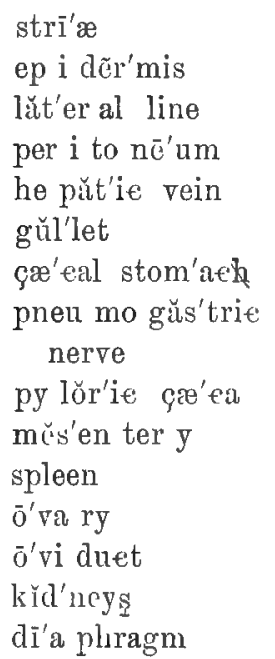 & $\begin{array}{l}\text { S sī'ulus } \\
\text { i al bulb } \\
\text { n ġe'al teeth } \\
\text { bræ } \\
\text { um } \\
\text { spine } \\
\text { l'la ob lon gĩ'ta } \\
\text { ěl'lum } \\
\text { lobes } \\
\text { rum } \\
\text { to ry lobeș } \\
\text { r'dial eăv'ity } \\
\text { ent }\end{array}$ \\
\hline
\end{tabular}




\section{CHAPTER VII.}

\section{THE FROG.}

1. Find the eyes, nostrils, mouth. Has the frog a neck? How many eyelids?

2. Find the ears. Notice the white spot in the center.

3. Has the frog teeth? If so, where? Examine the tongue. Where attached? Is it forked or not? Of what use is the tongue?

4. Study the legs. How do the fore and hind legs differ? How many toes on each?

5. The parts of the fore leg are arm, forearm, and hand.

6. The parts of the hind leg are thigh, leg, and foot.

7. Notice the color and texture of the skin.

\section{Internal structure.}

1. Remove the skin from the ventral side and cut through the body wall. Is there any diaphragm?

2. Identify the liver, stomach, intestine, heart, and lungs.

3. Beginning at the stomach, trace the intestine its entire length.

4. Notice the mesentery, which holds the intestine in place. In the mesentery, near the stomach, find the pancreas.

5. How many lobes has the liver? Find the bile sac.

6. In the mesentery, posteriorly, find the spleen. 
7. If your specimen is a female, find the ovary with its much contorted oviduct leading to the cloaca.

8. In many specimens you will find slender masses of fat. These are the fat bodies.

9. Find the kidneys, which are elongated dark bodies near the hind part of the backbone. From the kidneys, trace tubes, the ureters, backward to the urinary bladder.

10. Notice the lungs. Trace the trachea from the larynx to the lungs, observing the bronchial tubes.

11. Notice the great size of the lung cells, and the small number of them which constitute a lung.

12. Find the heart. Find where the aorta divides into two branches, the right and the left aorta. Find the three principal branches into which each aorta divides : the carotid, leading to the head ; the pulmocutaneous, leading one part to the lungs and the other to the skin; and the aorta proper, which leads to the rest of the body generally.

13. Trace the right and left aorta until they come together, forming the dorsal aorta. Continue until you find the iliac arteries, which lead to the hind legs.

14. Find the veins which bring the blood back to the heart.

15. How many cavities are there in the heart?

16. Make a diagram of the frog's circulation.

\section{The Nervous System.}

1. Find all the nerves you can that run from the spinal cord to the body cavity.

2. Notice the brachial plexus, sending nerves to the fore legs.

3. Notice the plexus of nerves going to the hind legs. Trace the principal nerve (sciatic) as far as you can.

4. Cut away the top of the skull, exposing the brain. Identify the following parts: optic lobes, 
which form the widest part of the brain; cerebrum, consisting of two elongated lobes in front of the optic lobes; olfactory lobes, very small, in front of the cerebrum; olfactory nerves, running under the olfactory lobes to the nostrils; cerebellum, very small, lying behind the optic lobes; medulla oblongata, continuing into the spinal cord.

5. Trace the optic nerves to the eyes.

\section{The Slkeleton.}

1. Has the frog ribs? How many vertebræ has it?

2. Notice the three long bones at the back of the spinal column. The middle one is called the urostyle. The bone on each side of it is called the ilium. What makes the frog look humpbacked?

3. Identify the bones of the fore leg and the shoulder girdle. The bone in front, on the ventral side, is the sternum. Of how many pieces is it composed?

4. The dorsal part of the girdle is composed of the scapulæ. The cartilaginous portion is called the supra-scapula. Note the two coracoid bones, and the two clavicles in front of them, all extending from the sternum to the scapula.

5. The first bone in the arm is the humerus. The next is the bone of the fore-arm, the radius. The bones of the hand are the carpals, metacarpals, and phalanges.

6 . Study the bones of the hind leg. Identify the femur, the tibia, the tarsal bones, the metatarsals, and phalanges.

7. Examine the skull. Is the lower jaw attached directly to the skull?

8. Observe the movement of the skull in nodding. A rounded prominence on the skull, fitting into a concavity of the first vertebra, is called a condyle. Do you find one or two condyles? 


\section{Additional Facts About the Frog.}

The frog breathes by lungs, but the lung capacity is small in consequence of the small number and large size of the air cells. Blood is plentifully supplied to the skin by a branch of the pulmo-cutaneous artery. The skin is naked, and when moist, an exchange of carbon dioxide for oxygen can take place through it quite readily. This supplements the lung breathing. This accounts in part for the fact that frogs are usually found near a pond or stream of water. When the ground or grass is wet, however, frogs often go long distances from a pond. A frog confined in a dry place, without water, will soon die.

Small frogs and toads are sometimes seen hopping over the ground in great numbers, usually after a rain, and this has led to a belief that frogs and toads rain down. The true explanation is that a great number of tadpoles have been developed in a near-by pond or some other body of water, and are just ready to move out from the pond. They seize upon the time of a rain, when the ground and grass and atmosphere are very moist, to leave the place of their development for some place where food can be more easily secured.

The heart has three chambers: two auricles and one ventricle. Only impure, or carbonated blood, is poured into the right auricle, and oxygenated blood, which comes from the lungs, into the left auricle. The two kinds mix in the ventricle, but by a curious arrangement of valves in the beginning of the aorta, the greater portion of the blood that goes to the lungs is that which comes from the right auricle, and the greater part that goes to the system is that which comes from the left auricle. This kind of circulation, in which pure and impure blood mix in the heart, is called a double, incomplete circulation. 
The two branches into which the aorta separates come together behind the heart, forming one dorsal aorta.

The corpuscles of the blood are large and elliptical in outline, and each is provided with a nucleus. With a compound microscope the movement of blood corpuscles can be seen in the capillaries of the web of a frog's foot. It can also be observed in the tail of a tadpole, in the tail fin of a minnow, and in the mesentery of a living frog or toad. Even with a simple lens some morement may be observed.

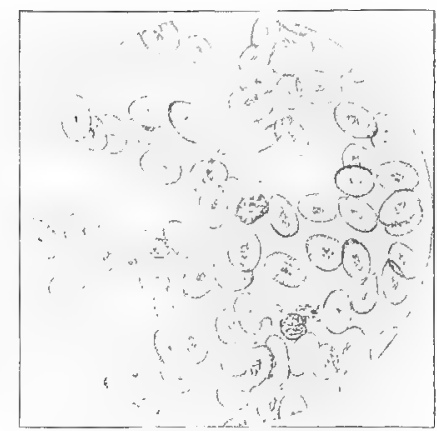

BLOOD CORPUSCLEG UF' FROG.

The intestine opens into a short, wide sac called the cloaca, which receives also the oviducts and the tubes from the kidneys. The long bones of the legs terminate in cartilaginous caps which are easily separated from the rest of the bones.

The frog is without any ribs or diaphragm. In man, these are the organs by means of which the air is taken into the lungs. The frog must breathe in another way. Under the throat or jaw is a large, flat muscle called the mylohyoid inuscle. When this muscle is depressed, the cavity of the mouth is enlarged, and air rushes in through the nostrils. The nostrils are then closed, either by valves in the openings, or by the tip of the tongue, or hy both, and the mylohyoid muscle is raised. The air is thereby forced down into the lungs. The process is repeated, air coming from the lungs and mingling in the mouth with fresh air from the outside. If a frog's mouth were propped open, could he breathe? 


\section{THE TOAD.}

Study a toad in the same way that you did a frog. Make a table of differences, as follows:-

\begin{tabular}{|c|c|c|}
\hline & Frog. & Toad. \\
\hline 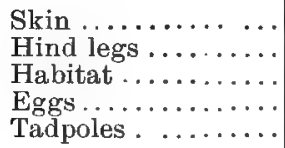 & 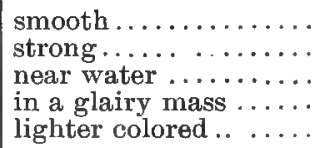 & 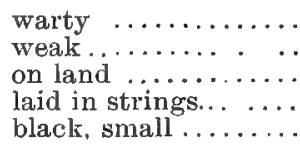 \\
\hline
\end{tabular}

\section{Additional Facts About the Toad.}

The toad is very similar to the frog in general appearance, but its body is thicker, its legs shorter and weaker. Its skin is warty and it is not confined to proximity to water. The skin is furnished with glands, from which a disagreeable liquid may be ejected when the toad is excited by danger or fear of danger. While the liquid is not poisonous, it is suffciently disagreeable to be fairly effective as a means of defense. There is no foundation for the common juvenile belief that handling toads will make warts on a person's skin. The toad generally remains concealed under a stone or doorstep or other suitable object in the daytime, and begins active operations in the early evening. It catches earthworms, caterpillars, beetles, and other insects. The tongue is quite extensible, and is attached in front, the free tip lying back in the mouth. This arrangement allows it to be extended farther than it could be if it were fastened at the back, as the human tongue is. It is covered with a slimy, sticky secretion that causes an insect to stick to it when brought into contact with it. The toad catches insects by darting its sticky tongue out upon them. It is a very skillful marksman, and 
seldom misses its aim. Collectors of insects often examine the stomachs of toads, finding in them some kinds of beetles the collectors themselves have overlooked. Every toad is a valuable assistant to crop growers, and it should not be killed, except when needed for other purposes. Upon the approach of winter, frogs and toads conceal themselves either in the mud at the bottom of a pond, or in a hole in the ground. Here they remain all winter, without eating, or breathing very much. On the approach of spring, they come out of their winter quarters prepared for another summer's activity. Stories of living toads having been found embedded in rocks, where they have lain for thousands of years, are probably all untrue. None have been satisfactorily authenticated.

\section{The Tadpole.}

1. Notice the shape of the body. In what direction (laterally, or vertically,) is the tail flattened?

2. See the mouth. Is it large or small? Has the tadpole eyelids? Has it legs?

3. Notice the intestine. Cut through the body wall and examine it. How long is it? Is it longer, or shorter, than the intestine of a frog? Remove it.

4. See the gills. How many? Draw.

5. Find the heart. Trace the artery to see whether it goes to the gills or to the system. How many chambers has the heart?

6. Examine a large tadpole. Which pair of legs begins to grow first? What becomes of the tail? What do tadpoles eat?

7. What is the difference between toad tadpoles and frog tadpoles?

8. What is the difference between toad eggs and frog eggs? 
Make a table of differences between a frog and a tadpole. After this has been made, make another column to the table for the statement of the characteristics of a fish. In how many characteristics is the tadpole unlike the frog and like the fish? What is the strongest statement you can make about the similarities of the tadpole and the fish?

\section{1}

\begin{tabular}{|c|c|c|c|}
\hline & Frog. & Tadpole. & Fish. \\
\hline & frog-like & $\cdots \cdots$ & \\
\hline$\cdots$ & lungs...... . & $\cdots \cdots$ & $\cdots$ \\
\hline & large ......... & $\ldots \ldots \ldots \ldots$ & $\ldots$ \\
\hline ndages & 4 legs . ..... & $\ldots \ldots \ldots \ldots$ & $\cdots$ \\
\hline Tai & none $\ldots$. & $\ldots \ldots$ & $\ldots$ \\
\hline$\ldots \ldots$ & 3-cham ber & $\cdots$ & . \\
\hline on & double, incomplete. & $\cdots \ldots \ldots \ldots \cdots$ & $\cdots \cdots \cdots$ \\
\hline tion. & hop $\ldots \ldots \ldots \ldots \ldots$ & $\cdots \cdots \cdots \cdots \cdots$ & $\cdots \cdots \cdots \cdots$ \\
\hline 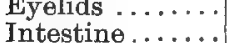 & two $\ldots \ldots \ldots \ldots \ldots$ & $\cdots \cdots \cdots \cdots \cdots \cdots$ & $\ldots \ldots \ldots$ \\
\hline Foo & carnivorous $\ldots \ldots \ldots$ & $\cdots \cdots$ & $\begin{array}{ll}\cdots \\
\cdots \cdots\end{array}$ \\
\hline Habitat. & land.............. & $\ldots \ldots \ldots \ldots$ & $\ldots \ldots \ldots$ \\
\hline
\end{tabular}

\section{Review Questions on the Frog.}

1. How many eyes has a frog? How many eyelids? With" which does it wink?

2. Is there a third eyelid?

3. Are the eyes movable?

4. Has the frog a neck?

5. Where are the nostrils? Do they open into the mouth?

6. Describe the ears. What is the white spot in the ear?

7. Has the frog teeth?

8. Where is the tongue attached?

9. Is the tongue forked or round?

10. Of what use is the tongue? How does the frog seize its food?

11. Is the skin covered? 
12. What is the difference between the fore and the hind legs?

13. How many toes on each foot?

14. What are the parts of the fore leg? Of the hind leg?

15. Is there a diaphragm?

16. Are there any ribs?

17. How does a frog breathe?

18. What organs in the body cavity?

19. What shape is the stomach?

20. How many lobes has the liver?

21. Is there a bile sac?

22. Is there a cloaca?

23. What tube leads air into the lungs?

24. Where is the larynx?

25. What is the size of the Jung cells?

26. How many chambers has the heart?

27. Describe the aorta.

28. What branches does the aorta give off?

29. What veins bring blood back to the heart?

30. How many venæe cavæ?

31. What veins unite to form each?

32. Name all the parts of the brain.

33. What nerves did you see?

34. How many spinal nerves?

35. How many roots has each nerve?

36. How many vertebræ?

37. Name the bones of the pelvic girdle.

38. Name the bones of the shoulder girdle.

39. How many condyles?

40. Where is the mylohyoid muscle?

41. What are the breathing organs of a tadpole?

\section{Von Baer's Principle.}

When the frog eggs are first laid, each consists of a single cell. Under proper conditions, the egg cell 
divides into two cells nearly equal to each other in size. These two cells divide again, thus forming four cells nearly equal in size. This process continues, each cell dividing into two, until the whole mass of the egg consists of many cells.

At this stage, and for some time afterward, there is nothing in the appearance of the egg itself that would indicate whether the egg is to develop into a vertebrate or into an invertebrate. Its vertebrate characteristics do not begin to appear until after it has manifested the characteristics of an invertebrate animal. In fact, we may say that at one stage of its existence, the tadpole, or frog, manifests all the characteristics of an invertebrate. For our present purpose, we may say that it passes through the same stages that a worm does, for we may take a worm as being a typical invertebrate.

Later, the vertebrate characteristics begin to appear, but it is not yet a frog. It begins to show red blood, a two-chambered heart, and gills, and blood goes from the heart to the gills just as it does in a fish. In fact, it is a fish. Afterward the four legs appear, while the tadpole still keeps its tail. If we compare the tadpole in this stage with the salamander, we see that the two are almost identical, both being tailed Batrachians. But the tadpole goes on to another stage. Its tail disappears and it becomes a frog.

We may arrange the steps as follows:-

Table of Stages in the Development of a Frog.

\begin{tabular}{|c|c|c|c|c|}
\hline $\begin{array}{c}\text { Single } \\
\text { Anlinal Cell. }\end{array}$ & Invertebrate. & Fish. & $\begin{array}{c}\text { Tailed } \\
\text { Batrachlan. }\end{array}$ & $\begin{array}{c}\text { Talliess } \\
\text { Batrachian. }\end{array}$ \\
\hline $\operatorname{Lgg} . . . . . .$. & worm ... & tadpole & salamander. . & frog . \\
\hline
\end{tabular}


If wo study the development of any animal, we find a similar series of changes, except that the development does not always stop with the batrachian. The rabbit, for example, begins as a single animal cell, an egg. It next shows the characteristics of an invertebrate, a worm. Then it comes to have a twochambered heart and rudimentary gills, like a fish. Next the heart becomes three-chambered and lungs ar'e developed, as in a frog or a turtle. There is so much resemblance between reptiles and batrachians that the two classes of animals are sometimes placed in one group. The reptile is the best type of this group, which would include batrachians, reptiles, and birds. We may say, then, that the rabbit, at one time in its history, is a reptile. But it does not stop here. The heart becomes four-chambered, its body becomes covered with hair, it acquires teeth, and comes to have the characteristics of a mammal.

Let us put these facts into a table:-

Table of Stages in the Development of a Mammal.

\begin{tabular}{c|c|c|c|c|}
\hline Single Animal Cell. & Invertebrate. & Vertebrate. & Reptile. & Mammal. \\
\hline Egg............ & worm......... & fish....... & reptile. & mammal... \\
\hline
\end{tabular}

This is called the Ontogenetic or Exirryologic SERIEs.

If we take all the animals that now exist and arrange them in the order of their complexity, placing the simplest first, we shall have another series.

The simplest animals are one-celled animals. They consist of a single animal cell, thus corresponding in complexity to an egg.

The next degree of complexity is represented by the invertebrates. This is a very large group 
of many degrees of complexity. As we have yet studied only one branch, we shall take the invertebrates as $a$ whole and let them be represented by a worm.

The simplest class of vertebrates is the fish. The next group of vertebrates, representing a greater degree of complexity, is the group which includes batrachians, reptiles, and birds. We may take the reptiles as representing this group.

The animals of greatest complexity are represented by the mammals, of which we take the rabbit as a type.

Arranging these living animals in a series, we shall have the following :-

\section{Table of Animals Now Living.}

\begin{tabular}{|c|c|c|c|c|}
\hline $\begin{array}{c}1 \\
\text { Protozoa. }\end{array}$ & $\stackrel{2}{2}$ Invertebrates. & $\begin{array}{c}3 \\
\text { Fishes. }\end{array}$ & Rejtiles. & $\stackrel{5}{\text { Mammals. }}$ \\
\hline Egg........ & worm ......... & fish.... & reptile..... & mammal... \\
\hline
\end{tabular}

This is called the ZoöLogic or Taxonomic Series.

Next, if we take the animals that have existed and arrange them in the order of their appearance upon the earth, we shall find that the first animals which appeared were undoubtedly protozoans. Each one consisted of a single animal cell. Therefore, they were comparable in complexity to an egg.

The next group of animals to appear were invertebrates. One great period of time is called the Age of Invertebrates. We may let the worm represent the animals which appeared at that time.

Another geologic period is called the Age of Fishes, which succeeded immediately the Age of Invertebrates.

Then followed the Age of Reptiles, and finally the Age of Mammals. 
Putting these facts into a table, we have another series :-

Table of Animals Arranged in the Order of their Appearance upon the Earth.

\begin{tabular}{|c|c|c|c|c|}
\hline $\begin{array}{c}1 \\
\text { Protozoa. }\end{array}$ & 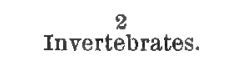 & $\stackrel{3}{\stackrel{3}{1}}$ Fishes. & $\stackrel{4}{{ }^{4}}$ & $\stackrel{5}{\vdots}$ \\
\hline$g g$ & worm ... & fish. & reptile.. & mammal \\
\hline
\end{tabular}

This is called the Geologic or Phylogenetic SERIES.

Now putting these Three SerIes together, we shall have the following arrangement:-

\begin{tabular}{l|l|l|l|l|l}
\hline $\begin{array}{c}\text { Ontogenetic or Em- } \\
\text { bryologic Series .. }\end{array}$ & egg ......... & worm & fish & reptile & mammal \\
\hline $\begin{array}{c}\text { Zoölogic or Taxo- } \\
\text { nomic Series..... }\end{array}$ & protozoan; egg & worm & fish & reptile & mammal \\
\hline $\begin{array}{c}\text { Geologic or Phylo- } \\
\text { genetic Series. ... }\end{array}$ & protozoan; egg & worm & fish & reptile & mammal \\
\hline \hline
\end{tabular}

We see that there is a complete correspondence in the three series. This is what makes men believe that the higher orders of animals in the history of the earth have been developed from the lower, and that each animal represents in its development (Ontogeny) the history of the race from which it is descended. This last statement is known as Von BaER's Principle. 


\section{CHAPTER VIII.}

\section{THE PIGEON.}

1. Identify the head, beak, and upper and lower mandibles. Can the upper mandible move without moving the skull?

2. Find the nostrils. Insert the head of a pin into the nostrils, to see where they open into the mouth.

3. Observe the swollen membrane, beneath which the nostrils open on the outside.

4. Find the tongue and notice its peculiarities. At the base of the tongue, notice an opening into the windpipe. It is the glottis.

5. See the eyes. How many eyelids do you find? The transparent one is the nictitating membrane. In what direction does it move? What is its use? Is there anything homologous to it in your own eye?

6. Find the ears. What peculiarity of the feathers around the ear? Draw the head.

\section{The Legs.}

1. The segment of the leg next to the body is the thigh. Its bone is the femur.

2. The bone of the leg, or drumstick, is the tibia.

3. The next part of the leg is the tarsus. Is it feathered? Which joint corresponds to the knee? Does a knee ever bend backward?

4. How many toes on each foot? How arranged? 
How many bones, exclusive of claw, in the hind toe? In the inner toe? Middle? Outer?

5. What is the covering of the toes and the tarsus?

\section{The Wings.}

1. Find three parts of the wing; viz., the arm, forearm, and hañd.

2. The large feathers growing on the liand are primaries. Those on the forearm are secondaries. If any large feathers grow on the arm, they are called tertiaries.

3. How many primaries are there? How many secondaries?

4. Observe that one side of the primaries is larger than the other. Which side overlaps? Why?

5. Find smaller feathers covering the bases of the primaries and secondaries. These are the wing coverts, upper and lower.

6. Find the thumb, which bears one primary, the spurious primary. Has it any coverts?

7. Count the tail feathers. Find the upper and lower tail coverts.

8. The bunches of large feathers on the shoulders are the scapulars.

\section{The Body.}

Pick the pigeon, preserving some of the feathers for future study. body?

1. Do you find anything besides feathers on the

2. Are the feathers arranged in rows, or are they scattered promiscuously over the body? Are there any places where there are no feathers? Can you recognize any down? Any pin feathers? What are pin feathers?

3 . See the oil gland on the dorsal side of the tail. What is its use? 


\section{The Internal Structure.}

1. Insert a tube into the mouth and inflate the crop. Carefully remove the skin and inflate again.

2. Loosen the crop from the neck and breast.

3. Find the windpipe, or trachea. Describe its structure.

4. On each side of the neck is a vein and a white cord. The cord is the pneumogastric nerve. The vein is the jugular vein.

5. Insert the tube into the glottis and inflate the lungs. Observe the swelling of the whole body, and the inflation of the thin-walled air sac in front of the breast bone. Other sacs can be seen just behind the breast bone.

6 . Find the ridge of bone along the breast of the pigeon. This is the keel of the sternum.

7. Cut the large muscle of the breast loose from the sternum. The muscle is the pectoralis major. Loosen it all around except at the front end. Find the white cord (tendon) by which it is attached in front. To what is it attached? What motion is produced when the pectoralis major is pulled?

8. Find the pectoralis minor, or subclavian muscle, directly under the pectoralis major. Loosen it, except in front. Trace the tendon to its insertion. What motion is produced when the pectoralis minor is pulled?

9. Scrape the flesh from the breast bone and from the bones in front. Find the wish bone. It consists of the homologues of two clavicles united. Remove it and draw.

10. Find the coracoid bones, extending from the sternum to the shoulder. What is the use of the coracoid bones and the clavicles?

11. Remove the sternum carefully, clean it, and draw. 


\section{Do you find a diaphragm?}

13. Find the gizzard. Describe it.

14. The part of the intestine nearest the gizzard is the duodenum.

15. In a long loop formed by the duodenum, find the pancreas.

16. Trace the intestine, tearing it loose from a thin, transparent membrane (mesentery) that holds it in place.

17. Find two very short side branches (cæca) near the end. In some kinds of birds the cæca are very long.

18. Find the cloaca, which is the widened termination of the intestine.

19. Find the glandular stomach, in front of the gizzard. See the osophagus leading into it.

20. Remove the glandular stomach, gizzard, and intestine. Examine the gizzard. Open it. Observe its contents and its lining. Of what use is the gizzard?

21. See the liver. How many lobes? Has it a gall bladder?

22. Can you find the spleen? This is a small red body attached to the right side of the crop.

\section{The Circulation.}

1. Find the heart. Notice the thin sac (pericardium) enclosing it.

2. Find the large artery, the aorta, running forward from the heart. What branches does the aorta give off, and where does each go? Toward which side of the pigeon does the aorta turn after leaving the heart?

3. The left subclavian is the name of the artery which goes to the left wing. The left carotid is the one which goes to the head. It branches off from the 
left subclavian. Find also the right subclavian and the right carotid. Trace the aorta backward, where it is called the dorsal aorta.

4. Find veins leading the blood to the heart. The one from the liver is the vena cava inferior. Find two others coming from the front, right and left venæ cavæ superiores.

5. Find the artery which carries the blood to the lungs. This is the pulmonary artery. Find veins which carry the blood back from the lungs. These are pulmonary veins. How many are there?

6. Cut off all the arteries and veins as far from the heart as you can. Identify the parts of the heart.

7. Find the two auricles, right and left. What tube enters each auricle?

8. Identify the two ventricles, right and left. What arteries leave each ventricle?

9. Make a complete drawing of the heart and blood vessels.

\section{The Reproductive Organs.}

1. In the back, find the oraries in the female, or two white oval bodies, the testes, in the male.

2. Find a tube leading from the reproductive organs to the cloaca. In the female, this is called the oviduct.

3. In the posterior part of the back, find the kidneys, two dark colored, irregular bodies. Find tubes leading from the kidneys to the cloaca.

\section{The Respiratory Organs.}

1. Find the trachea, or windpipe. Describe its structure. How many rings of cartilage has it?

2. Find the larynx, at the top of the trachea.

3 . Find the two bronchial tubes, at the bottom of the trachea. 
4. Find the syrinx, or lower larynx, at the place where the two bronchial tubes divide. The song of the bird is produced in the syrinx.

5. Inflate the lungs by means of a tube inserted into the trachea. Are the lungs free, or attached to the back? What holds them in place? What causes air to go in to the lungs?

\section{The Skull.}

1. Separate the head from the neck, and scrape as much flesh from it as you can.

2. Find the large hole at the base of the skull through which the spinal cord runs. This is the occipital foramen.

3. In front of the occipital foramen, find a roundish, convex knob or surface. This is the occipital condyle. Is there one, or more than one?

4. See how the lower jaw joins the skull. The very small bone by which the lower jaw articulates with the skull is the quadrate bone.

5. Find a slender bone along the lower edge of the upper mandible. This is the jugal or maxillary bone. Where is it attached at each end?

6. When the lower jaw is depressed, what effect does the motion have upon the quadrate bone? Upon the jugal bone? Upon the upper mandible?

7. Draw the skull, showing all the above mentioned parts.

8. Separate two or three vertebræ from the nock. Clean and draw them.

\section{The Nervous System.}

1. Find the spinal cord in the neck. Do you find the roots of any nerves?

2. Look into the body cavity, near the backbone, 
between the ribs, for nerves. How many pairs do you find?

3. Find nerves leading from the spinal cord to the wings, and to the legs. How do these nerves compare in size with other spinal nerves?

4. Slice off the top of the skull and expose the brain. Make out the following parts: the cerebrum, in front, consisting of two lobes separated by a deep groove; the cerebellum, undivided, behind; the optic lobes, at the sides, below the cerebrum and cerebellum.

5. Lift up the brain and see the optic nerves running to the eyes. Do they cross? Do they unite with each other?

6. Draw the brain.

\section{The Feathers.}

1. Study one of the large wing feathers. The hollow rounded part is the calamus, or quill. The expanded part is the vane. The central portion of the vane is the rhachis. The small divisions on each side of the rhachis are the barbs.

2. Examine a few of the barbs. See the barbules, interlacing between the barbs. These hold the barbs in position.

3. Do you find any barbules on the down?

4. Draw a feather.

\section{An Egg.}

1. Note the shape, size, and smoothness of the shell. Are the two ends alike?

2. Break the shell and examine the lining. Of how many layers is the lining composed? In which end is the air bubble?

3. Is the "white" all alike, or is there more than one kind? 
4. Observe a thin membrane, the vitelline membrane, around the yolk.

5. Notice two twisted strings, the chalazæ, running from the vitelline membrane in the white.

6 . In the yolk, notice the nucleus. Does it extend clear through?

7. In the nucleus, see the nucleolus.

Make a table showing differences between a pigeon and a fish, thus :-

\begin{tabular}{|c|c|c|}
\hline & Fish. & Pigeon. \\
\hline Covering............. & $\ldots \ldots$ & $\cdots$ \\
\hline 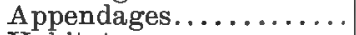 & $\ldots \ldots \ldots \ldots \ldots \ldots$ & $\ldots$ \\
\hline Habitat............. & $\ldots \ldots \ldots \ldots$ & . \\
\hline Locomotion............. & $\ldots \ldots \ldots \ldots$ & $\ldots$ \\
\hline Heart. .............. & $\ldots \ldots \ldots$ & $\ldots \ldots \ldots$ \\
\hline Circulation............ & $\ldots \ldots \ldots \ldots \ldots \ldots$ & $\ldots \ldots \ldots \ldots \ldots \ldots$ \\
\hline Breathing........... & $\ldots \ldots \ldots \ldots \ldots$ & $\ldots \ldots \ldots \ldots \ldots \ldots$ \\
\hline Temperature........... & $\ldots \ldots \ldots \ldots \ldots \ldots$ & $\ldots \ldots \ldots \ldots \ldots \ldots$ \\
\hline Eggs................ & $\ldots \ldots \ldots \ldots \ldots$ & $\ldots \ldots \ldots \ldots \ldots$ \\
\hline
\end{tabular}

\section{Review Questions on the Pigeon.}

1. What is the beak?

2. Of what is the beak composed?

3. How does the mouth open?

4. What is peculiar about the tongue?

5. Where are the nostrils?

6. Into what do the nostrils open?

7. What and where is the glottis?

8. How many eyelids?

9. Where is the third eyelid fastened?

10. What is there in our eyes that is homologous to the third eyelid?

11. Where are the ears?

12. What is peculiar about the feathers around the ears? 
13. What is peculiar about the ear itself?

14. Name the parts of the leg.

15. Between what bones is the knee?

16. Where is the heel?

17. Is the tarsus feathered?

18. With what is the tarsus covered?

19. How many bones, exclusive of the claw, in the hind toe? Inner toe? Middle toe? Outer toe? 20. Name the parts of the wing.

21. What feathers grow on the hand? On the arm? On the forearm?

22. What and where is the spurious primary?

23. How many bones in the forearm?

24. How many bones in the hand?

25. How many primaries has a pigeon?

26. How many secondaries?

27. What are the coverts?

28. How many tail feathers?

29. Where are the tail coverts?

30 . Where are the scapulars?

31. How are the feathers arranged?

32. What are pin feathers?

33. What homologues of feathers are also found?

34. Where is the oil gland? What is its use?

35. What is the windpipe? Of what is it composed?

36. Where is the crop? What is its use?

37. What veins run down the neck?

38. What arteries run up the neck?

39. What nerve runs up the neck?

40. What are the air sacs? How many did you count?

41. What and where is the sternum?

42. What bones are joined to the front end of the sternum?

43. To what is the wish bone homologous?

44. What and where is the scapula?

45. What muscle moves the wing up? 
46. What muscle moves the wing down?

47. What is a tendon?

48. To what bone is the tendon of the pectoralis minor attached? At what place on the bone is it attached?

49. Has the pigeon a diaphragm?

50. How many ribs?

51. What difference between the bones of the neck and the bones of the back?

52. What is the pericardium?

53. What is the principal artery leaving the heart?

54. From which end of the heart does it go?

55. In what direction does it turn?

56. What is the first branch of the aorta?

57. To what organ does the left subclavian artery carry blood?

58. What is the first branch it gives off?

59. What is the second branch of the aorta?

60 . To what does the right subclavian carry blood?

61. What is its first branch?

62. To what other organ does the aorta carry blood?

63. What veins bring blood back to the heart?

64 . What tubes open into the cloaca?

65. How many chambers in the heart?

66. What and where is the occipital condyle?

67. What and where is the quadrate bone?

68. Name all the parts of an egg.

69. Name all the parts of a feather.

\section{Additional Facts About Birds.}

Birds are distinguished from all other animals by being almost completely covered with feathers. We can see, however, that on some birds the tarsus is covered with scales instead of feathers. So it seems quite evident that in some way the feathers take the place of scales. Feathers are therefore homologous 
to scales. That is, the same thing which is developed on the fish as scales is developed on the hird as feathers.

Among the feathers will be found hairs. The hairs are scattered among the feathers, being clustered together in some instances around the mouth and ears. Since they have the same position as feathers, we are compelled to believe that feathers and hairs are homologous structures.

This covering of the body which may be developed as scales, feathers, or hairs, constitutes what may be called the exoskeleton. It is composed of a substance called keratin, one ingredient of which is sulfur. A pigeon, then, has redly two skeletons, an exo- and an endo-skeleton, although when we speak of the skeleton of a bird we always mean the endoskeleton.

The wings are highly specialized organs, adapted for flight. The large feathers, the primaries, are arranged in such a way that the short barbs of one primary overlap the longer and less stiff barbs of the other side of the next feather. This arrangement makes a firm surface for the downward stroke, but allows the passage of air between the feathers much more readily when the wing is rising.

The muscles that move the wing are very curious. Two muscles, pectoralis major and pectoralis minor, lying side by side, produce directly opposite motions of the wing when they contract alturnately. The tendon of the pectoralis minor passes directly over the end of the humerus, and is attached to the upper side of the same bone. This constitutes a pulley, and changes the direction of the motion. It pulls the wing upward. The pectoralis major passes orer no pulley, so its contraction pulls the wing downward.

The pectoralis major is much larger than the pectoralis minor. This is readily associated with the fact 
that it is the downward stroke of the wing, caused by the contraction of the pectoralis major, which raises and supports the bird in the air, while the action of the pectoralis minor does nothing but bring the wing into position for another downward stroke.

The strong, deep keel on the sternum furnishes a place for the attachment of these muscles. In kinds that do not fly, such as the ostrich, the sternum is not keeled, and the pectoralis muscles are not strongly developed.

No living bird has any teeth. The jaws are encased in a horny beak. Some fossil birds, among the earliest birds that lived, had teeth, and rudiments of teeth have been found in some embryonic birds.

The heart is four-chambered, and the circulation is double and complete. The aorta, instead of sending off two branches, right and left, as in the frog; bends to the right. That is, it retains only the right branch. The bodily temperature is constant, and about 104 degrees $F$.; so the bird is said to be warm blooded.

The breathing is by lungs, which are attached to the back. There is no diaphragm, but the movement of the ribs and abdominal walls serves to enlarge the cavity of the chest and so causes the air to rush into the lungs.

Besides the lungs, the pigeon has a series of accessory air sacs which serve not only to furnish more air to the body, but to make it lighter in-relation to its size.

Everything about the bird seems to have reference to its power of flight. Flying is the characteristic motion of birds, and the body is built with especial reference to that fact. The long bones are hollow and without marrow. The bones of the skull are filled with air spaces. Feathers are the lightest possible 
covering, and the largest flying bird is much smaller than the largest land or water animal.

The eggs of birds are remarkable for their very large size in comparison with those of other animals. The greater part of the egg consists of food for the embryonic bird. The egg begins to divide at the nucleus, as all other eggs do, but the planes of segmentation do not extend entirely through the body of the egg, as they do in the eggs of the frog and of some other animals. The segmentation is confined to a small portion of the egg which is called the germinal disc, and the body of the bird is formed from the cells thus produced. The remainder of the egg is absorbed as food, or nourishment, by the embryonic bird.

This kind of segmentation is called partial, or meroblastic segmentation.

The usual method of incubation is for the bird to sit upon the egg. The side of the egg upon which the germinal disc, or white spot, lies is apparently of less specific gravity than the opposite side. This is shown by the fact that in about nine out of every ten eggs that are broken, the germinal disc appears upon the upper side, and it takes careful and persistent effort to turn the yolk over so that the germinal disc will not show. The germinal disc is upon the upper side of the egg. This position brings it nearest the body of the sitting bird, which is the source of warmth, and this is the most favorable condition for the growth of the embryo.

An air space is usually found in an egg. The air space arises in the following way: When the egg is laid, it is of the same temperature as the body of the bird. It very soon cools, and its contents are thereby contracted. The shell, however, being rigid, cannot contract, so air is drawn in through the pores of the shell. The air space is found in the large end, because 
this is the most porous portion of the shell, and here, for some reason, the membranes are most easily separated. Subsequent increase in the size of the air space is due to the evaporation of water from the egg.

Some birds migrate. Their lives depend upon obtaining a sufficient supply of food at every season of the year. When the food of a bird disappears upon the approach of winter, as cloes the food of most insect-eating birds, the bird is compelle'd to go to some place where food can be obtained. Woodpecker's do not necessarily migrate, for their food is obtained from insects found in dead trees. These are quite largely available all winter. Ducks and geese inust migrate from the north, for the water, to which their habits of life adapt them, becomes frozen over.

There are usually considered about eighteen orders of birds.

\section{THE TURTLE.}

1. Chloroform the turtle. Cut off its head.

2. Examine the shell. The upper part is the carapace. The lower part is the plastron. Of how many plates is each composed? How are they united?

3. Saw through the union of the carapace and plastron? Cut the skin loose from the plastron, all around, and remove the plastron.

4. See the stomach. Trace the intestine to the cloaca.

5. Notice the heart in its pericardium. Usually the heart will beat for an hour or two after the turtle has been chloroformed and its head cut off.

6. Trace the aorta. Does one branch, or two, persist? If two, which is the larger?

7. Look at the lungs. Is there a diaphragm? How are the lungs held in place? 
8. Sec the reproductive organs. If it is near the breeding season, large eggs are likely to be found in the ovaries.

9. See the large retractor muscle, by means of which the head is drawn into the shell.

10. Observe the mode of attachment of the neck to the carapace. How many vertebræ in the neck? Clean one and draw.

11. Examine the skull. How rnany occipital condyles? Is there a third eyelid? Has the turtle any teeth? What is the nature of the jaws?

12. Observe the fore leg. What is the covering of the feet? How many toes on the fore leg?

13. Identify the scapula and the clavicle.

14. Study the hind legs. How many toes on each hind leg? How is the pelvis attached to the carapace?

15. Are there any ribs? Of what is the carapace composed? How many plates or bones can be counted on the inside of the carapace?

16. How many bones in the tail? How is the tail united to the carapace?

17. Of how many layers is the carapace composed? Is the outer layer of the same material as the inner layer?

Make a table showing resemblances between a pigeon and a turtle, as follows:-

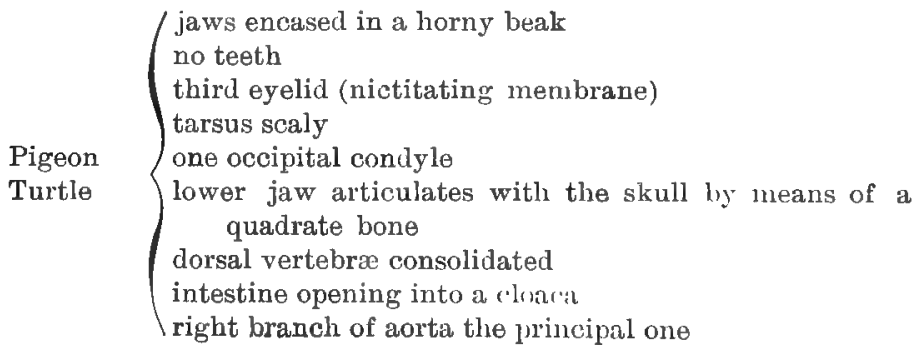




\section{Additional Facts About the Turte.}

Notwithstanding the very unlike appearance of the pigeon and the turtle, an arrangement of their resemblances shows that birds and reptiles are very closely allied. So close is the relation between them that Mr. Huxley puts birds and reptiles into one class, which he calls Sauropsida. The resemblances are so important that they seem explainable only on the hypothesis that birls have descended from some form of Reptilia, although not from turtles or suakes.

The most reptile-like orders of birds are extinct and known only by their skeletons. The most birdlike orders of reptiles are also extinct, so the living birds and living reptiles are very unlike each other. One of the earliest birdlike forms that ever existed is called the Archoeopteryx. It has been found as a fossil skeleton in some limestone beds in Germany. The accompanying figure shows how Mr. Shufeldt thinks it must have looked. It is difficult to decide whether a creature like this should be called a reptile or a bird.

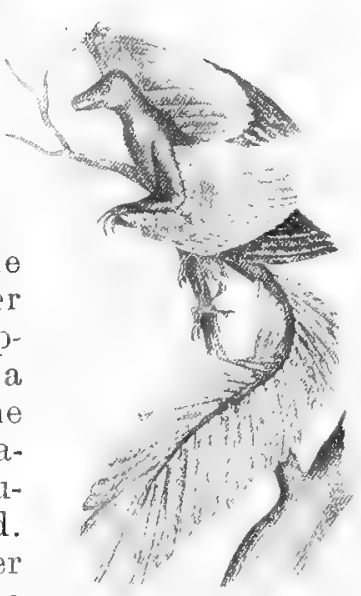

ARCH ECIPTERYX ( AFTEH SHUFELUT).

The characteristic feature of the turtle is the shell. This is composed of the vertebra of the back, which are solichified together; of the expanded and consolidated ribs; and of the exoskeleton, which, in the turtle, is devcloped as horny plates and consolidated with the internal skeleton. The vertebræe of the pigeon's back are also consolidated, but for a different 
purpose. In the pigeon the consolidated vertebræ furnish a more solid support for the wings, while in the turtle the consolidation of the vertebræ into the shell furnishes a protection for the animal.

The corpuscles of the blood are nucleated, and the turtle is cold blooded.

The eggs of the turtle are large, like those of birds, and contain much white surrounding the large yolk. In some species of turtles, the egg has a calcareous shell, as in birds, while in others the shell is not calcareous.

There are four orders of living reptiles :-

Chelonia-turtles.

Ophidia-snakes.

Lacertilia-lizards.

Crocodilia-alligators and crocodiles.

There are six orders of reptiles that are extinct.

The snakes and crocodiles represent the extreme forms of the orders. 


\section{ZOOLOGICAL LABORAIORY, MicGRAW HALL}

\section{CHAPTER IX.}

\section{THE RABBIT.}

1. Examine the legs. Look at the soles of the feet. How many toes on each foot? Which pair of legs is the longer?

2. Note the length and position of the ears.

3. Observe the whisker's on the upper lip. Notice the nostrils and the cleft in the upper lip.

4. Find the third eyelid, or nictitating membrane. Compare it with that of the pigeon. Is it functional or vestigial?

5. Notice the inside of the cheek.

\section{Internal-Structure.}

1. Skin a rabbit and slit through the abdominal walls as far forward as the diaphragm.

2. Identify the intestine the liver and the stomach.

3. Examine the stomach. Notice its shape and size. Find the cesophagus, entering it, and the intestine, leaving it.

4. How many lobes to the liver? Find the gall bladder. Can you find a tube leading from the gall bladder to the intestine?

5. The part of the intestine just behind the stomach is the duodenum. The irregular mass within the loop is the pancreas.

6. Notice the mesentery. This is the thin membrane which holds the coils of the intestine together. 
Separate the intestine from the mesentery. Find where the mesentery is attached to the body.

7. Notice the place at which the small intestine sets into the large intestine. The part of the large intestine beyond this point is the crecum. How long is it?

8. Remove the intestine from the abdomen. Find the dorsal aorta running along the backbone.

9. Find a branch of the aorta going to each kidney-the renal arteries, right and left. Do both leave the aorta at the same place?

10. Find a division of the aorta going to cach hind leg. These are the right and left common iliac arteries.

11. Find the vena cava inferior, running toward the heart parallel to the aorta.

12. Find the iliac veins, coming from the hind legs, which veins, by their union, form the inferior vena cava.

13. Can you find the portal vein, entering the liver? This vein is formed by the mesenteric vein, the splenic vein, from the spleen, and the gastric vein, from the stomach.

14. Can you find the hepatic vein, from the liver, emptying into the inferior vena cava?

15. Examine the diaphragm. The thin, transparent portion in the middle is the tendon. Of what is the diaphragm composed? What is its use?

\section{Organs of the Thoracic Cavity.}

1. Cut through the ribs on eacl side and open the thorax. Identify the heart and the pericardium onclosing it.

2. Find the auricles.

3. Trace the aorta. Does it bend to the right or to the left? What branches does it give off?

4. Identify the following arteries:-

(a) The right subclavian, carrying blood to the right fore leg. 
(b) The right and left common carotids, sending blood to the head. They are called common carotids because each divides into an external carotid, carry. ing blood to the outsicle of the head, and an internal carotid, carrying blood to the brain and inside of the head. From what artery do these spring? Do they leave the artery separately or together?

(c) The left subclavian, carrying blood to the left fore leg.

5. Trace the aorta until it becomes the dorsal aorta, previously seen.

6. Find on each side of the neck a large vein, the jugular vein. Trace it towards the heart until it unites with a vein from the left fore leg, the subclavian vein.

7. The union of the jugular and the subclavian veins forms the superior vena cava. Find one on each side of the body.

8. Cut off the arteries and veins as far from the heart as you can, and remove the heart and lungs from the thorax. What holds the lungs in place?

9. Notice the trachea. Find the larynx, at the top. How many rings has the trachea? Do the rings go entirely around? What is the position of the cesophagus, with reference to the trachea?

10. Notice the bronchial tubes. Where does each lead?

11. Find the pulmonary artery, leading from the heart to the lungs. Find where it branches to each lung.

12. Find the pulmonary veins, leading from the lungs to the heart. How many?

13. Identify the right and left auricles and the right and left ventricles. With which chamber of the heart does each artery and each vein that you have seen communicate?

14. Make a complete diagram of the circulation of the rabbit. 


\section{The Head.}

1. Remove the skin from the head. Below and back of the ear, find an irregular pink mass, the parotid salivary gland.

2 . In the angle between the branches of the lower jaw, find two roundish bodies, the submaxillary salivary glands.

3. See the muscle which covers the back part of each side of the lower jaw. This shuts the mouth. Where is it attached? Cut it away.

4. Thoroughly clean the lower jaw and examine the teeth. The front ones are incisor's. Those farther back are molars. How many of each kind in the upper jaw? How many of each kind in the lower jaw?

5. How is the lower jaw attached to the skull? Draw the lower jaw.

6. Find the occipital foramen, through which the spinal cord passes into the skull.

7. In front of the foramen, find the two occipital condyles. Thoroughly clean the first two vertebræ of the spinal column. The first one is the atlas, the second one is the axis. How do they differ?

\section{Interior of the Head.}

1. Cut away carefully the top and back of the skull, exposing the brain. Find two coverings, one closely attached to the skull, the other covering the surface of the brain. The first one is called the dura mater, and the second one is called the pia mater.

2. Identify the cerebrum. Notice the groove between the two lobes.

3. See the band of white fibers connecting the two lobes.

4. Identify the cerebellum, behind and under the cerebrum. 
5. Find the medulla oblongata, which is the part of the brain within the skull that is continuous with the spinal cord. lobes.

6. In front of the cerebrum, find the two olfactory

7. Lift up the front of the brain and see the cranial nerves. Find the optic nerves and trace them to the eyes. Do the nerves cross?

8. How many pairs of cranial nerves can you discover?

\section{Spinal Cord.}

1. Cut through the vertebræ, unroofing the cavity in which the spinal cord lies. See the covering of the spinal cord.

2. See the roots of the spinal nerves. Notice that the nerves go off in pairs, a right and a left, and that each nerve has two roots, an anterior and a posterior, or upper and lower.

3. Find a ganglion, on the posterior root just before it joins the anterior one.

4. Inside the body cavity, between the ribs, look for continuations of the spinal nerves. How many pairs of spinal nerves can you discover?

5. Find the large nerves that go to the fore legs. Notice the size of the spinal cord at the place in which these nerves originate.

6. Find the large nerves that go to the hind legs. The principal nerve down the leg is the sciatic nerve. Trace it.

\section{'The Legs.}

1. Separate from the body the entire skeleton of the fore leg, including the shoulder blade. Is it connected by a joint to the backbone? What holds it in place?

2. Clean all the muscle away from the bones.

3. Identify and draw all the bones you can find. 
4. See the ligaments which hold the bones together.

5. See the cartilage which covers the ends of the bones.

6. Feel the slippery surface of the end of one of the large bones. Synovia, or joint water, renders it slippery.

7. Find a lining over the bones, completely covering them. This is the periosteum.

8. Study the muscles on the hind leg. Separate one muscle from all the others. Study it.

9. Notice the muscle sheath, a very thin, transparent membrane over all the muscle.

10. Note the tendon, a tough white cord at the end of the muscle. Find the place in which the tendon is attached to the bone. The place of attachment which is nearest the central part of the body is called the origin. The attachment at the other end is called the insertion.

11. Separate a small part of muscle into stringy pieces as small as you can. The finest pieces into which you can separate it are called muscle fibers.

12. A muscle fiber, when highly magnified, shows short markings across it. These markings are called striations, or striæ. Voluntary muscles, or those under control of the will, are all composed of striated fibers. So is the heart, which is an involuntary muscle. It is probable that striations are more closely associated with the frequency and vigor of contraction than with its voluntary or involuntary character.

\section{Review Questions on the Rabbit.}

1. What is the covering of a rabbit?

2. What is its color? Is this color an advantage?

3. Tell of the length and color of the tail. Is this color of any use? 
4. In what direction do the ears point?

5. How many toes on the hind foot? On the front foot?

6. What is peculiar about the soles of the feet?

7. What peculiarity has the upper lip?

8. Is there a third eyelid?

9. How many incisors in the lower jaw?

10. How many incisors in the upper jaw? How are they arranged?

11. How many molars in the right side of the upper jaw?

12. How many in the right side of the lower jaw?

13. Of what use are the whiskers?

14. What two cavities in the body? What separates them?

15. What organs are found in the abdominal cavity?

16. What are the digestive organs?

17. What is the mesentery?

18. What organs are in the thoracic cavity?

19. Trace the aorta, naming all branches you have seen.

20. From what part of the heart does the aorta spring?

21. In what direction does the aorta bend?

22. What veins carry the blood back to the heart?

23. Name the branches which make up each vena cava.

24. What part of the heart do the venæ cavæ enter?

25 . What artery carries blood to the lungs?

26. From what part of the heart does it spring?

27. What veins bring blood back to the lungs?

28. How many pulmonary veins enter the heart?

29. Name all the parts of the heart.

30. What is the pericardium?

31. How many lungs? What is their function?

32. What muscles are used in breathing?

33. What tube carries air to the lungs?

34. How many rings in the trachea?

35. Of what are the rings composed?

36. Do the rings go entirely around? 
37. What are the bronchial tubes?

38. What is the larynx?

39. What are the parts of the brain?

40. Which is the largest part?

41. How many cranial nerves did you see?

42. Do the optic nerves cross?

43. Where is the spinal cord?

44. How many pairs of spinal nerves?

45. How many roots has each nerve?

46. On which root is the ganglion?

47. How many ribs lias the rabbit?

48. What are the vertebræ?

49. How many vertebræ has the rabbit?

50 . What are the names of the first two vertebræ of the neck?

51. How many condyles?

52. Of what use are the condyles?

53. What shape is the lower jaw?

54. How is the lower jaw attached to the skull?

Make a table showing the differences between a fish, frog, pigeon, turtle, and rabbit, thus:

\begin{tabular}{|c|c|c|c|c|c|}
\hline & Fish. & Frog. & Pigeon. & Turtle. & Rabbit. \\
\hline Breathing ........... & & $\cdots$ & & & \\
\hline Habitat.... & $\ldots \ldots \ldots$ & $\ldots \ldots \ldots$ & $\ldots \ldots \ldots$ & $\ldots \ldots$ & $\ldots \ldots \ldots$ \\
\hline Appendages.......... & $\ldots \ldots$ & $\ldots \ldots \ldots$ & $\ldots \ldots \ldots$ & $\ldots \ldots \ldots$ & $\ldots$ \\
\hline Heart .............. & $\ldots \ldots \ldots$ & $\ldots \ldots \ldots$ & $\ldots$ & $\ldots \ldots \ldots$ & $\ldots$ \\
\hline Circulation........... & $\ldots \ldots \ldots$ & $\cdots$ & $\cdots$ & $\ldots \ldots$. & $\ldots$ \\
\hline 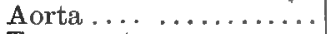 & $\ldots$ & $\ldots \ldots \ldots$ & $\ldots \ldots \ldots$ & $\ldots \ldots \ldots$ & $\ldots$ \\
\hline Temperature ......... & $\ldots \ldots \ldots$ & $\ldots \ldots \ldots$ & $\ldots \ldots \ldots$ & $\ldots \ldots \ldots$ & $\ldots$ \\
\hline Blood corpuscles ...... & $\ldots \ldots \ldots$ & $\ldots$ & $\ldots \ldots \ldots$ & $\ldots$ & . \\
\hline 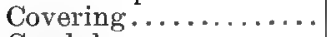 & $\ldots \ldots$ & $\ldots \ldots \ldots$ & $\ldots \ldots \ldots$ & $\ldots \ldots$ & $\cdots$ \\
\hline 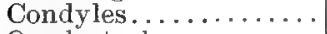 & $\ldots \ldots \ldots$ & $\cdots \ldots \ldots$ & $\ldots \ldots \ldots$ & $\ldots$ & $\cdots$ \\
\hline Quadrate bone........ & $\ldots \ldots \ldots$ & $\ldots$ & $\ldots$ & . & $\ldots$ \\
\hline Reproduction.......... & $\ldots \ldots \ldots$ & $\ldots \ldots$ & $\cdots \cdots$ & $\cdots$ & $\cdots$ \\
\hline Eggs $\ldots \ldots \ldots \ldots \ldots \ldots$ & $\ldots \ldots \ldots$ & $\ldots \ldots \ldots$ & $\ldots \ldots$ & $\ldots \ldots$ & $\cdots$ \\
\hline 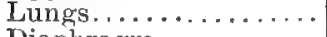 & $\ldots \ldots \ldots$ & $\ldots \ldots \ldots$ & $\ldots \ldots \ldots$ & $\cdots \cdots \cdots$ & $\cdots \cdots$ \\
\hline 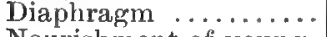 & $\ldots \ldots \ldots$ & $\ldots \ldots$ & $\ldots \ldots \ldots$ & $\ldots \ldots \ldots$ & $\cdots$ \\
\hline Nourishment of young. & " & $\cdot 1$ & $\cdots$ & $\ldots \ldots \ldots$ & $\cdots$ \\
\hline
\end{tabular}


Make a table of resemblances between the fish, frog, pigeon, turtle, and rabbit, as follows:-

Fish
Frog
Pigeon
Turtle
Rabbit $\quad \begin{aligned} & \text { red blood } \\ & \text { internal, bony, jointed skeleton } \\ & \text { brain and spinal cord enclosed in separate bony cavity } \\ & \text { two movable simple eyes } \\ & \text { two pairs of paired appendages } \\ & \text { jaws move vertically }\end{aligned}$

An animal which has the characteristics enumerated in this table is called a vertebrate.

Make a definition of a vertebrate. What is the predicate noun you must use?

From your table of differences between the vertebrates you have studied, make a logical definition of a mammal. What is the predicate noun you must use?

When you say "A mammal is a vertebrate," what do you mean?

What is included in the term vertebrate?

Make a table of differences between a grasshopper and a rabit, as follows:-

\begin{tabular}{|c|c|c|}
\hline & Grasshopper. & Rabbit. \\
\hline Skeleton ........... & $\ldots \ldots \ldots \ldots \ldots$ & $\ldots \ldots \ldots \ldots \ldots \ldots \ldots$ \\
\hline 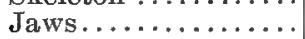 & $\ldots \ldots \ldots \ldots \ldots \ldots$ & $\ldots \ldots \ldots \ldots \ldots \ldots$ \\
\hline Eyes ............. & $\ldots \ldots \ldots \ldots \ldots \ldots$ & $\ldots \ldots \ldots \ldots \ldots \ldots \ldots \ldots$ \\
\hline Body $\ldots \ldots \ldots \ldots \ldots$ & $\ldots \ldots \ldots \ldots \ldots \ldots$ & $\ldots \ldots \ldots \ldots \ldots \ldots$ \\
\hline$\ldots \ldots \ldots \ldots$ & $\ldots \ldots \ldots \ldots \ldots \ldots$ & $\ldots \ldots \ldots \ldots \ldots \ldots$ \\
\hline Breathing....... & $\ldots \ldots \ldots \ldots$ & $\ldots \ldots \ldots \ldots \ldots \ldots$ \\
\hline Appendages......... & $\ldots \ldots \ldots \ldots \ldots \ldots \ldots$ & $\ldots \ldots \ldots \ldots \ldots \ldots$ \\
\hline Antennx $\ldots . . . \ldots$ & $\because \cdots \cdots \cdots \cdots \cdots$ & $\ldots \ldots \ldots \ldots$ \\
\hline Nervous system & $\left\{\begin{array}{c}\text { double nerve cord } \\
\text { and ganglia .... }\end{array}\right\}$ & brain and spinal cord. \\
\hline Position of nerves .... & $\left\{\begin{array}{c}\text { in same cavity as } \\
\text { other organs ... }\end{array}\right\}$ & $\begin{array}{l}\text { enclosed in a separate } \\
\text { bony cavity }\end{array}$ \\
\hline Reproduction ... & $\ldots \ldots \ldots \ldots \ldots$ & $\ldots \ldots \ldots . . . .$. \\
\hline Body divisions .. & $\ldots \ldots \ldots \ldots \ldots \ldots \ldots$ & $\ldots \ldots \ldots \ldots \ldots \ldots \ldots$ \\
\hline
\end{tabular}




\section{Additional Facts About the Rabbit.}

The rabbit is taken to represent the class Mammalia. All animals of this class nourish their young on milk, which is secreted by the mammary glands.

The rabbit belongs to an order of mammals which are called rodents. The name Rodentia is given to this order because the animals are great gnawers. Rats, mice, squirrels, beavers, etc., belong to this order. There are four incisors in the upper jaw of the rabbit, but one pair, which is very small, is placed behind the other pair. The incisor teeth grow throughout life, so that the part of a tooth that is worn away by excessive gnawing is soon replaced by growth at the base.

Rabbits have no canine teeth. In the dog, cat, and other carnivorous animals, the canine teeth are very large and are used for seizing prey. Such animals invariably eat meat as a part or all of their food.

If we knew nothing of the food of the rabbit, we should judge from the absence of the canine teeth that it did not eat meat, and did not prey upon other animals.

Rabbits often do injury to fruit trees, by gnawing the bark. When rabbits become very numerous, they eat so much of the vegetation that other animals find it hard to get enough to eat. In this way, rabbits have become a very great pest in Australia.

About 1860, a gentleman from England, who had settled in Australia, thought what a nice thing it would be to have some rabbits nuar his home, as he formerly had in England. He sent to England for a dozen pairs and turned them loose. They multiplied so rapidly that the Australian government and Australian farmers have spent millions of dollars in trying to exterminate them. It is estimated that the loss to 
farmers caused by rabbits in ten years in the single province of New South Wales, was $\$ 15,000,000$.

Likewise, in some parts of California, rabbits have become a pest.

Any animal, no matter what it is, unless. killed by some other means than a natural death from old age, will multiply so rapidly as to eat up all the food that, a country can furmish, and so exclude or drive out all other animals that depend upon the same kind of food. The rabbit is preyed upon by other animals, it is frozen to death in winter, and it is starved in snowdrifts, or when its food is all covered with snow; but the rains in the spring afford, probably, the most efficient check upon the number of rabbits in the greater part of the United States.

Rabbits produce seven to nine young at a birth, and usually in the early spring. The young are commonly born in a bed made in a shallow depression in the ground. If a heary, dashing rain comes about the time that the young are in this form, it is very probable that all or nearly all will be drowned.

Rabbits and other animals are subject to various diseases which operate as checks upon their rate of increase. The tapeworm is a very common parasite among rabbits. In one lot of ten dozen rabbits examined by the writer, forty-two were found to be infested with tapeworm. This, however, is a very large percentage to be so infested.

Sometimes, when an animal or a plant is carried from one country to another, the diseases, enemies, or other checks that prevented its rapid increase at home are not carried with it. Being freed from the checks that restrained it at home, it multiplies so rapidly as to become a serious evil. Such is probably the case with the gypsy moth mentioned on page 37. Such is the case with the San Jose scale insect, which has been very destructive to orange groves in California. In such a 
case, the remedy is to import a check if that is possible. This has been done in the case of the fluted scale, Icerya purchasi. Certain lady bugs which preyed upon it in its original home, Australia, were brought to the United States, and the fluted scale no longer threatens the welfare of the orange growing industry.

This tendency of an animal to increase faster than its food can increase is called The Pressure upon Subsistence. Since there cannot be food enough for all, each animal may be said to struggle to get enough to eat. The struggle, however, is not merely a struggle for food. It is a struggle to survive, notwithstanding all the checks upon multiplication of its numbers. This whole struggle, - struggle for food, struggle to escape from enemies, struggle to live through diseases, is called The Strugcte For Existence.

It seems very evident that not all will survive. Those that do survive are likely to be the individuals that in some way are best adapted to overcome the various difficulties they encounter: to escape from their enemies, by flight, fight, or concealment; to recover from discase or to escape contagion; to gather more food or to live upon less. The fact that those who do survive are best adapted to the conditions under which they live, supports what is known as the theory of The Survival of the Fittest.

\section{Idditional Facts About Vertebrates.}

In all the vertebrates that we have studied we have found an internal, bony skeleton. There are some animals which must be classed with the vertebrates, in which the skeleton is not bony. In such animals the skeleton is cartilaginous, and in the amphioxus, which has been called the lowest known rertebrate, the only indication of a slceleton is a cartilaginous rod along the back which is called the notochord. The no- 
tochord is the precursor of the backbone, and is found at some stage in the development of every vcrtebrate.

The amphioxus is a little animal, somewhat fishlike in form, about $2 \frac{1}{2}$ to 3 inches long, found along the Atlantic coast of the United States.

When studying the grasshopper, we found that the skeleton was chitinous and wholly extermal. In the vertebrates the skeleton is wholly internal, except, in some degree, in the turtle. The body of the grasshopper is segmented throughout, but there is no indication of such segmentation in the body of the vertebrate, except in the vertebræ of the spinal column, and it is probable that this segmentation is not at all homologous to the segmentation of the skeleton of the grasshopper.

We found reason to believe that the jaws of the grasshopper move sideways, because they are homologous to legs. No such homology can be traced between the jaws of a vertebrate and the legs of a vertebrate.

No vertebrate has more than two pairs of appendages. A centaur, with the body of a horse, and the head, shoulders, and arms of a man, is, of course, a monstrosity. But the monstrous character goes deeper than at first sight appears. An animal like the centaur would necessarily have two hearts, two sets of lungs, two diaphragms, and two sets of ribs.

It is well for us to consider the relative excellence of the breathing apparatus of the grasshopper and the rabbit. The grasshopper breathes through several spiracles along the sides of the body, and the air is carried in the air tubes throughout the body to the very place where it is to be used. Thus is obviated all necessity for blood as a carrier of oxygen. In the rabbit, the air is taken into the lungs, to which place the blood is also brought, carrying its load of $\mathrm{CO}_{2}$ and exchanging it for oxygen. The oxygen is thus 
carried by the blood to the tissues where it is to be used. It really seems as if the introduction of the blood as a carrier, or "midlleman," between the oxygen and the tissues where it is to be used is a rather clumsy contrivance.

We have seen the third eyelid, or nictitating membrane, in the pigeon and in the turtle. It is a very useful device to those animals, enabling them to see, in some degree at least, while the eye is still protected. We have seen the same organ, modified, in the eye of a rabbit. The same structure is very apparent in the eye of a dog, or in the eye of a horse, and to a less degree in the human eye. In the mammals generally, however, the structure is not at all useful. It is an organ such as is called a vestigial organ. Vertebrates generally, and mammals in particular, show many examples of vestigial organs. In the human body, that part of the intestinal cæcum which is called the vermiform appendix is not only useless, but is a positive source of danger, being subject to a disease called appendicitis, which frequently causes death.

A rabbit or a horse can move its ears. The muscle to move the ears exists in every human being, but only a very few people can move their ears. The muscle is vestigial.

The only explanation that is at all probable for vestigial organs is that sometime in the history of the species they have been useful, or, at least, functional. But in consequence of changed conditions they have lost their usefulness, and as a result, either directly or indirectly, they have lost their functions.

The farther along the path of development an animal has proceeded, and the more highly specialized it has become, the greater the number of vestigial organs we may naturally expect it to show. 


\section{CHAPTER X.}

\section{THE FRESH-WATER CLAM.}

1. Notice the two ends of the shell. In what respects do they differ?

2. The edge on which the two parts of the shell are attached to each other is the dorsal margin.

3 . On the dorsal margin, find a pair of elevations, one on each part of the shell. These are the umbones.

4. Between the umbones, and extending from them in one direction, find a smooth band, the hinge ligament. What is its use?

5. Hold the shell with the dorsal edge upward, the hinge ligament toward you. When in this position the end of the shell toward you is the posterior end, the end away from you is the anterior end, the part of the shell toward your right is the right valve, and the part of the shell toward your left is the left valve.

6. Notice the epidermis, covering the shell. The lines running concentrically around the umbo and extending over the entire shell are the lines of growth.

7. Draw a dorsal view of the shell. Draw a side view of the left valve.

\section{Interior of the Shell.}

1. Notice the color and the interior surface of the shell. Can you see the lines of growth? 
2. Notice one line near the edge, much deeper than the others. This is the pallial line.

3. Examine the hinge teeth, near the umbo on the right. Are there different kinds of teeth? Do you find corresponding teeth on the left valve? What is the use of these teeth? Draw.

4. Find a scar near the anterior end of the shell. This is the place where the anterior adductor muscle was attached. You may call it the anterior adductor impression. Find a similar scar, the posterior adductor impression, near the posterior end of the shell. Can you find another muscle scar on the shell?

5. Draw the inside of the right valve.

\section{Internal Structure.}

1. Remove the left valve carefully. Find the mantle, or pallium, which covers the entire body. Where is it thickest?

2. Find the anterior and the posterior muscles. What do these muscles do?

3. Find the siphons at the posterior end. In the salt-water clam, the siphons are permanent and are an inch or more long. In the fresh-water clam, these siphons are formed by the folding together of the posterior edge of the mantle. They are not permanent, and are manifested clearly only in the living clam. Examine the edges.

4. Carefully remove the mantle. Find the gills. How many on the left side? Study their structure. Draw.

5. In front of the gills, find the labial palpi. How many? What shape? Draw.

6. Between the palpi, find the mouth.

7. Notice the foot. Which way does it point?

8. How are the gills attached to the body? To each other? 
9. Observe two chambers inside the mantle cavity. The one containing the gills, body, foot, etc., is the branchial chamber. The other one, which is above the body, is the cloacal chamber.

10. Before taking the clam out of the shell, look for the nervous system. On the lower surface of the posterior adductor muscle, find a double yellowish body, the visceral ganglia. Find nerves leading from the pair. Draw.

11. Just behind the upper portion of the anterior adductor muscle is a small ganglion, the left cerebral ganglion. Find the short nerve connecting it with the right cerebral ganglion. Draw.

12. Just below the body in front of the foot, find two pedal ganglia. Draw.

13. In the cloacal chamber, just above the body, find the heart. The intestine passes through the heart, but has no communication with it. In the live clam, the beat of the heart is easily seen. Can you find one artery passing forward and two passing backward from the heart?

14. Trace the intestine until it opens into the cloacal siphon. Does it go above or below the adductor muscle?

15. Beginning at the mouth, trace the intestine as far as you can. Some will trace its entire course.

\section{Suggestive Questions.}

1. How does the clam get food?

2. How does the clam move?

3. How does the water get into the cloacal chamber?

4. Of what use are the siphons?

5. Does a fresh-water clam or a salt-water clam close iț shell the more closely? Why? 


\section{Additional Facts About the Clam.}

The clam belongs to a branch of animals called mollusks. The name is applied to them because of their soft body, without any skeleton. The class to which the clam belongs is called Lamellibranchiata, and this name refers to the kind of gills it has. The gill is thin, or flat, like a plate or the leaf of a book. Formerly, animals of this class were called bivalves, because of the two parts of the shell. Still another name was Acephala, which means without a head.

The fresh-water clam moves very slowly in the sand at the bottom of a pond or river. It stands on edge, half imbedded in the sand. The foot, which is very muscular, is pushed slowly out of the shell and downward and forward into the sand. After it has been pushed out into the sand until it is securely fastened, a sudden retraction of the foot itself, aided by two muscles (retractors) inside of the shell, shortens the foot. The tip of the foot being securely fastened in the sand, the body enclosed in the shell must be drawn toward it. In this way the clam, by a single impulse, may move itself one-half or one-third its length. This movement leaves a furrow in the sand, and fresh-water clams can often be discovered by following along this furrow. In the same way, when the animal chooses to do so, it can burrow down into the sand, completely concealing itself.

In order to breathe, the animal must get a current of water to flow over the gills. Since the gills are never extruded, it is necessary that the water be taken into the shell. The water enters the shell through the lower, or incurrent, siphon. In the fresh-water clam, the siphons are not permanent, but are formed merely by the lapping together of the two edges of the mantle. The edge of the lower siphon is very sensitive to 
touch, and the opening is always protected by small, finger-like or fringe-like processes which fold over the opening and protect the clam from the introduction of grains of sand and other injurious substances. The upper siphon is not so closed, but is usually quite open, and the finger-like processes diverge from the edges.

The water comes through the lower siphon into the gill chamber. Here it bathes the gills. Each gill consists of a double layer of vertical rods fastened together by transverse fibers, and the whole surface of the gill is covered by a layer of ciliated cells. The gill of the clam is one of the easiest objects in which to observe ciliary motion. It is this ciliary motion which is the principal cause of the current of water into the lower siphon.

Some of the water that enters the gill chamber passes between the vertical rods of each gill into the space between the two layers. This water goes upward between the two layers of the gill, into the cloacal chamber. The water which does not enter the gill passes forward over the palpi and in front of the mouth, and upward into the cloacal chamber, where it meets the water that has come through the gills, and with it passes backward and out through the upper, or excurrent, siphon.

In consequence of the very short siphons, the fresh-water clam usually buries itself in the sand only the length of the shell; but the salt-water clam, such as comes into our markets, has siphons which may be extended six or eight inches, thus permitting it to sink much deeper into the sand and still keep its siphons at the surface.

The food consists of very small particles of animal or vegetable matter which are carried into the gill chamber by the current that enters the incurrent siphon. It passes around in front of the mouth, 
where its presence is perceived by the palpi, and it is taken into the mouth.

The valves of the fresh-water clam seldom fit so closely to each other as do the valves of the salt-water clam. The starfish is the principal enemy of saltwater clams. It kills them by inserting its stomach, which is a very thin membrane, in to the space between the valves, and then digesting the clam within its own shell. The salt-water clam, then, must have a shell that fits very tight, or it will be killed by the starfish; but there are no starfish in fresh water, so the clam that shuts its shell tight has no advantage in that respect over the one that does not shut its shell tight.

The principal danger to the fresh-water clam is the possibility of having its valves torn apart when a strong current pounds it over the stones. The mechanical device of the interlocking teeth, near the umbo, is employed to guard against this danger. Another cause of the death of many clams is their stranding in shallow pools which afterward dry up completely. This occurs especially in river bottoms, when the water recedes after a freshet to its usual level.

The eggs of the fresh-water clam are carried for some time in the outer gill and hatched there. A gill that is carrying eggs may be known by its dark color and swollen appearance.

The shell is closed by the two adductor muscles. The shell is opened by the hinge ligament, which acts somewhat like the case-spring of a watch, opening the valves whenever the adductor muscles are relaxed. Fresh-water clams are too tough to be edible.

\section{THE OYSTER.}

Oysters in the shell can readily be secured from most markets. 
1. On the oyster shell, find lines of growth, umbo, right and left valve. Are the two valves symmetrical? Which is the larger? Which is attached?

2. Find the mantle, muscle, gills, palpi, heart, foot, stomach, and siphon.

3. State differences between the oyster and the clam.

4. State resemblances.

5. What drawings have you made?

Make a table of differences between the clam and the oyster.

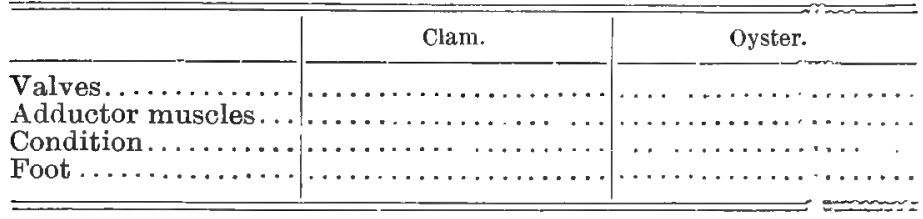

Table of Resemblances.
Clam
Oyster
\{ soft body; no skeleton four lammellate gills
no head shell of two valves valves closed by adductor muscles body enclosed by mantle which secretes shell

The oyster differs from the clam essentially in the fact that it is attached by one valve to some support. This is correlated with the facts that the foot is rudimentary, and that the shell is very rough. If the clam had as rough a shell as the oyster, it woild move through the sand with much more difficulty. This roughness of the shell, however, is of no disadvantage to the oyster. 


\section{THE SNAIL.}

1. The pointed end of the shell is the apex.

2. The large opening is the aperture.

3. The edge of the aperture is the lip.

4. Find the lines of growth, parallel to the lip.

5. Find the spiral groove, on the outside, running to the apex. This groove is called the suture.

6. Observe the turns of the shell between the grooves. These are called whorls.

7. The whorls, all taken together, excepting the largest, or body whorl, constitute the spire.

8. The axis, around which the whorls are coiled, is called the columella.

9. Hold the apex up, the aperture toward you. If the aperture is toward your right hancl, it is a dextral, or right-handed shell. If the aperture is toward your left hand, it is a sinistral shell.

10. If the snail has a lid to close the aperture, the lid is called the operculum.

11. Break off the shell and see the body. Find the foot, the head, the mantle, the tentacles, and the mouth.

12. Notice the shape of the body. You may see from the outside some of the digestive organs. The liver is the largest.

\section{'The Live Snail.}

1. WATCh LIVE SNAILS crawling over the sides of a glass jar. Can you see tentacles? Eyes?

2. See the mouth, as it opens and shuts. How does the snail eat?

3. Can you find the opening through which air is taken into the lung, or water in to the gill? collect?

4. How many kinds of snail shells can you 
Make a table of differences between the snail and the clam.

\begin{tabular}{|c|c|c|}
\hline & Clam. & Snail. \\
\hline Shell........... & $\ldots \ldots \ldots$ & $\ldots$ \\
\hline Body............. & $\mid \ldots \ldots \ldots \ldots \ldots \ldots \ldots \ldots \ldots$ & $\ldots \ldots \ldots \ldots \ldots \ldots \ldots$ \\
\hline Foot $\ldots \ldots \ldots \ldots$ & $\ldots \ldots \ldots \ldots \ldots \ldots$ & $\ldots \ldots \ldots \ldots \ldots \ldots$ \\
\hline Gills ............. & $\cdots \ldots \ldots \ldots \ldots \ldots \ldots$ & $\ldots \ldots \ldots \ldots \ldots \ldots \ldots$ \\
\hline Eyes ............. & $\ldots \ldots \ldots \ldots \ldots \ldots$ & $\ldots \ldots \ldots \ldots$ \\
\hline Head......... & $\ldots \ldots \ldots \ldots \ldots$ & $\ldots \ldots \ldots \ldots \ldots \ldots \ldots$ \\
\hline
\end{tabular}

From your table of differences, make a logical definition of a Lamellibranch.

\section{Table of Resemblances.}

Clam $\left\{\begin{array}{l}\text { soft body; no skeleton } \\ \text { usually enclosed in a calcareous shell } \\ \text { body covered with a mantle which secretes the shell }\end{array}\right.$

From your table of resemblances, make a definition of a mollusk.

\section{Additional Facts About the Snail.}

The foot of the snail, instead of being narrow and plough-like, as in the clam, is flat, and adapted for crawling over a smooth, hard surface. The mouth opens in the foot, rather forward of the center. There is an organ called the tongue, or lingual ribbon, or odontophore, which moves across the aperture of the mouth when the mouth is open.

Most of our land and fresh-water snails eat vegetable food, either algæ or decaying vegetation. This may be associated with the fact that the aperture is entire, having no notch, or prolongation. Many sea snails are carnivorous. The aperture of such a snail 
is always notched or prolonged into a spout, and the odontophore in such a case is long and narrow, and is called a radula. It is capable of drilling or sawing a hole through the shell of another mollusk.

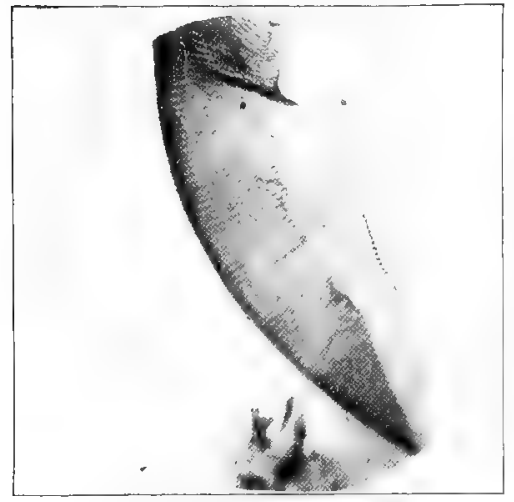

The odontophore conists of a membrane of horny material, thickly set with numerous curved teeth. It passes over the surface on which the snail is crawling and rasps off anything that the snail can eat.

(HDONTUPHUIEL "I TNAII.

Nost sea snails hreathe liy means of a gill, but the greater number of land and fresh-water snails breatle by a lung. Usuilly a snail that has an operculum, or plate to close the aperture, is a gill breather. One without an operculum is a lung breather.

Most suails have eyes, and in the case of land snails the eyes aro placed at the ends of eyo stalks. In the greater number of our pond snails, however, the eyes are not on stalks, but are situated at the base of tentacles.

Some snails, called slugs, are without any shell, or have only a rulimentary shell which is concealed beneath the epidermis.

Snails belong to a class called casteropords. The name in given becaume the snail looks als if it were crawling on its belly. Thry are also called univalyes, because the shell is in one piece. 


\section{THE EARTHWORIM.}

1. Can you distinguish a head and a tail?

2. Has it a dorsal and a ventral surface?

3. Has it a right and a left side?

4. How many segments, or somites, can you count? Are they all alike?

5. Observe the cingulum, or girdle, near the anterior part of the body. How many segments does it cover? How many segments in front of it?

6. If your earthworm is alive, watch it crawl. Describe the action fully. Can it crawl backward?

7. If your earthworm is alive, see the blood in the dorsal blood vessel. Is there a corresponding ventral blood vessel?

8. Examine the first segment of the body. Note the rounded lip in front, the prostomium.

9. Find the mouth.

10. Feel and see, on the ventral surface, little bristle-like organs, the setæ. How many on each segment? Of what use can they be?

11. Find a delicate outer membrane covering the body-the cuticle.

\section{Internal Structure.}

1. Pin the body, back upward, under the water, on weighted cork. Carefully cut through the body wall from the tail to the head. Pin out the sides of the cut.

2. Find the septa, which divide the body cavity in to chambers. How many?

3. Can you find the dorsal blood vessel? What branches does it give off?

4. Trace the alimentary canal. Distinguish the following parts: the buccal sac, in the first three segments; the thick-walled portion, in segments 4-7; the cesophagus, in segments $8-12$; the crop, in seg- 
ments 13-16; the gizsard, in segnenti 17-20; the intestine, the rest of the way.

5. In the Hoor of the hody cavity, note the nerve cord and ganglia.

\section{Cross Seretion.}

1. The cuticle has already been seen. The cross section shows the vuter layer" of muscles. This layer

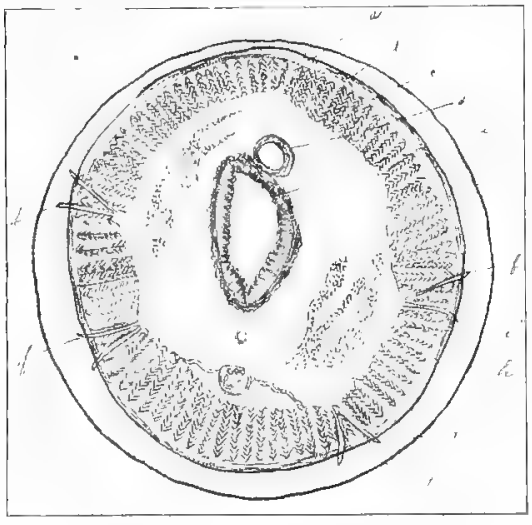

CROSS SECTION OF EARTHWORM.

$a$, cuticle: $b$. circular muscle: $c$, lon. gitudinal muscle; $d$, lorsal blowlvessel ; $e$, alimentary canal; $f$, setie; $s$, ventral nerve cord; $h$, ventral blood ressel; $i$, reproductive organs. is circular, and runs around the body. When it contracts, it tends to diminish the diameter of the body; but by the diminution in diameter, the length becomes greater, and the distance between the head and tail is increased. If the setæ point backward, as they ordinarily do, the increase in distance between the head and tail will drive the setre at the postexior part of the hody into the ground, and so funish an anchor which prevents the tail from moving lackward; hence, longthening the hody pushes the hoad forwand. When the hoar is pushed forward, the backward printing sotac slip freely ov'r the surface. Thus there is a forward movement of the hoad, and no hatckward movement of the tail.

2. The crosis section shows also a layer of musches inside the circular latyer. "This is a layer of longitudinal 
muscles. Suppose the body is extended, as described in the preceding paragraph. Now the longitudinal muscles contract. The tendency is to shorten the distance between the head and the tail. The head tends to be drawn backward, but by this movement the backward pointing setæ that are near the head are driven into the ground, while those at the posterior of the body move freely over the surface; hence the tail is drawn forward. The result of these muscular contractions, alternately performed, is to send the body forward. If the setæ, however, are directed forward, as they may be, the result of the same contraction is to send the body backward.

3. The cross section shows the intestine, the dorsal blood ressel, and the ventral blood vessel; also, the ventral nerve cord, lying below the ventral blood vessel, with nerves extending to the muscles of the body wall. The nerve cord seems to be composed of three cords, or elements.

4. The cross section shows eight setæ, arranged in four pairs. Each pair has a muscle by means of which it may be retracted or thrust out, and directed forward or backward.

5. One group of reproductive organs is seen. Both male and female reproductive organs are found in every earthworm. The male reproductive organs occur in some worms in segments 9,10 , and 11 ; the female organs (ovaries), in segments 13 and 14 . The position of these organs varies somewhat with the different kinds of worms. More than 35 different kinds of earthworms occur in the United States.

The earthworm is hermaphroditic, although (as in the case of red clover and of many other flowers) cross fertilization is necessary. That is, the male principle of one worm fertilizes the female principle, or egg, of another worm. The eggs of the earthworm are laid in capsules, each capsule containing six to eight eggs. 


\section{Additional Facts About the Earthworm.}

We find in the earthworm no lungs, gills, or other breathing organs. It is very evident that the worm must breathe; that is, there must be an exchange of $\mathrm{CO}_{2}$ for oxygen. This exchange of gases takes place directly through the skin. The skin is a thin membrane which is kept moist by the conditions in which the animal lives. It is in effect a thin, moist membrane, with blood loaded with $\mathrm{CO}_{2}$ on one side, and with oxygen on the other. These are the only conditions necessary in a breathing organ, and are the conditions attained in the construction of lungs and gills.

This fact enables us to account for some of the habits of earthworms. Earthworms seldom come out of their burrows in the daytime, except when it is raining. At such a time, they often appear in great numbers and in unexpected places. Some people believe that they rain down. They neither rain down nor are drowned out. The rain and moist atmosphere enables them to move freely on the surface of the ground without danger of suffocation. Often, at the close of the shower, worms are stranded on pavements or other places into which they cannot burrow, and so perish.

Should earthworms come out of their burrows in daytime when the air is dry, the skin would quickly become dry and they would be in danger of perishing. At night, the danger from this source is much less, and this sufficiently accounts for their activity at night and apparent quiescence in daytime. Although they have no eyes, Mr. Darwin found reason to believe that they could tell the difference between daylight and dark, by means of the first two segments.

We take the earthworm to represcnt the branch of Vermes. It is probably as good a representative as we 
can have, although no one worm can adequately represent the whole branch. In fact, it would perhaps be better to break up the branch of Vermes into several branches, because of the great difference between members of the group. It seems as if the men who defined the limits of the branches of the animal kingdom had picked out the animals that clearly belonged to other groups, and then said, "We'll call all the rest of the animals worms." There are commonly reckoned about ten classes of worms, all very different from each other.

Some worms are round, as the earthworm is, and some are flat, like the leech. Some have suckers at one end or at both ends. Some have the mouth at one end of the body, and some have it in the middle. Some have septa between the segments, and some have no septa. Some lay eggs, and some are viviparous; that is, the young are born alive. This is true of the vinegar worm, and of the trichina, a parasite which infests pork. Some worms (Brachiopods), have a shell, like a clam shell, and others have no shell. In fact, mollusks themselves may be considered as only a highly specialized group of worms. It is almost impossible, from a study of a sufficiently varied number of specimens, to make a table of resem. blances from which to derive a definition of worms which will discriminate this branch from all other branches.

Most of the worms are aquatic, and the greater number live in the sea. This fact we would expect to be true from their lack of breathing organs and consequent necessity of keeping the body moist. Many worms are parasitic, as the trichina, already mentioned, and the tapeworm. The Gordius, or hair worm, which is quite common, is parasitic in one stage of its existence. The very common belief that the hair worm is a transformed horse hair, is not only unfounded, but fails to recognize that a Gordius has various complex and 
complicated organs and life processes that it is impossible to think of in connection with the structure of a hair. It would take a long while for a hair to get a stomach, a nervous system, and reproductive organs.

Make a table of differences between the earthworm and the caterpillar.

\begin{tabular}{|c|c|c|}
\hline & Caterpillar. & Earthworm. \\
\hline $\begin{array}{l}\text { Breathing organs........ } \\
\text { Jaws........................... } \\
\text { Feet......................... } \\
\text { Eyes........................ } \\
\text { Antennæ................. } \\
\text { Reploduction............ }\end{array}$ & 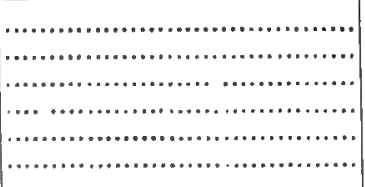 & 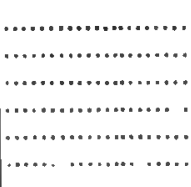 \\
\hline
\end{tabular}

We see from this table that it is very incorrect to speak of a caterpillar as a worm.

\section{THE STARFISH.}

The branch to which the starfish belongs has no representative on the land or in fresh waters. If it is to be studied, specimens must be procured from the seashore.

1. Find the arms. Find the disk, which is the part of the body from which the arms radiate. Find, on the upper surface, the madreporic body, which is small and white or red. Notice also the spines. Look closely around the base of the spines for the pedicellaria. Draw the upper surface.

2. On the lower surface, look for the mouth in the center. Are the spines around the mouth just like the other spines?

3. In the middle of each arm, find the ambulacral furrow, or groove. Find in this groove the ambulacral suckers, or tube feet. How many? How arranged? 
4. Find the radiating nerve in each arm, between the rows of tube feet. Trace it from the circum-oral nerve ring around the mouth, to the eye-spot at the tip of the ray, or arm.

5. The lower surface is called the oral surface. The upper surface is the aboral surface. Draw the oral surface.

6. Remove carefully the aboral surface. Find on the inner surface of the part removed, in each ray, a thin band, the extensor muscle. What is its use?

7. Find the hepatic cæca, which are the large, brown, lobulated organs in each ray. The membrane which holds them in place is the mesentery. Are the hepatic cæca connected with the stomach?

8. Note the stomach, in the center of the disk. How is it connected with the aboral surface? Find the retractor muscles, which draw the stomach back into each ray.

9. Find the reproductive organs, which are along the angle of each ray. There is little difference in appearance between the organs of the male and the female starfish.

10. Find the stone canal, which extends from the madreporic body to the circum-oral water ring. From the circum-oral water ring, trace the radial water tube into each arm.

11. The radial water tubes carry water into the ampullæ, or little sacs, which lie in the floor of each ray. What is the relation between the ampullæ and the tube feet? Are the ampullæ that are near the mouth like the other ampullæ?

12. Examine the plates which constitute the framework.

\section{Facts About the Starfish.}

The starfish represents the branch of Echinoderms. It is named from a thick skin which is beset with 
spines. The name means hedgehog-skinned. In the sea urchin, the spines are longer and the appropriateness of the name is more clearly manifested.

We meet an entirely new fact in the study of the starfish. There is neither head nor tail, nor is there a right and a left side. We could divide it into five parts, each part containing one arm, and the parts would be approximately equivalent to each other; but the parts, or arthromeres, are not arranged serially, one behind another, as are the segments in a grasshopper or an earthworm, but they radiate from a common center. From this fact, animals of this branch were formerly called Radiates.

An animal that has a right and a left side which are approximately equal to each other, is said to be bilaterally symmetrical. Bilateral symmetry is the correspondence between the right and left sides. All the animals that we have previously studied have been bilaterally symmetrical, except the oyster and the snail. In these instances the symmetry is obscured.

The starfish is not bilaterally symmetrical, although it is possible to draw a line through the madreporic body that shall divide it into two corresponding parts. The bilateral symmetry is subordinate to the radial arrangement.

The stomach of the starfish is quite voluminous, and is capable of being thrust out of the mouth and wrapped around an object which it wishes to digest. It is very thin, and can be insinuated into a very small crack between the valves of a clam or mussel or oyster, and these are the animals which constitute the principal prey of a starfish. The intestine is very short, and while it is possible to demonstrate that it has an external opening on the aboral surface, such opening is not readily apparent.

We are introduced in the starfish to an entirely new method of locomotion. It is a hydraulic, or 
water-pipe system, by means of tube feet. The whole water-pipe system is filled with water which enters through the madreporic body, passes through the stone canal, through the circum-oral water ring, through the radial water tube into the ampullæ. Here the contraction of little muscles forces the water into the tube feet, extending them to their full length. When the tip of one of the tube feet is pressed against a flat surface, the lifting of the central portion of the disk at the tip creates a vacuum which fastens that foot to the surface. As the tube foot then shortens, the ray to which it belongs is drawn closer to the point of attachment. By the action of many tube feet, the starfish progresses, although it moves exceedingly slow.

The starfish has the power to reproduce lost parts in a very marked degree. If all of the rays except one be pulled off, the starfish will still live, and it will soon reproduce the missing rays.

There are no specialized breathing organs. The water-pipe system performs the function of respiration.

The pedicellariæ are small, pincer-like organs surrounding some of the spines on the aboral surface. Their function is not fully known.

Review of Clam, Snail, Earthworm, and Starfish.

$$
\text { The Clam. }
$$

1. What are the valves?

2. How distinguish the right and the left valve?

3. What is the umbo?

4. What is the hinge ligament?

5. What is the mantle?

6. What are the palpi?

7. How many gills has the clam? Explain their structure. 
8. What are the siphons?

9. What are the adductor muscles?

10. What closes the shell?

11. What opens the shell?

12. How does the clam get food?

13. Where is the heart?

14. What and where is the cloacal chamber?

15. What causes the current to go over the gills?

16. How does a clam move?

\section{The Srail.}

17. Define these parts of a snail: spire, whorl, apex, aperture.

18. Distinguish between right- and left-handed shells.

19. What is the odontophore?

20. How does a snail crawl?

21. How distinguish a lung-breathing snail from a gill-breathing one?

22. How distinguish a flesh-eating snail from a vegetable-eating one?

\section{The Earthworm.}

23. How does an earthworm breathe?

24. How does an earthworm crawl? What muscles does it use?

25. What are the setæ? What is their use?

26. What are the reproductive organs?

27. Why does the earthworm come out of the ground during a rain?

28. What is the cingulum?

\section{The Starfish.}

29. How many arms has a starfish?

30. What is the madreporic body? The stone canal? What are the tube feet?

31. Describe the water vascular system in full. 
32. Describe the nervous system.

33. Describe the stomach.

34. How does a starfish more?

\section{FRESH-IVATER HEDRA.}

Fresh-water hydras may be found in almost any pond, and almost any time in the summer. They are too small to be studied satisfactorily without a microscope, but can readily be seen with a hand lens, or with the unaided eye.

1. Observe the size and the sliape of the body.

2. Notice how the body is fastened to the support on which it rests. This end of the body is the foot.

3. Observe the tentacles. How many? How arranged? Are they smooth or warty? The mouth is in the center between the tentacles.

4. The rounded prominence upon which the mouth is situated is the hypostome.

5. Perhaps a bud may be seen growing from the side of the hydra.

The hydra is the only fresh-water representative of a large branch of animals.

The branch is called Cœlenterata, and includes the Hydroids, Jelly fishes, Corals, and many other forms. It has no respiratory apparatus, no nervous system, no heart or blood, no stomach or digestive ap-

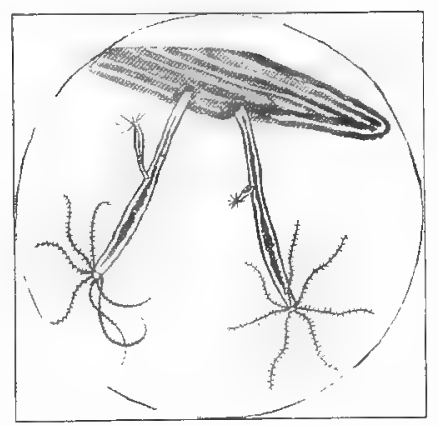

FRESH-WATER HTDRA. paratus. It has a permanent body carity, into which food is taken, and in which it is digested, but the hody wall itself acts as the stomach. There is no separate stomach or intestine. 
The hydra has a special provision for capturing small animals which constitute its food. Certain cells in the tentacles are provided with a coiled, springlike thread terminating in a harpoon point. When a small animal like Cypris or Daphnia comes near the tentacles, the little harpoons dart out from the nematocysts, or lasso cells, and stick into its body. This paralyzes the animal, which is then drawn by the tentacle to the mouth.

The hydra is a notable example of the ability to reproduce lost parts. It may be cut into two pieces, and each piece will become a hydra. It may be turned wrong side out, and what was before the external surface will take on the function of digestion. If all the tentacles are cut off, new ones will grow out.

Hydras reproduce by budding, and by eggs. In the case of budding, a small bud grows out on one side of the body, which gradually develops tentacles, a mouth, and a body cavity. Finally it separates from the parent and attaches itself to another support.

Hydroids are very abundantin shallow water along the sea shore. They look like plants, branching freely, and each branch being tipped with a flowerlike body, somewhat similar to the hydra. All the hydranths, or hydra-like bodies, that grow from a common stem constitute a colony of individuals which are dependent upon each other. What one eats, nourishes all. In a case like this, what shall we call the individual? Is it the single hydranth, or is it all the hydranths that grow from a common stem? The budding of the hydra manifests the same thing. If the young hydra did not separate from the parent, should we have one individual or two? It is not always easy to tell what constitutes an individual.

Hydroids manifest the phenomenon of alternation of generations. Some hydroids give rise to jelly fishes, and the eggs laid by some jelly fishes produce hydroids. 


\section{FRESH-WATER SPONGE.}

Fresh-water sponges may be found in clear water in most parts of the United States. They grow attached to submerged logs, stones, or stems of bushes. One of the most common forms is Myenia fluviatilis.

1. Observe the sponge mass as a whole. Notice its lack of definite shape.

2. See the large openings in the surface of the sponge. These are the oscula, or excurrent pores. The currents of water come out of these pores.

3 . See the clusters of spicules around the oscula. Observe also the pointed spicules projecting above the surface.

4. Cut through the sponge and look at a cross section. Is there more than one layer of sponge substance? Does the sponge grow year after year?

5. Look in the substance of the sponge for little seedlike bodies. These are gemmules, or reproductive bodies.

6. Where are the gemmules? Do they form a layer at the base? Are they scattered through the substance of the sponge?

7. Examine the sponge as well as you can for the spicules.

8. Observe the color of the sponge. Is it green? Did it grow in the sunlight?

9. Spicules of a sponge may be separated from the sponge substance by boiling first in sulphuric acid, then adding, cautiously, nitric acid. The acid may be removed by adding much water and allowing it to settle, and repeating this process until all the acid has been washed away.

Commercial sponges consist of the skeletons of certain kinds of marine sponges. The fibers of these skeletons are composed of a substance called spongiolin, which is very much like chitin. Spongiolin is found also in fresh-water sponges, but it is small in 
amount and only sufficient to hold together thespicules, which are very numerous.

There are three kinds of spicules in a fresh-water sponge: skeleton spicules, domal spicules, and gemmule spicules.

\section{Microscopic Objects.}

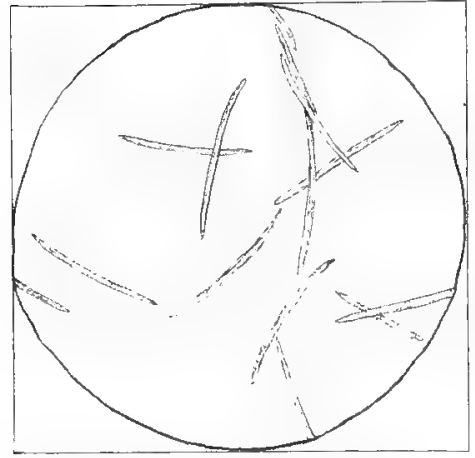

The skeleton spicules are the largest and are arranged in filaments which constitute the skeleton. A cross section of one of these skeleton filaments will show the cut-off ends of three or four spicules, with a cententing material of spongiolin. In some iustances, at least, these spicules are hollow.

SPICELES OF FRESH-WATER SPUNGH

Usually, the skeleton micules are slishtly curred, and more or loss covered with spinous processes. They are arranged in filaments of three or four spicules lying side by sicle and with thrix ends orerlapping the ends of succeeding spicules, all held together by spongiolin. The filaments extend from the base of the sponge to the surface.

The skmeton filanenti fumish the support for the cells which comstitute the boxy of the sponge. These colls are allanged so that each one constitutes a part of the wall of a small chamber which communicates with ono of the canals whose external openings are the excurrent pores.

Tho contion sponge is covered with an epilermis, in which are timbediled dermal spicules, usually smaller than the skeleton spicules. 
The water goes through numerous small holes in the epidermis, into a subepidermal chamber. It then filters throughout the sponge, hathing every cell, and finally passing out through the excurrent canals. It is caused to move in the sponge by cilia, one of which is found in every sponge cell that lines one of the canals. By this movement of the water, food and oxygen are brought to each cell.

The gemmule consists of a mass of granular protoplasm surrounded by a thick wall in which are embedded many spicules arranged radially. These gemmule spicules are often somewhat spool shaped, or like an axle with a wheel at each end. There is always an opening from the inside of the gemmule through the wall.

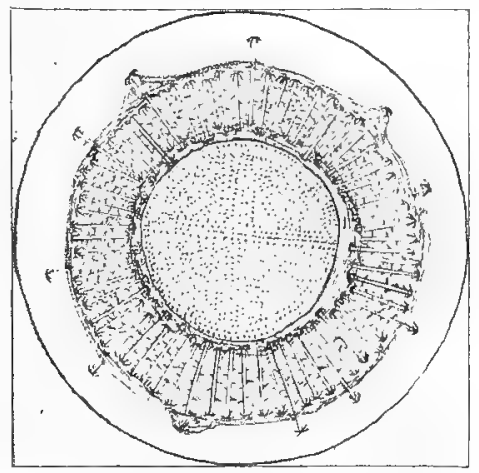

CROSS SECTION OF GEMMULE OF FRESHWATER SPUNGE

(HETEROMYENIA ARGYKOSPERMA).

The spicules are siliceous; that is, they are composed of about the same material that glass is male of. Consequently, acicls do not affect them. Most marine sponges have calcareous spicules, hut in all fresh-water sponges the spicules are siliceous.

\section{Arditional Facts About the Sponge.}

The fresh-water sponge has no definite shape. Its shape is determined by its rapidity of growth in any given direction. It has no mouth, no body carity, no stomach. It can searcely be called an individual, but is a mere aggregation of cells. Each cell freathes for itself, takes its own food, and does just what every other cell does. 
The sponge is usually colored more or less green. The color is due to the presence of the same coloring matter that is found in leaves. It is chlorophyl, and uses up carbon dioxide, setting free the oxygen. It is probable, however, that the chlorophyl is not a part of the sponge itself, but is due to some vegetable organism that finds a lodgment among the sponge cells.

All fresh-water sponges die in the winter and nearly all disintegrate. Myenia fluviatilis, however, is firm enough to withstand disintegration, and in the spring the old sponge furnishes a substratum for a new growth from gemmules.

\section{PROTOZOA.}

One of the characteristics of the Protozoa is that they are too small to be studied without a microscope. However, some of them are large enough to be recognized by the unaided eye or by the use of the simple lens.

The bell animalcule is exceedingly common in ponds and ditches. The body is bell shaped and is attached by a slender stalk to some support. The rim of the bell is surrounded by a fringe of cilia which by their vibration produce currents of water that bring particles of food to the mouth.

The cilia are borne on a ridge which constitutes the rim of the bell. This ridge is called a peristome. The mouth is within the peristome, but at one side.

When a number of food particles have been accumulated by the vibration of the cilia, the bell and the stalk are suddenly and strongly contracted. The stalk is very much shortened by being thrown into five or six spiral coils. The cilia fold inward, the 
rim of the bell is drawn quickly together, the bell becomes almost spherical, and by this action the food is forced dowllward into the mouth. There is no stomach or hollow body cavity. The food is merely crowded into the body mass, as a stone can be crowded into a lump of dough.

\section{Microscopic Objects.}

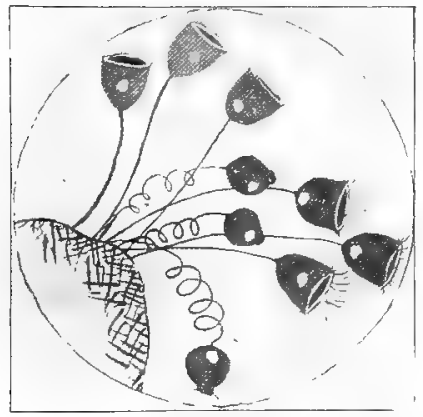

VORTICELLA.

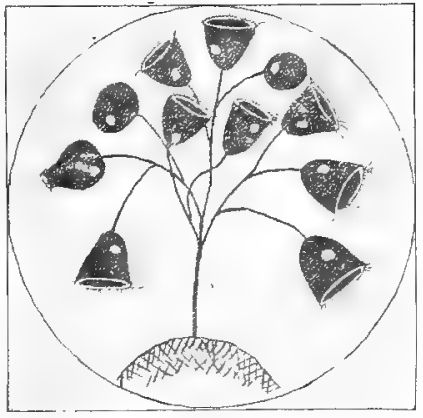

CARCHESIUM.

Vorticella proper has only one bell on one stalk. The stalk does not branch.

In Carchesium, the stalk branches and each branch bears a bell at its extremity, the whole colony looking like a tree with a flower bell at the tip of each twig. The bell and the stalk are both contractile.

In Epistylis, the stalk branches as in Carchesium. The bell, however, is somewhat more elongated, and the stalk is not contractile.

Usually, in the body of the bell, several food. masses may be found which are readily distinguishable by their color, and a clear, transparent body may be seen which, at intervals of half a minute or more, gradually contracts and disappears and soon reappears. This is called the contractile vesicle. 


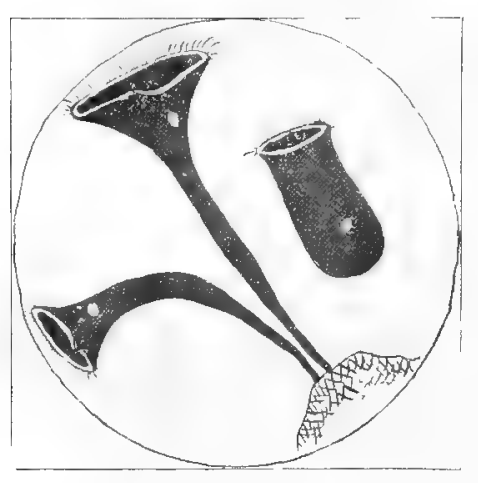

STENTOK.

The Stentor is called the Trumpet animalcule, and is somewhat larger than the vorticella. It is frequently seen in large numbers. In all essential respects it is much like the vorticella, having the ciliated peristome, food balls, and contractile vesicle, and ingesting food in the same way. It has no stalk, but, while feeding, attaches itself to some support by means of the small end of the bell, or trumpet. When so attached, the borly elongates, thus giving the trumpet appearance, and the wide end of the trumpet can loe turned in any direction. When not attached to a support, the body is $T$-whaped in section, and swims about freely by means of cilia which cover the surface of the body.

These cilia are much smaller than those upon the peristome.

The Paramucium may be found in water that has become foul by the decay of animal or vegetable material.

A jar of water in which a clam has been left to die is sure to be a very prolific source of Paramoecia.

From its shape, the

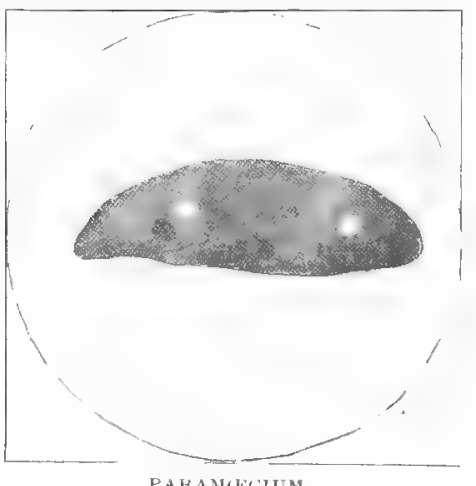

PAHAMIIITM.

Paramectum is called the slipper animalcule. It is ciliated all over its body, and swims about fieely. 
It has a mouth, which is situated at the extrenity of a groore running somewhat spirally from one end of the body about two-fifths of the way to the other end. The food balls and contractile vesicles described under vorticella are seen here.

The paramøcium, stentor, and vorticella are among the largest and most complex of the Protozoa. The Amcha is one of the simplest. It is frequently found crawling in the ooze at the bottom of a pond, or in mud that has been taken from a pond. It

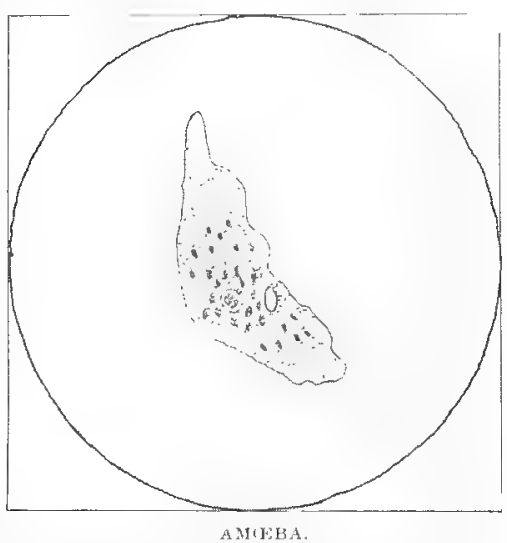
is a mass of naked protoplasm, which serems to flow along the surface of the glass slide on which it is placed for observation.

A small stream of protoplasm will fow out in one direction and the rest of the borly will apparently flow in the sane direction and join the stream; other streams, that had previously started to flow out, will flow back and join the body, and all will flow in the one direction until the body has moved its position.

If a particle of food is found in the way, the body merely flows around it, enveloping it, and if part of the substance that has been enveloped is found to be indigestible, the body flows away from it and leaves it.

There is no hearl, nutail, no definite shape, no cilia, no mouth. Food particles are usually seen enclosed in the body, and a nucleus appears in most anuebex. 
A table of resemblances among the vorticella, stentor, paramœcium, and amœba will show the following :-

$\begin{array}{ll}\text { Vorticella } & \text { Stentor } \\ \text { Paramoecium } & \text { each consists of a single animal cell } \\ \text { Amomposed of protoplasm } \\ \text { ingest food in solid particles } \\ \text { exchange } \mathrm{CO}_{2} \text { for oxygen } \\ \text { aquatic } \\ \text { each has a nucleus } \\ \text { are very small } \\ \text { exhibit self activity } \\ \text { multiply by fission }\end{array}$

This gives us a concept of a Protozoan. A Protozoan is an animal that consists of a single animal cell, is composed of protoplasm, etc.

The Protozoa constitute a very large and important branch of animals. In number of individuals at any one time, they probably exceed all other animals taken together. In degree of complexity, there is perhaps as much difference between the simplest Protozoan and the most complex Protozoan as there is between the simplest and the most complex animals of any other branch.

It is very interesting to observe the change that has taken place in the ideas of men concerning animals. The first division of the animal kingdom was into two groups, the Vertebrates and the Invertebrates. But it was early discovered that among the Invertebrates were several groups entitled to equal rank with the Vertelorates, so a division into four groups was recognized: Vertebrates, Articulates, Radiates, and Mollusks. Still further study showed that Articulates should be separated into Arthropods and Vermes. Then the sponges were recognized as animals, and the Protozoa were discovered; also, the Cœlenterata were separated from the Radiates. 
The Protozoa multiply by fission; that is, by division beginning at the nucleus. The body separates into two parts which are approximately equal in size and appearance. In this case, which is parent and which is child? Which is the older and which is the younger? Are both the offspring, or are both the parents? If one is as old as the other, both must be as old as the first one, because the first one has not died. There is no dead body. It is possible to carry this process on in thought for a thousand generations without a single protozoan having died a natural death. In fact, there seems to be no provision for natural death among the Protozoa. Practical immortality is a characteristic of Protozoa. Of course, it is understood that Protozoa may be killed. They may be eaten by other animals, may dry up, they may be killed in a thousand ways, but in every case this is an unpremeditated and unnatural end. Protozoa do not lay eggs. An egg is a single animal cell, but a protozoan itself is a single animal cell. If the protozoan were to produce an egg, it would be merely dividing itself into two cells. That is what occurs, but the two cells are alike, and one is no more an egg than the other. Neither one is an egg unless it is capable of developing into a more complex structure. But an egg would not need to undergo development to become a one-celled animal.

A protozoan, such as a paramœcium, moves, but it has no muscles. It breathes, that is, exchanges $\mathrm{CO}_{2}$ for oxygen, but it has no lungs or breathing organs of any kind. It digests, but it has no digestive organs. It seems to feel, but it has no nervous system. It has no skeleton, and of course it has no heart or blood, for it is so small that no carrier is needed to convey material, such as the blood carries, from one part of the body to the other.

The explanation seems to be this, and this will fur- 
nish an explanation also for the cells that constitute the different organs of our own bodies. The single cell of the paramcecium is capable of performing all the above named functions. When it contracts, it is exercising the function of a muscle cell, and it is a muscle cell. When it digests, it is a digestive cell. When it respires, it is a respiratory cell. The muscle cell of the human body may be thought of as a cell, like the protozoan cell, whose contractility has been very much intensified and all other properties very much diminished or held in abeyance or entirely lost. So with a nervous cell. Its nervous character has been very much -intensified and its contractility and other properties entirely lost. The protozoan cell is, as a cell, quite undifferentiated in its functions.

Make a table showing resemblances between paramocium, sponge, hydra, starfish, earthworm, clam, grasshopper, and rabbit.

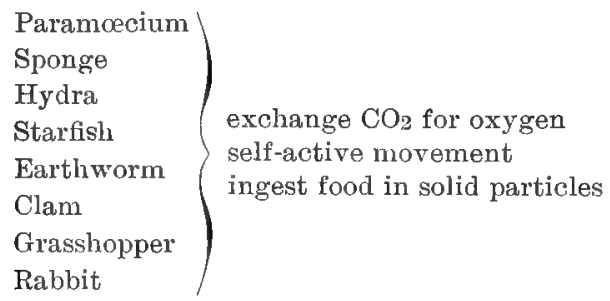

From the above table, make a definition of an animal. What is your predicate noun?

We are not able at this point to make a table of differences between animals and plants. It is very doubtful whether the above characteristics would completely discriminate an animal from a vegetable. But this is the best that we can do until we study plants. Let us call these characteristics animal characteristics. 
PROTOZOA.

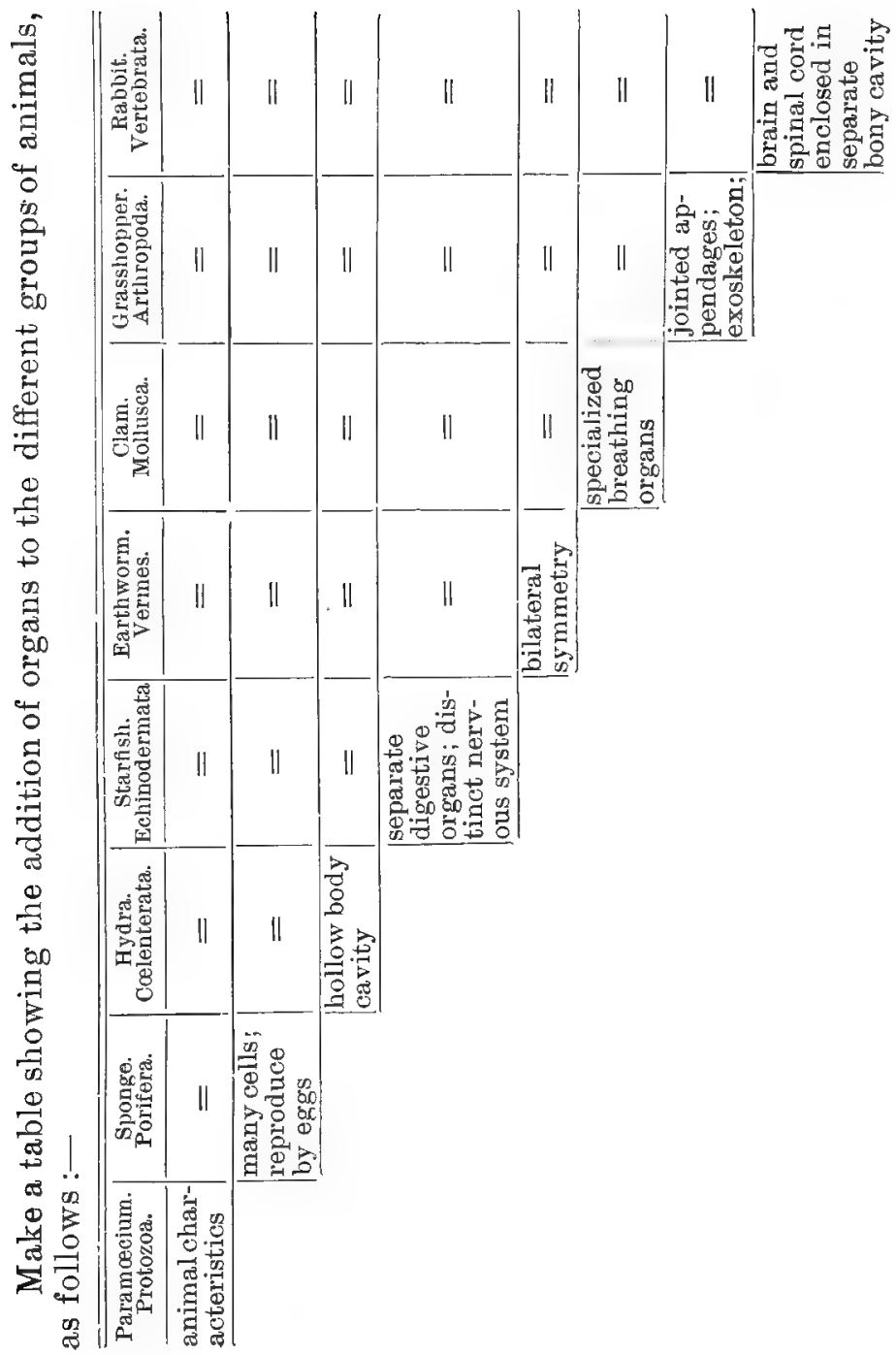


An examination of the foregoing table shows us what is meant by a more complex structure. In general, each animal named in the table possesses the positive characteristics of the several animals preceding it and some special peculiarities of its own.

We are ready also from a study of this table to make a logical definition of each branch; e.g., an Arthropod is an animal that is composed of many cells, has a hollow body cavity and separate digestive system, is bilaterally symmetrical, has specialized breathing organs, jointed appendages, and an exoskeleton.

Compare this definition with the one derived from the table of resemblances on page 77 . Have we learned anything about the grasshopper since we ceased studying it?

\section{GENERAL REVIEW TOPICS.}

1. Define Ontogenetic series.

2. Define Phylogenetic scries.

3. Define Taxonomic series.

4. What is a notochord?

5. What is meant by homologous organs?

6 . What is meant by bilateral symmetry?

7. What is radial symmetry?

8. What is a parasite?

9. How many methods of breathing have you found?

10. What is the essential process in breathing?

11. What is the essential organ in breathing?

12. How many methods of locomotion have you found?

13. What is meant by protective resemblance?

14. What is meant by mimicry?

15. What are warning colors?

16. What classes of animals have no nervous system?

17. What are vestigial organs? Give examples.

18. What methods of escape from their enemies do an imals employ? 
19. What different kinds of covering have animals?

20. What is meant by metamorphosis?

21. What are the principal groups in classification?

22. What is von Baer's Principle?

23. What is meant by Natural Selection?

24. What is meant by The Survival of the Fittest?

25. What animals are useful to man?

26. What animals are injurious to man?

27. State the rules for naming animals.

28. What methods of reproduction have you found?

29. What is parthenogenesis? What is hermaphroditism? 


\section{CHAPTER XI.}

\section{COLLECTING AND PRESERVING MATERLAL,}

WITH SUGGLSTIONS UPON ITS MANAGEMENT IN

THE CLASS.

The following chapter is designed to aid teachers and pupils in collecting and preserving material for class use. It is given as the. result of ten years' experience with large classes, during which many devices have been tried and many failures recorded. Erery device suggested here has been successfully employed.

Grasshoppers.-About five grasshoppers will be needed for each pupil in the class. These are best collected in the early fall. The large Melanoplus differentialis is easily collected in some places. An insect net will usually be needed to collect them. The grasshoppers should be killed by dropping them immediately into a bottle of alcohol. They should afterwards be transferred to such jars as Mason fruit jars and kept in strong, clear alcohol.

CRICKETS.-One for each pupil in the class will be sufficient. They should be searched for by turning over boards, stones, logs, and bunches of grass. They can be captured by hand or by a net. They should be preserved in alcohol, in the same manner as grasshoppers.

KaTYdids. - Sometimes they can be obtained around electric lights. Usually they can be captured on low bushes, such as willows, or in the meadow grass. In general, all insects are most satisfactorily preserved in strong alcohol. 
WaLking sticks can be found in most places in the United States on low bushes. Sometimes they will be found very abundantly over a limited area, as on a single tree or a small number of trees. No net is needed for their capture.

Butterflies are usually plentiful over flowers or in a clover field. Occasionally the Anosia are in very great numbers for two or three days at a time. They should be killed in a cyanide bottle, or by pouring a few drops of chloroform or gasoline along the sides of the abdomen. They should be preserved dry. A piece of paper about five inches square is folded cornerwise, one of the edges turned over, and the butterfly dropped in. A fold of the other edge closes the triangle. Forty-eight hours before the butterflies are needed for use the paper triangles containing them are sprinkled heavily with water and placed in a tin box with an air tight cover. The dried tissues will then relax and the butterflies will be as useful as if freshly caught. It will be found necessary to raise caterpillars to obtain chrysalids, although in some places cocoons of such moths as Cecropia may be cut from the trees. Caterpillars are also to be preserved in strong alcohol.

Beetles may be found by turning orer logs and stones. Some kinds, such as Harpalus, are frequently found in great numbers under electric lights. Grubs must be searched for by digging up the ground. In early spring the grubs are frequently numerous in meadows.

SQUASH BUGS can usually be found wherever squash vines grow. In August or September is the best time to look for them.

Giant Water BUGS are most easily collected from under electric lights. They may be drawn from shallow ponds with a minnow seine, and a very similar bug, though smaller, Zaitha fluminea, is found abundantly in similar places. 
DRAGON FLIES of the larger kind are hard to capture in quantities. Sinaller species of Agrion may be used instead of the larger Libellulidæ. The larvæ may be dragged from a pond with a minnow seine or a dip net.

It is very advantageous to have a wire net for dipping specimens from the water. A hemispherical fly screen, such as is sometimes used for covering table dishes is very convenient for this purpose, when soldered to the wire hoop of an insect net.

Bumblebees are easily captured in a clover field. They are most abundant in early fall. They are most easily captured in an insect net, although on a cool morning a net is superfluous.

Every farm boy knows how to jug bumblebees. When a nest is found, a jug containing a small quantity of water is unstopped and set near the opening of the nest. The nest is then stirred up lively with a pole, and the operator retires with celerity to a safe distance. The bumblebees that come out of the nest, finding no on $\theta$ to attack, will begin to settle down, but instead of returning to the nest, most of them will go by pairs into the jug.

Hornets may be captured by closing the aperture of the nest and injecting chloroform until all commotion ceases.

Mud nests should be procured whenever they are finished. If necessary, wasps may be collected from the flowers.

House flres may be most easily secured from a wire trap.

Spiders may be captured with the hands. There is no danger from a spider bite, and spiders very seldom bite. The brilliant Argiope riparia is frequently found in great numbers along hedges or on low bushes where cattle and other stock are not allowed to run. 
Centipedes may be found by turning over flat stones or logs, or pulling loose the bark from dead and decaying stumps and trees.

CRAWFish may be captured with a minnow seine, or caught with bait. A piece of liver as large as a man's fist is tied to a string and thrown into the stream. Crawfish cluster over it and cling to it, even when drawn above the water. A net or dredge gently slipped under the combination of liver and crawfish will prevent the escape of many. Crawfish should be boiled before being put into strong alcohol.

Sow BUGS are to be looked for under boards or other articles that lie on the ground. They are found only in damp places.

TADPOLES are collected from ponds in early spring. It is well to collect a supply of toad eggs, frog eggs, young tadpoles that show the gills, larger tadpoles for dissection, and tadpoles that show the legs in various stages of development. If some frog eggs or toad eggs are discovered that are freshly laid, or better, if a female is confined in a jar at the time when the eggs are deposited, the different stages in the egg development may be obtained. Two-celled, four-celled, eightcelled, sixteen-celled, and thirty-two-celled stages are all easily recognized with a simple lens.

Toad eggs and all other soft material are best preserved in formalin. This can be obtained from drug stores for about sixty cents a pound. Four per cent of formalin has been found a very satisfactory strength for laboratory use. Dilute one pound of formalin with about twenty-four pounds of water. Put it into fruit jars and drop frog eggs, tadpoles, and such material in to it. This makes an effective preservative for less than twenty-five cents a gallon.

Frogs and toads are preserved also in formalin.

Fist may be captured in the fishing season and preserved in the same way, but if the school is near a 
market, it will be found better to purchase them fresh when they are needed.

For the proper preservation of vertebrate material while it is being studied, two plans may be used. Usually it will be found advantageous to study vertebrates in the winter, that being the most convenient time for procuring and preserving the material. A large ice box will be found very convenient to keep the specimens in from day to day. If the weather is warm, the ice box may have ice to keep the specimens cool. If the weather is very cold, the ice box may serve to keep the specimens from being frozen too hard, while still cold enough to be preserved.

A more satisfactory way, however, is to preserve the vertebrate specimens in one per cent formalin. Each day at the close of the study period the specimens are put into a large receptacle, like a wash boiler, galvanized iron bucket, or any other article of that nature. The next day they must be taken out and distributed, work being resumed where it had been left off.

Specimens preserved in this way will need to be tagged. Small strips of zinc written on with a lead pencil and tied to the specimen with a string have proved very satisfactory.

The principal objection to such use of formalin is that it bleaches out the blood vessels, making them difficult to trace; but it rather improves the muscles and nervous system.

For the satisfactory handling of vertebrate material, some large iron pans like baking bans (which can be procured very cheap) will be found convenient.

EARTHWORMs should be procured fresh if possible; but they may be preserved in formalin.

ClAMS AND OYSTERS can be bought in the market; but if available markets are not near, fresh-water 
clams, snails, and slugs should be collected and preserved in four per cent formalin. A supply of shells should be kept for the purpose of identifying the principal parts before beginning to study the structure of the body.

STARFish must be procured from the seashore. They are usually preserved in formalin, and will keep indefinitely. The usual cost is about two dollars per dozen.

Fresh-WATER SPONGES must be collected late in the fall; September and October are the best months. Until this season, the gemmules are not matured and the growth has not reached its maximum. For most purposes it is sufficient to dry them and then preserve them from the dust in boxes. To study the flesh and cellular structure, they should be preserved in formalin or very strong alcohol. Absolute alcohol is the best preservative of sponges when careful dissection is intended. Sponges should be dropped into absolute alcohol as soon as collected.

Hydras, DAPHNIA, CYPRIS, CYClOPS, vorTICELLA, PARAMECIUM, STENTOR, AND AMEBA would better be obtained in a fresh condition. This means that, as a general thing, these animals would better be studied in the spring or in the fall. Aquaria once stocked with them and kept in the schoolroom will usually furnish a fairly good supply of one or all of these forms. A jar, with a handful of hay put into it and let stand from year to year, will usually show several forms of protozoa, including vorticella and paramøecium.

It is better to keep all aquaria covered. - This prevents the growth of a screen of bacteria which is destructive to most other life in the aquaria. If this be done, the water will not need any changing.

Pupils should be encouraged to collect their own material and material for the class whenever possible. 
There is nothing like making the acquaintance of an animal at home; but the wise teacher will always have a supply of material on hand from which he may draw when the exigencies of the occasion demand it.

Alcohol for laboratory use may be obtained from any distillery in half-barrel or barrel quantities without paying the internal revenue tax. Permission must be obtained from the government through the internal revenue collector for the district, and a bond for double the amount of the tax must be filed with him to insure the legitimate use of the alcohol.

Each pupil should be provided with a lens, a pair of forceps, a pair of scissors, and a sharp knife or scalpel. These can be obtained for about one dollar. It is most profitable for the school to furnish these instruments.

Each pupil should also have a dissecting dish, an alcohol cup, a pair of dissecting needles, a towel, and a piece of soap. A candy tray which can be bought for ten cents makes a very good dissecting dish. A small museum jar with a tight fitting lid makes a good alcohol cup, but a wide mouthed bottle with a tight cork may be substituted. A screw capped ointment bottle does very well. The dissecting needles may be made by thrusting the eye end of a sewing needle into the end of a pine stick, whittled into the shape of a lead pencil. A notebook in which the pupil records his observations and drawings is indispensable.

A small collection of illustrative material will be found of great help. A collection of insects, showing the most common forms in the immediate vicinity, will be useful and capable of arousing great interest. The insects should be killed in a cyanide bottle, pinned with insect pins, and preserved in an insect case. A cigar box with a layer of sheet cork tacked 
in the bottom serves very well for some purposes. Spool cases, which can be obtained for a small amount of money, are more convenient. These should be prepared by lining the bottoms of the drawers with sheet cork and covering the surface of the cork with white paper ruled into squares. The squares aid very much in the arrangement of the different species. The entire drawer should be covered with a pane of glass supported by a small piece of wood at each corner. A lump of camphor kept in each drawer will effectually protect its contents from destruction by moths and dermestes. A better method, though more expensive, is to buy Comstock boxes and use the block system of keeping collections.

The wings of butterflies should be spread on a setting board. This is made by nailing two smooth pine boards, $\frac{7}{8}$ of an inch thick and two feet long, about $\frac{8}{8}$ of an inch apart. The space between them is covered by sheets of cork. This forms a grooved board with the bottom of the groove lined with cork. The butterfly is pinned through the thorax with an insect pin. This pin is stuck into the cork at the bottom of the groove. The wings are drawn out at the sides so that the hind edges of the fore wings form a straight line across the board. Strips of paper are then pinned to the board across the wings to fasten them in position until they become dry.

Individual specimens of spiders, myriapods, and insect larvæ may be kept in homeopathic vials, preserved in strong alcohol.

Snail shells are best preserved in small boxes, or in homeopathic vials if the shells are very small.

Much advantage will be derived from a series of mounted slides of parts of insects such as are figured in this book. If one knows exactly what to look for, a good deal of the structure can be made out with the hand lens. Such slides are easily prepared. Put the 
object (for example, the tongue of a fly) into strong alcohol. This should be either absolute (one hundred per cent is always preferred) or ninety-eight per cent, or even ninety-five per cent. It should then be placed on a glass slip $1 \times 3$ inches and covered with clove oil. In a few minutes the excess of clove oil should be removed with a blotter, and the object covered with a drop of Canada balsam made liquid with xylol. A cover glass is then placed on the slide, with the object in the center, and pressed down with a clamp like a spring clothes pin. In a few days the balsam near the edges will be dry, and any excess may be scraped off with a knife. The principal difficulties will be to use alcohol strong enough to remove all the water, and to avoid the inclusion of a bubble of air in the balsam.

If only one compound microscope can be had, it may be made very serviceable to a whole class by means of a porte lumiere. This is easily and cheaply made as follows: Set a board twenty inches wide across a window, under the sash. Cut a hole four inches in diameter near one edge of this, and in this hole mount a double convex lens having a focus of about twelve inches. The lens is the condenser. Directly under the lens, near the bottom of the board, cut a slit large enough to allow another board six inches wide and $\frac{7}{8}$ inch thick to pass. Let this transverse board extend about a foot outside the room. Fasten it firmly. On the outer end of the board, mount a mirror $9 \times 12$ inches in such a manner that it can be turned in two directions. Small iron rods running from the mirror frame to the inside of the window board may be used to turn and hold it.

The mirror is used to reflect sunlight upon the condenser. This concentrates the rays of light to a point at the focus. To take out the rays of heat, a tank composed of two plates of glass separated at the 
ends and bottom by a thick rubber tube and clamped together, is filled with a saturated solution of alum and set in front of the condenser.

A microscope is set on the transverse board so that the front of the object glass shall be at or near the focus of the condenser. An object is placed upon the stage, the mirror of the microscope is turned out of

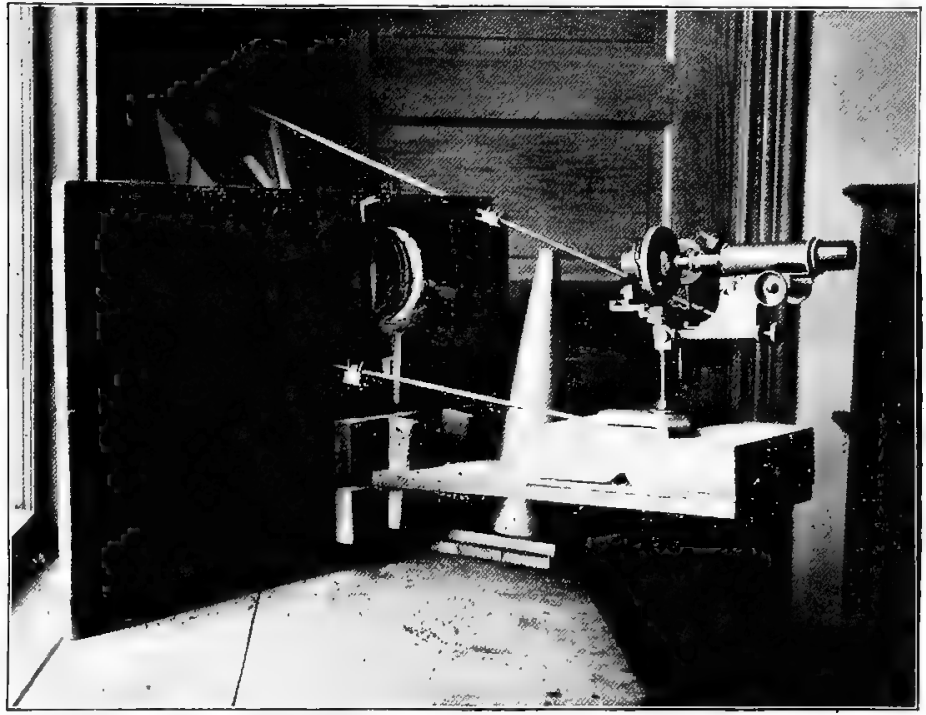

HOMEMAUE PORTE LUMIERE.

(Arranged for projecting microscopic objects.)

the way, the tube is placed horizontally, and the image is projected upon a wall or screen and focused by the microscope adjustment. The room of course must be darkened. Screens made of carpet paper or black calico are very effective; but if regular opaque shades mounted on rollers can be procured, of course they are to be preferred. With this instrument, a microscopic object is seen by a whole class at once in its natural colors. Moving objects, such as proto- 
plasm, crustaceans, vinegar worms, blood corpuscles in the tail of a minnow or in the web of a frog's foot, are shown as easily as with a mounted slide. Small glass tanks, made by cementing rubber ends and hottom to two glass slips for sides, are useful for showing living animalcules.

A picture of such an apparatus, which cost, all told, $\$ 1.54$, exclusive of the microscope, is here given. It has been found rery effectire and useful.

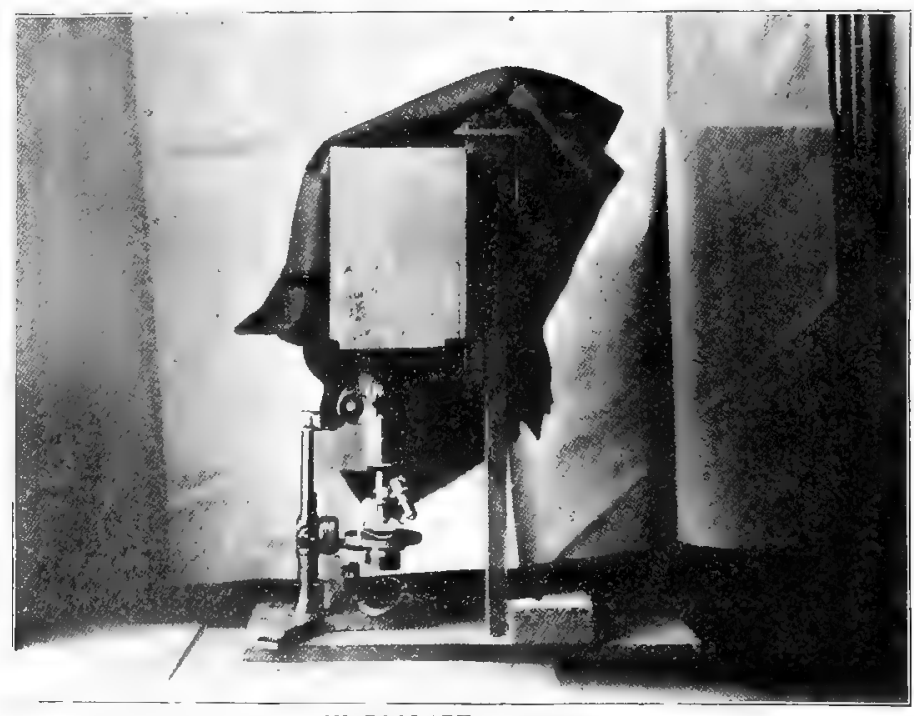

MII ROGRAPHIC CAMERA.

(Arranged for showing a microscopic object to sereral persons at once.)

Amother clerice for showing an object to a class is easily available, and a picture of this also is given. This device, called a micrographic camera, was designed and used for photographing from a microscope, but it was found to be very useful also for showing an object to half a dozn persons at once, and has been used for that purpose. 
A starch box, by means of a piece fastened to its side, is clamped to an upright piece supported on a base. The top of the starch box holds a piece ofground glass in a frame. In the bottom of the box is a hole large enough to receive the tube of a microscope.

To use the apparatus, an object is placed on the stage, the mirror reflects sunlight up the tube, the image appears on the ground glass, and is focused by the microscope adjustment. Half a dozen pupils can see the object at once if a large cloth be thrown over the heads of the whole group, thus excluding much of the light. 


\section{CHAPTER XII.}

\section{CLASSIFICATION OF ANIMALS.}

The classification of animals is in a very unsatisfactory condition. There is no general agreement among naturalists concerning it. The following arrangement of the principal groups of animals will serve as a kind of background, or map of the animal Kingdom, in which the student may locate the animals he has studied and see the extent of untraveled territory.

BRANCH I. PROTOZOA. Single-celled animals.

CLASS 1. Rhizopoda.-Amoba.

2. Sporozoa.-All parasitic.

3. Flagellata.-Each animal is provided with a

4. Infusoria.-Vorticella, Paramoecium, etc.

BRANCH II. PORIFERA. Sponges.

CLASS 1. Calcarea.-Spicules calcareous.

2. Cornacuspongia.-Fresh-water and commercial

8. Spiculispongia.-Uniaxial or tetra-axial siliceous

4. Hyalospongia-Six-rayed siliceous spicules.

BRANCH III. CELENTERATA. Animals with a permanent body cavity.

CLASS 1. Hydromedusce.-Hydra.

2. Scyphomedusce.-Jelly fishes.

3. Anthozoa.-Corals.

4. Ctenophora. Ctenophores. 
BRANCH IV. ECHINODERMATA. Rough skinned animals.

CLASS 1. Crinoidea.-Crinoids, mostly extinct.

2. Asteroidea.-Starfish.

3. Echinoidea.-Sea urchin.

4. Holothuroidea.-Sea cucumber.

BRANCH V. VERMES. Worms.

CLASS 1. Platyhelminthes.-Flat worms.

2. Nematelminthes.-Thread worms.

3. Rotatoria.-Rotifers.

4. Polyzoa.

5. Brachiopoda.-Have shells, like a clam.

6. Tunicata.

7. Nemertina.

8. Enteropneusta.

9. Gephyrea.

10. Annulata.-Earthworm, leech.

\section{BRANCH VI. MOLLUSCA.}

CLASS 1. Lamellibranchiata.-Clam, oyster.

2. Gasteropoda. -Snail.

3. Cephalopoda. - Squid.

BRANCH VII. ARTHROPODA. Jointed appendages.

CLASS 1. Crustacea.

ORDER 1. Cirripedia.-Barnacles.

2. Entomostraca.-Cyclops, etc.

3. Tetradecapoda.-Sow bug, etc.

CLASS 2. Myriapoda.

4. Decapoda.-Crawfish.

ORDER 1. Chilognatha.-Have two pairs of legs to

2. Chilopoda.-Centipede. each segment.

CLASS 3. Arachnida.

ORDER 1. Acarina.-Ticks and mites.

2. Pedipalpi.-Daddy longlegs.

3. Araneina.-Spiders.

CLASS 4. Insecta.

ORDER 1. Neuroptera.-Dragon fly.

2. Orthoptera.-Grasshopper.

3. Hemiptera.-Squash bug.

4. Coleoptera.-Beetle.

5. Diptera.-House fly.

6. Lepidoptera.-Butterfly.

7. Hymenoptera.-Bumble bee. 


\section{BRANCH VIII. VERTEBRATA.}

CLASS 1. Pisces.

ORDER 1. Leptocardii.-Amphioxus.

2. Marsipobranchii.-Lamprey.

3. Elasmobranchii.-Sharks and 1ays.

4. Ganoidei.-Garpike.

5. Teleostei.-Nearly all common fishes.

CLASS 2. Batrachia.

ORDER 1. Proteida.-Persistent gills. Proteus.

2. Urodela:-Salamander.

3. Anura.-Frog and toad.

CLASS 3. Reptilia.

ORDER 1. Ophidia.-Snakes.

2. Lacertilia.-Lizards.

3. Chelonia.-Turtles.

4. Crocodilia.-Alligator.

CLASS 4. Aves.

ORDER 1. Cursores.-Ostrich.

2. Steganopodes-Cormorant, pelican.

3. Pygopodes-Loon.

4. Longipennes.-Gulls.

5. Tubinares.-Petrel.

6. Anseres.-Geese and ducks.

7. Herodiones.-Herons.

8. Paludicoloe.-Marsh birds. Crane.

9. Limicolce.-Shore birds. Snipe.

10. Raptores, - Hawks and owls.

11. Psittaci-Parrots.

12. Gallinoe.-Chickens and turkeys.

13. Columbce.-Pigeons.

14. Coccyges.-Cuckoos.

15. Pici.-Woodpeckers.

16. Machrochires.-Humming birds.

17. Passeres.-Sparrows, etc.

CLASS 5. Mammalia.

ORDER 1. Monotremata.-Ornithorhynchus.

2. Marsupialia.-Opossum.

3. Edentata.-Sloth.

4. Rodentia.-Rabbit.

5. Insectivora.-Hedgehog, mole.

6. Cheiroptera.-Bat.

7. Cetacea.-Whales and dolphins.

8. Sirenia.-Manatee.

9. Proboscidea.-Elephant.

10. Ungulata.-Horse, cow.

11. Carnivora-Cat, dog.

12. Primates.-Monkeys, man. 


\title{
CHAPTER XIII.
}

\author{
ANALYTICAL TABLES, \\ FOR DETERMINING THE FAMILIES OF INSECTS.
}

\section{How to Use the Tables.}

The purpose of the following tables is to enable a student to find the family to which an insect belongs. Their principal value is to direct the attention of the student to the morphological differences that separate families from each other. Morphological differences are not of the greatest importance, and in some instances may seem very trivial, but they enable us to designate, easily and clearly, families that differ widely from each other in habits, life history, and economic importance. The study of type forms of animals is not sufficient in itself to give us any idea of the wealth of animal life that exists around us. Particularly is this true of insects, with their 250,000 species already described. A very little time devoted to the determination of insect families will add largely to our appreciation of their importance.

Although tables for six orders are given, it is not expected that one class will try to master all of them. It is better for one class or one student to confine himself to the insects of one order until a satisfactory familiarity with the insects of that order has been acquired.

In many instances it will be found very difficult 
to render a proper decision where an alternative is offered. There are two reasons for this: First, the student may not know the meaning of the terms employed, or have a satisfactory image of the things they represent. A study of the glossaries and the structure of the insect will help to overcome this difficulty. Second, the distinguishing mark is often one of comparison, expressed by longer, shorter, thicker, slender, somewhat, etc. This can be aided only by comparison of many insects, and will be overcome by experience.

Every teacher and every student ought to know how to use a set of analytical tables. That in itself is a valuable acquisition. Let us study how to use these. We should always make a careful examination of the specimen in hand before turning to the tables. Suppose each student has a beetle in hand. The first division of the Coleoptera is marked-

A-Head not distinctly prolonged into a beak.

It is or it is not prolonged. If it is prolonged, we omit all divisions under $\mathrm{A}$ - and go to $\mathrm{AA}$ - ; but if it is not prolonged, we read the next division,-

B-Hind tarsi with the same-number of joints as the others.

The hind tarsus either has or has not the same number as the others, so we say "Yes" or "No," according as it agrees or disagrees with the characterization in B-. If we decide "No," we turn at once to-

BB-Front and middle tarsi 5-jolnted; hind tarsi 4-jointed.

If our previous decision was right, it must fit here. Then we read-

C-Anterlor coxal cavities closed behind.

They are either closed or open. If open, we omit all intervening divisions and go at once to-

CC-Anterior coxal cavities open behind. 
Next we go to the first division under $\mathrm{CC}-$, which isD-Head not suddenly and strongly constricted at the base.

We must determine first what is meant by suddenly and strongly constricted at the base, and here some known examples will help us greatly. Suppose we decide that the head is suddenly and strongly constricted. We say "No," to D- and proceed to DD-. The first division under DD- is-

E-Lateral sutures of the thorax distinct; base as wide as the elytra.

If we say "No" to this, we go to-

EE-Lateral sutures of the thorax wanting.

The first division under this is-

F-Tarsi perfect, with distinet claws; eyes normal; prothorax at the base narrower than the elytra.

An examination of $\mathrm{F}-, \mathrm{FF}$-, and $\mathrm{FFF}$ - shows that the narrow prothorax distinguishes $\mathrm{F}$ - from $\mathrm{FF}$-, and the eyes normal, with distinct claws, distinguishes F- from FFF-. Suppose we say "Yes" to this character, we go to-

G-Hind coxæ not prominent.

If we decide that the hind coxæ are prominent, we go to $\mathrm{GG}$-, the first division of which is-

H-Claws simple; head horizontal.

If we say "No" to this, we go to-

HH-Claws cleft or toothed; front of head vertical,-

and at the end of this line we find, in parenthesis, the name of the family, Meloidæ, which is the family of blister beetles, all of which have a very curious life history.

Half a dozen beetles traced through in this way will give us a very fair understanding of the tables.

The names of the families all end in -idæ, and the accent falls on the syllable just before this termination. 


\section{Table for Determining the Orders of Insects.}

A- Mouth parts fitted for biting.

$\mathrm{B} \rightarrow$ Fore and hind wings of different texthres.

C-Fore wings hard and horny, not useful for flying; hind wings membranous, naked, folding longitudinally and transversely. Beetles.

(Coleoptera.)

$\mathrm{CC}$-Fore wings leathery, sometimes wanting; hind wings membranous, folding longitudinally; direet metamorphosis..... .... (Or'thoptera.)

BB-Fore and hind wings similar in texture, but seldom folding. (Neuroptera.)

A.A-Mouth parts tltted for sucking, lapping, or piercing.

B-Wings only two, hind wings rudimentary.

BB-Wings four.

C-Wings clear with few veins; biting mandibles present. (Hymenoptera.)

CC-Wings scaly; mouth parts a long, coiled sucking tube. (Lepidoptera.)

CCC-Wings either membranous, or front pair horny at the base; mouth with a jointed beak................................ (Hemiptera.)

\section{Table for Determining the Families of Orthoptera.}

A-Hind legs enlarged and fitted for leaping.

B -Antennæ much shorter than the body; ovipositor short; auditory organ on the abdomen..................................(Acridida.)

BB-Antennæ much longer than the body; auditory organ on the fore legs.

C-Tarsi composed of three segments; abdomen with long, hairy anal stylets; color generally brown or black. Crickets .............. (Gryllidæ.)

CC-Tarsi composed of four segments; anal stylets short; ovipositor flat or sword-shaped; color generally green. Katydids.......... (Locustidæ.)

AA-Hind legs not fitted for leaping; tarsi of fire segments.

B-Fore legs enlarged and fitted for grasping; head transverse, wider than the thorax; thorax greatly elongated.... .................. (Mantidæ.)

BB-Legs all nearly alike and titted for walking; head exposed and not especially wider than the thorax; body greatly elongated. Walking

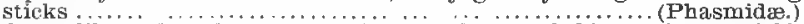

BBB - Legs alike and used for locomotion; head concealed beneath the shieldshaped prothorax; body flattened. Cockroaches...........(Blattidæ.)

\section{Table for Determining the Families of Hemiptera.}

(Arranged by permission from Comstock's Entornology.)

A-Beak jointed; with or withont wings.

B -First pair of wings thickened at the base, thinner at the tip.

C-Antenne shorter than the head, and nearly or quite concealed in a cavity beneath the eyes.

D-Hind tarsi without claws.

E-Fore tarsi flattened, with a fringe of hairs on the edge, and without claws. Head overlapping the prothorax................ (Corisida.)

EE-Fore tarsi of the usual form, and with two claws; head inserted in the prothorax .............................. (Notonectide.)

DD-Hind tarsi with two claws.

E-Caudal end of the abdomen furnished with a respiratory tube composed of a pair of grooved thread-1ike organs............ (Nepidæ.)

EE-Abdomen without respiratory tube.

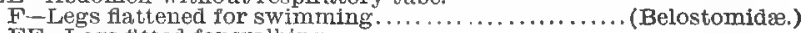

FH-Legs titted for walking.

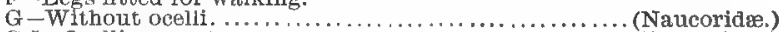

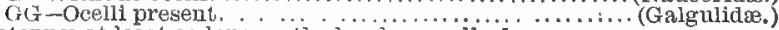

('C-Antenna at least as long as the head; usuaily free."

D-Body linear; head as long as the three thoracic segments.

DD - Body of various forms, but when limear, with the head shorter than the thorax.

E-Last segment of the tar i more or less split, and with the claws inserted before the apex.

$\mathrm{r}-$ Boily usually elongated; prothorax narrow; beals 4-jolnted; second and third pair's of legs (xitrinuly long and slender. (Hydrobatida.) 
IFI-Body stout, oval, and broadest across the prothorax; beak 3 jointed; legs not extremely long................. (Veliidw.)

IE-Last segment of the tarsi entire, and the claws inserted at the apex.

F-Antennæ 4-jointed.

G-Wing covers resembling net work; not much distinction between corium and membrane ........................ (Tingitidxe.)

GG-Wing covers not as above.

H-Beak 3-jointed.

I-Wing covers, when well developed, with a cuneus; when not well dereloped, no ocelli.... ................ (Acanthjidæ.)

II-Wing covers, when well developed, without a cuneus; when not well developed, ocelli present.

$J$-Ocelli wanting.

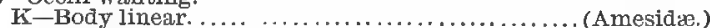

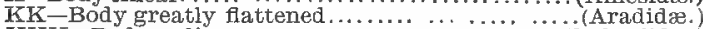

KKK-Body ordinary ........................ (Reduviidie.)

JJ-Ocelli present.

K-Beak very long, reaching to or beyond the intermediate coxpe.

KK-Beak not reaching intermediate coxa.

L-Femora of front legs greatly thickened... (Phymatidae.)

IL-Front femora little thickened, less than half as wide

HH Beak 4-jointed.

as long................................. (Reduviida.)

I-Front legs fitted for grasping prey ................ (Nabidæ.)

II-Front legs fitted for walking.

J - Wing covers with cuneus, almost without veins. (Capside.)

JJ-Wing covers without cuneus, membrane with four or five veins.

$\mathrm{K}$-ocelli wanting....................... (Pyrrhocoridæ.)

KK-Ocelli usually present.

$\mathrm{L}-\mathrm{Head}$ with a transverse incision in front of the ocelli

LL-Head without transverse incision.

(Berytidae.)

M-Membrane with four or five simple veins arising from the base of the membrane ............. (Lygæeidre.)

MM-Membrane with many usually forked veins arising

FF-Antennæ 5-jointed from the transverse basal vein .......... (Coreida.)

G-Scutellum uearly flat, narrowed behind.

H-T'ibixe unarmed, or furnished with very short spines.

HH-Tibiæ armed with strong spines. .................(Cydnidie.)

GG-Scutellum very convex, covering nearly the whole of the abdomen.

$\mathrm{H}$-Lateral margins of the scutellum with a furrow in which the edge of the wing cover fits when closed ... ... (Corimelaunida.)

HH-Lateral margins of the scutellum without a furrow.

BB-Wings of the same thickness throughout.

(Scutelleridae.)

C-Beak evidently arising from the head; tarsi 3-jointed; antennæ minute, bristle-like.

D-Three ocelli, males musical; wings entirely membranous; large insects.

DD-Ocelli two or wanting; males not musical.

(Cicadidre.)

E-Antennæ inserted on the sides of the cheek beneath the eyes.

EE-Antenna inserted in front of and between the eyes.

(F'ulgorida.)

F-Prothorax not prolonged above the abdomen.

$\mathrm{G}-$ Hind tibire with one or two stout teeth, and the tip crowned with

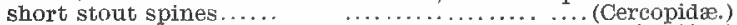
GG-Hind tibia having a row of spines below........... (Jassidæ.) FF-Prothorax prolonged into a horn or point above the abdomen. (Membracida.)

CC-Beak apparently arising from between the front legs, or absent; tarsi one or two-jointed; antennæe, usually prominent and thread-like, sometimes wanting.

D-Tarsi usually two-jointed; wings when present four in number. 
E-Wings trinsparent.

F-Hiцd legs titted for leaping; antennæ nine- or ten-jointed.

FF-Legs long and slender, not titted for leaping; antenn (Psyrisa. seven-jointed ..................................... (Aphididæ.)

EE-Wings opaque, whitish; wings and body covered with a whitish

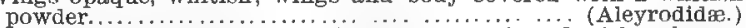

DD--Tar'sí one-jointed; adult male without any beak and with only two wings; female wingless. Scale insects.................(Coccidæ.) AA -Wingless; fieshy, unjointed beak. Lice................... (Pediculidæ.)

\section{Glossary for the Table of Hemiptera.}

Caudal-towards the tail, or posterior part.

Corium-the thickened basal portion of the fore wings.

Cuneus-a triangular portion of the terminal part of the corium marked off from the rest by a line.

Membrane-the thin posterior portion of the fore wings.

Scutellum - the triangular piece on the back between the bases of the fore wings.

\section{Table for Determining the Families of Nenroptera.}

(Odonata, Ephemerida, Corrodentia, Plecoptera, Isoptera, Mecoptera, Neuroptera, Trichoptera, Mallophaga.)

A-Wingless, or with rudimentary wings.

$B \rightarrow$ mouth parts fitted for biting.

C-Head with a long trunk-like beak. ..................... (Panorpidæ.)

CC-Head not prolonged into a trunk.

D-Louse-like insects.

E-Antennæ not more than five segments. Bird lice... (Mallophagidæ.)

EE - Antennæ with many segments, Book lice.. ............ (Psociaæ.)

DD-Not louse-like; abdomen sessile; legs not fitted for jumping; body

AA - Winged. white and somewhat ant-like in form................ (Termitidx.)

B--With two membranous wings; abdomen with caudal filaments; mouth parts rudimentary; halteres wanting.................. (Ephemeridæ.)

BB-With two pairs of wings. Wings similar, membranous.

$\mathrm{C}-$ Wings net-veined, with many veins and cross veins.

D-Tarsi consisting of less than five segments.

E -Aptennie inconspicuous, awl shaped, short, and slender.

F-First and second pair of wings nearly the same length; tarsi threejointed. Dragon flies .... .................. (Libellulidæ.)

FF-Second pair of wings either smail or wanting; tarsi four-jointed.

EE-Antennæ usually conspicuous, not awl shaped and'slender.

(Ephemeridæ.)

F-Tarsi two- or three-jointed.

G-Second pair of wings the smaller ...................(Psocida.)

GG-Second pair of wings broader, or at least of the same size as the first pair .................................. (Perlida.)

FF-Tarsi four-jointed, wings equal ................... (Termitida.)

DD-Tarsi consisting of five segments.

E-Abdomen with setiform, many-joinced anal flaments.

EE-Abdomen without many-jointed anal filaments.

(Ephemeridx.)

F-Head prolonged into a trunk-líke beak ............(Panorpida.)

FF-Head not prolonged into a beak.

G-Prothorax as long as or longer than the meso-and meta-thorax combined.

$\mathrm{H}-$ Fore legs greatly enlarged and litted for grasping.

HH-Fore legs not enlarged and not fitted for grasping.

(Mantispidæe.)

(Raphidilda.)

GG-Prothorax not so long as the meso- and meta-thorax combined. 
H-Hind wings broad at the base, and the part nearest the body folded like a fan when not in use ................. (Sialidæe.)

HH-Hind wings narrow at the base and not folded.

I-Antennæ knobbed, or enlarged, toward the end.

II-Antennæ without terminal enlargement.

(Myrmeleonidæ.)

J-Some of the transverse veins between the costa and subcosta forked; wings brownish or smoky ... .... (Hermerobiidæ.)

JJ-Transverse veins between the costa and subcosta simple; wings greenish ....................... (Chrysopidæ.)

CC-Wings with branching veins and comparatively few cross veins or veinless.

D -Tarsi two- or three-jointed.

E-Posterior wings smaller than the anterior

EE-Posterior wings as large as or larger than the anterior ones.

DD-Tarsi four- or five-jointed.

E-Abdomen with setiform, many-jointed anal filaments. (Ephemeridz.) EE-Abdomen without many-jointed anal filaments. Second wings as large as or larger than the first. Moth-like insects. (Phryganeida.)

Although in the above table all the families included have been grouped into one order of Neuroptera, the differences existing among them are so very great that they are more properly separated into several orders. The following table will indicate the orders to which the several families belong.

\section{ORDERS. FAMILIES.}

Odonata .......Libellulidæ.-Dragon flies

Plecoptera ..... Perlidæ.-Stone flies

Isoptera........ Termitidæ. - White ants

Corrodentia .... Psocidæ.-Book lice

Mallophaga .... Mallophagidæ.-Bird lice

Mecoptera .....Panorpidæ.-Scorpion flies

Trichoptera ....Phryganeidæ.-Caddice flies, or Caddice worms

Sialidæ.-Horned corydalis

Raphidiidæ.-Found only in the far west

Mantispidæ.-Somewhat like praying mantis

Neuroptera.. $\left\{\begin{array}{l}\text { Mantispidæ.--Somewhysopidæ.-Lace-winged flies } \\ \text { Chrysom }\end{array}\right.$

Hemerobiidre.

Myrmeleonidæ, - Ant lions

\section{Table for Determining the Families of Diptera.}

(Arranged by permission from Williston's North American Diptera.)

A-Head separated from the thorax by a neck; never parasitic.

B-Antennte many-jointed, of ten longer than the thorax.

C-Dorsum of the thorax with a complete V-shaped suture...... (Tipulidæ.) 
CC-Dorsum of the thorax withont a V-shaped suture.

D A complete discal cell prenent.

DD-No discal cell.

E-Antenna composed of three joints, with a terminal arista.

FE-Antenna apparently not composed of three joints (Orphnephilidæ.) arista.

F - Wings with only a few longitudinal veins and no cross veins.

FF-Wings usually many-veined.

(Cecidomyidæ.)

G-Ocelli present.

H-Wings broad, bare, marked by numerous folds between the reins, giving a ne ied, spider web-like appearance.

HH-Wings not so marjzed.

(Liponeuridæe.)

I Coxæ much elongated....................... (Mycetophilidæe.)

II Coxa short. ....................................... (Bibionida..)

GG--Ocelli wanting.

$H$-Costal or marginal vein not extending beyond the tip of the wing.

I-Antennæ slender, the joints more or less constričted, and often bushy plumose; legs slender, hind tibice and metatarsi never dulated; abdomen slender; wings narrow.... (Chironomidæ.)

II-Antenna shorter than the thorax; never hairy; legs strong, hind pair dilated; body thick-set; wings broad.

HH-Marginal vein encompassing the whole wing.

(Simuliidæ.)

I-Wings ovate, with ten longitudinal veins and no cross reins.

II-Wings with cross vein near the middle.

(Psychodiaze, )

$\mathrm{J}-\mathrm{W}$ ings hairy, fringed on the margin. Mosquitoes.

JJ-Wings bare; the second vein arises near the (Culicida.) wing. . . .......................... (Dixidæ.)

BB-Third joint of antenne complex; basal cells of the wing long.

C-Empodia developed pulvilliform.

D-Alulæe rather large; third longitudinal vein forked. Horseflies.

DD-Alulæ small or rudimentary. Mostly flower flies.

(Tabanidæ.)

E-Tibiæ wholly without spurs; costal vein not reaching beyond the tip of the wing . ................................ (Stratiomyidx.)

EE-Midale tibiæ, at least, with spurs; costal vein encompassing the whole wing........................................ (Leptidie.)

BBB--Antennæ composed of three simple joints:

C-Antenure apparently composed of a single joint with a long bristle; femora

flattened, hind legs long. Small, quick-running, hump-backed fies.

$\mathrm{CC}-\mathrm{Not}$ such flies.

(Phoridæ.)

D--Empodia developed pulvilliform; that is, three nearly equal membranous appendages on the under side of the claws.

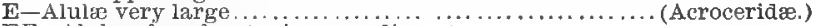

FE-Alula of moderate size or rudimentary.

F-Middle tibix, at least, with spurs; no bristles on femora or tibire; third longitucinal vein forked; five posterior cells present; anterior cross vein always distinct; third joint of the antenne with a bristle, or slender siyle, usually terminal............. (Leptida.)

FF-Not such flies.

G-Third longitudinal vein forked, two or more submarginal cells present.

H-Arista, or style of antennæ, always present and dorsal.

I-Head comparatively small; proboscis more or less elongated.

(Empidæe.)

H.H - Arista terminal or absent.

I-Vertex and front distinctly hollowed out between the eyes. Mostly large flies.

J-Proboscls with fleshy labella at the tip; palpi rudimentary or wanting................................. (Mydaida.) 
JJ--Proboscis without fleshy labellas at the tip; palpi usually prominent ............................... (Asilidg.)

II-Vertex and front plane or convex.

$\mathrm{J}$-Never more than four posterior cells in the wing.

$K$-Third antennal joint without bristle, or style; fourth longitudinal vein terminating at or before the tip of the wing. (Scenopidæ.)

KK-Third antennal joint usually with terminal style; fourth longitudinal vein terminates beyond the tip of the wing.

L-Anal cell narrowly open or closed near the margin; discal cell present ...........................(Bombylidx.)

LL-Anal cell closed remote from the border, or the discal cell is wanting.......................... (Empidæ.)

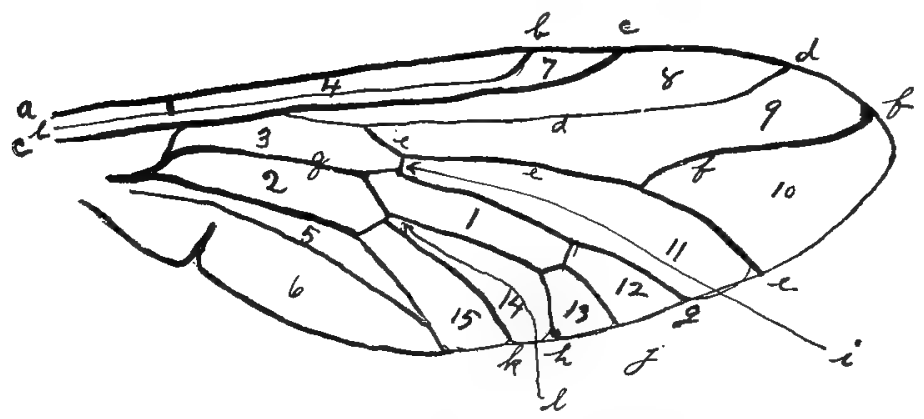

WING OF HORSE FIS (TABANUS.)

1.-Discal cell.

2.-Second basal cell.

3.-First basal cell.

4.-Costal cell.

5.-Anal cell.

6.-Auxiliary cell.

8.-Marginal cell.

9.-First submarginal cell.

10.-Second "

11.-First posterior cell.

12.-Second

13.-Third

14.-Fourth

15. - Fifth
a.-Costal vein.

b.-Auxiliary vein.

c.-First longitudinal vein.

d.-Second

e.-Third

f.-Anterjor branch of third vein.

g. - Fourth longitudinal.

h.-Fifth

i.-Anterior cross vein.

j. - Anterior intercalary vein.

k.-Posterior intercalary vein.

1.-Posterior cross vein.

JJ-Five posterior cells in the wing.

$K$-Neuration intricate; anterior cross vein wanting or rudimentary ..................... (Nemistrinidæ.) KK-Neuration not intricate; anterior cross vein al ways distinct.

L-Fourth vein terminates beyond the tip of the wing:

LL_Fourth vein terminates before the tip of the wing.

GG-Third longitudinal vein not forked.

(Apioceridæ.)

H-Antenna with a terminal arista, or styte.

I-Wings pointed, no cross veins in the middle. (Lonchopterida.)

II-Wings rounded, not lancet-like. 
J-Second basal cell confluent with the discal cell, not separated by a vein.......................... (Dolichopodidxe.) JJ-Second basal cell separated from the discal cell by a vein.

K-Antenna with a terminal bristle.

L-Head comparatively small; proboscis more or less elongated; alulæ of the wings usually rudimentary.

(Empidæ.)

LL-Head bload as the thorax; Proboscis fleshy; alulæ distinct . ..................... (Platypezidæ.)

KK-Antenna with a terminal style.

L-First posterior cell open ............... (Empida..)

M-Face convex transversely or with a median ridge, never with a subantennal depression.

N-A spurious longitudinal vein, between the third and fourth longitudinal veins, erossing the anterior cross vein .......................... (Syrphidæ.)

NN -Spurious vein never present........(Pipunculidæ.) MM-Face with subantennal grooves or depressions.

N-Proboscis horny and elongate, often folding back near the niddle; abdomen never with bristles.

(Conopiare.)

NN-Proboscis fleshy and not elongate; if elnngate and slender, the body with distinct bristles, or the bristle of the antenna plumose. ...... (Muscidae.)

HH-Antenna with a dorsal arista.

I-Proboscis rudinıentary; palpi wanting. Bot flies. (Oestridæ.)

II Proboscis not rudimentary; palpi present.

J-Second basal cell confluent with the discal cell. Small, bri]liant colored, preaaceous flies ... ....... (Dolichopodidx.)

JJ -Second basal cell separated from the discal cell by a small cross vein.

$\mathbf{K}-\mathrm{Basal}$ cell of the wing elongate, anal cell closed toward the margin.

L-Face convex transversely or with a median ridge, never with a subantennal groove or depression.

$\mathbf{M}-\mathbf{A}$ spurious longitudinal vein, between the third and fourth longitudinal veins, crossing the anterior cross vein. ......................... (Syrphidx.)

MM-Spurious vein never present.......... (Pipunculidæ.)

LL-Face with subantennal ver'ical grooves or depressions.

M-Proboscis horny and elongate; abdomen never with bristles ............................ (Conopida)

MM-Proboscis tleshy and not elongate; if elongate and slender, the body with distinct bristles, or the bristle of the antenna plumose ......... (Muscidæ.)

AA-Parasitic flies.

KK-Posterior basal cell small; anal cell always closed remote from the margin........ (Conopidæ or Muscidæ.)

B--Parasitic on bats.............................. (Nycteribidæ.

BB-Parasitic on birds or mammals ....................... (Hippoboseldx.)

NoTE.-The famlly of Muscidre includes nearly one-third of all the flies. By some dipterologists it is divided into about twenty-one groups which may be called families.

\section{Glossary for the Table of Diptera.}

Dorsum-the dorsal or upper side of the body.

Discal cell-see figure of the wings.

Alule -the backward, membranous extension of the wings.

Pulvillus - one of the two pad-like, fleshy eushions between the claws.

Empodium - the middle appendage of the foot between the claws. Sometimes pad-like, sometimex bristle like, sometimes wanting.

Hefutarsus - the Hrst joint of the tarsus; usually larger than the other regrnents.

Plumose - furnished with long, soft, fouther-like hajrs.

Arista-a bristle, or strong hair, growing on the intenni. 


\section{Table for Determining the Families of Coleoptera.}

(Adapted from LeConte and Horn's Classification of the Coleoptera of North America.)

A -Head not distinetly prolonged into a beak.

B-Hind tarsi with the same number of joints as the others.

C-Fourth and tifth tarsal joints not connate.

D-First ventral segment divided by the hind coxal cavities, so that the sides are separated by the very small medial part.

E-Metasternum with an antecoxal piece, separated by a well marked suture, reaching from one side to the other, and extending in a triangular process between the hind coxæ.

F-Antenna 11-jointed; habits terrestrial.

G-Antennæ arising at the side of the head between the base of the mandibles and the eyes........................... (Carabidæ.)

GG-Antennæ inserted on the front above the base of the mandibles.

FF-Antennæ 10-jointed; habits aquatic; hind coxæ fixed and with large plates almost entirely concealing the abdomen.

(Haiiplidø.)

EF-Metasternum without antecoxal piece, prolonged into a triangular process posteriorly; habits aquatic.

F-Antennæ slender, filiform or setaceous; abdomen with six segments; eyes two ................................ (Dytiscidæ.)

F'F-Antennie irregular, very short; abdomen with seven segments; eyes four. . ................................ (Gyrinidæ.)

DD First ventrai segment visible for its entire breadth.

E-Antennæ clavate or capitate, not lamellate........... (Clavicornidæ)

F-Dorsal segments of the abdomen entirely corneous; elytra usually short.

G-Abdomen flexile, ventral segments eight ........ (Staphylinidæ)

GG-Abdomen not texile, segments five or six.......... (Pselaphidæ.)

FF-Dorsal segments of the abdomen partly membranous; elytra ustally long.

G-Tarsi five-jointed, at least on one pair of tarsi.

H-Mentum large, quadrate; palpi distant at the base; habits usually aquatic. ... .................(Hydrophilidæ.)

HH-Mentum moderate or smali; labiai paipi approximate at the base.

I-Ventral segments 1-3 connate.

$\mathrm{J}-\mathrm{Fifth}$ joint of tarsi longer than the others combined; claws large .... .............................(Parnidæ.) JJ-Fifth joint of tarsi not longer than others combined; claws usual. ..............................(Rhyssodidæ.)

II-Ventral segments free.

J-Anterior coxæ large, conical, prominent.

K-Posterior coxw more or less conical and prominent.

L -Eyes finely granulated, sometimes absent..... (Silphidæ.)

LL L-Eyes coarsely granulated.............. (Scydmænidæ.)

KK-Posterior coxæ not prominent.

L-Antennæ moderate in length. capitate; posterior coxæ sulcate for the thighs; body usually scaly or pubescent.

(Dermestidæ.)

LL-Antenne long, slender, sometimes capillary; last ventral segment elongate; tarsi long and slender.

(Scaphidiidæ.)

JJ-Anterior coxæ conical, transverse, slightly prominent; prothorax strongly toothed on the sides....(Derodontidæ.)

JJJ-Anterior coxæ not prominent.

K-Anterior coxæ rounded or oval.

L-Posterior coxw not sulcate for the reception of the thighs.

M-Posterior coxæ contiguous............(Phalacridæ.)

MM-Posterior coxie separated.

N-First ventral segment more elongated...... (Ptinidæ.)

NN-Ventral segments sub-equal.

$\rho$-Middle coxal cavities open externally ...(Cucujidæ.) 
OO-Midale coxal carities closed by the sterna.

P-Prosternum not prolonged behind.

PP-Prosternum prolonged behind meeting the mesosternum.

Q-Anterior coxal cavities open behind.

QQ-Anterior coxal cavities closed behind. (Cryptophagida.)

LL-Posterior coxpe sulcate to receive the thighs. (Erotylidæ.)

KK-Anterior coxæ transverse.

(Throseldæ.)

L-Posterior coxæ flat, not sulcate to receive the thighs.

M-Antennæ straight.

N-Tarsi more or less dilated, first joint not short.

(Nitidulidæ.)

NN-Tarsí slender, first joint short. ... . (Trogositidæ.)

MM-Antennae geniculate; tibire usually all dilated.

(Histeridæ.)

LL-Posterior coxa grooved for the reception of the thighs; body oval, convex, legs retractile......... (Byrrhidæe.)

GG-Tarsi four-jointed.

$\mathrm{H}$-Wings fringed with hairs; very small species.... (Corylophidæ.)

HH-Wings not fringed with hairs.

I-Ventral segments 1-4 connate.

J-Antennæ regular: legs not fossorial............ (Colydiidæ.)

J.J - Antennæe short, irregular; legs fossorial.....(Heteroceridæ.)

II-Ventral segments free.

J-A Aterior coxis trinsverse .................. (Nitidulidæ.)

JJ-Anterior coxæ globose.

$\mathbf{K}$-Tarsi slender. ...................... (Endomychidæ.)

$K K$-Tarsi more or less dilated and spongy beneath.

JJj-Anterior coxp oval,

(Erotylidre.)

K-Form depressed; head, free. ........... (Mycetophagidæ.)

KK-Body cylindrical, thorax prolonged over the head.

GGG-Tarsi 3-jointed,

(Ciidæe.)

H-Wings fringed with long hairs; abdomen with 6 or 7 ventral segments; antennx slender, verticillate, minute species.

HH - Wings not fringed.

(Trichopterygida.)

I-Tarsi with the second joint dilated.

J-Claws appendiculate or toothed; first ventral segment with coxal línes........................ (Coceinellidæ.)

JJ-Claws simple ; first ventral segment without coxal lines.

II--Tarsi with second joint not dilated.

(Endomychidie.)

J-Elytra entire; ventral segments nearly equal. (Lathridida.) JJ-Elytra truncate; ventral segments 1 and 5 longer.

FE-Antenno serrate.

(T'rogositida.)

F-FIrst and second ventral segments connate; tarsi with membranous lobes. .................................... (Buprestida.)

FF-Ventral segments free.

G-Tursi 4-jointed...

GG-Tarsi 5-jointed.

H-First ventral segment elongated; antennæ terminated by a two-jointed elub.............................. (Ptinide.)

HH-First ventral segment not elongated,

I-Hind coxa sulcate to recelve the thtghs.

J-Front coxe globose.

K-Prothorax loosely articulated; prosternum prolonged behind; front coxal cavities entirely prosternal.

(Elaterida.)

kK-Prothorax firmly articulated; front coxal cavities closed behind by mesosternum: antonnto sometimes with a 3. jointed club................... (Throscida.) 
J J-Front coxæ transverse.

K-Onychium swall, or wanting.

L-Head not constricted behind; eyes granulated. Mesothoracic epimera reaching the coxæ..... (Dascyllidue.)

LL-Head not constricted behind; eyes granulate; Mesothoracic epimera not reaching the coxse. (Ptinidæ.)

LLL-Head constricted behind; eyes smooth. (Cupesidæ.) KK - Onychium large and hairy.............. (Rhipiceridæ.) II-Hind coxæ flat, not sulcate.

J-Prosternum not prolonged behind; tarsi with membranous lobes.................................(Cleridæ.

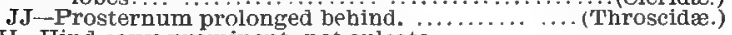
III-Hind coxæ prominent, not sulcate.

J -Front coxæ large, globose, without trochantin. (Ptinidæ.) JJ-Front coxæ long, with distinct trochantin.

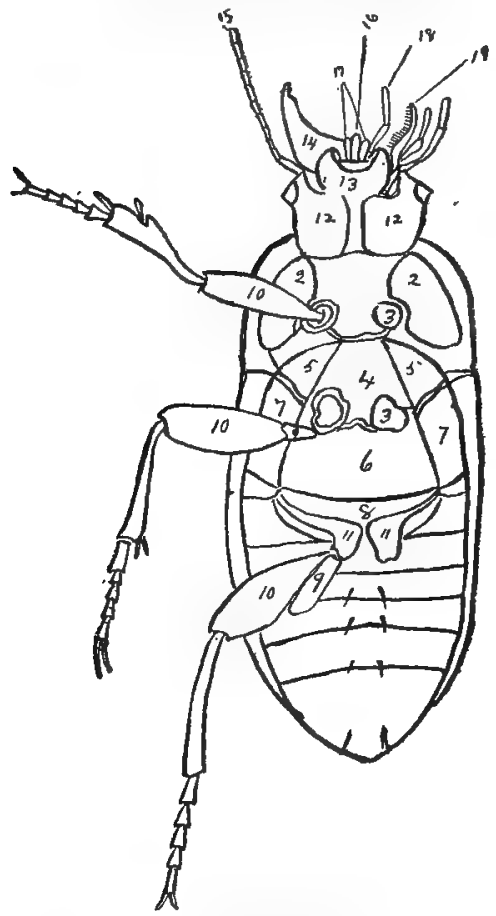

VENTRAL SIDE OF HARPALUS CALIGINOSUS.

1.-Prosternum.

2.-Prosternal episternum.

3.-Coxal cavities, closed behind.

4.-Mesosternum.

5.-Mesosternal episternum.

6.-Metasternum.
7.-Metasternal episternum.

8.-Antecoral piece.

9.-Trochanter's.

10.-Femora.

11.-Posterior Coxa.

12.-Gula, with the gular sutures.
13.--Mentum.

14.-Mandible.

15.-Antenna.

16. - Ligula.

17.-Paraglossie.

18. - Labial palpus.

19.-Maxillia. 
$\mathrm{K}$-Ventral segments 7 or $8, \ldots \ldots \ldots \ldots \ldots \ldots$ (Lampyrida.)

KK-Ventral kerments 5 or 6. (Malachida.)

EET-Antenna with a lamellate club; legs fossorial.

F-Lamellre of club not capable of close apposition, and usually not flattened. ............................. (Lucanidæ.)

FF-Lamellæ of club of antenna capable of close apposition, and flattened. ........................ (Scarabeidie.) (C-Fourth and fifth taisal joints grown together, the fourth very small, hence apparently 4-jointed; Antenna filiform, rarely serrate, or feebly thickened externally.

D-Tarsi dilated and spongy beneath.

E-Antennie usually long or greatly developed, frequently inserted on frontal prominences; front often vertical, large and quadrate; pronotum rarely margined; tibial spurs distinct. (Cerambycidæ.)

EE-Antennæ moderate or short, not inserted on frontal prominences; front small, oblique, sometimes inflexed; pronotum most frequently margined; tibial spurs usually wanting.

(Chrysomelidæ.)

EEE-Front prolonged into a broad, square beak; anteunze inserted in front of the eyes, variable in length serrate or pectinate.

(Bruchidæ.)

DD-Tarsi not dilated; sensitive surface in deep impressions. (Spondylidæ.)

BB-Front and middle tarsi 5-jointed; hind tarsi 4-jointed.

C-Anterior coxal cavities closed behind.

D -Tarsal claus simple.

E-Penultincate joint of the tarsi not spongy. ........... (Tenebrionidæ)

EE-Penultimate joint of the tarsi spongy beneath............ (Lagriidæ.)

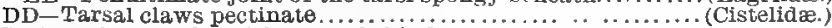

CC-Anterlor coxal cavities open behind.

$\mathrm{D}-$ Head not suddenly and strongly constricted at the base.

E-Middle coxæe not very prominent.

F-Thorax margined at the sides.....................(Melandryidæ.)

FF-Thorax not margined .................................... (Pythidæ.)

EE-Middle coxæe very prominent..................... (Ederieridis.)

DD-Head suddenly and strongly constricted at the base.

E-Lateral sutures of the thorax distinct; base as wide as the ely tra.

F-Hind coxæ laminiform ............................. (Mordellidæ.)

FF-Hind coxæ not laminiform.................... (Melandryid . $^{\text {. }}$

EE-Lateral sutures of the thorax wanting.

F--Tarsi perfect, with distinct claws; eyes normal; prothorax at the base narrower than the elytra. .................... (Anthicidæ.)

G-Hind coxe not prominent.

GG-Hind coxa large, prominent.

H-Claws simple; head horizontal .................. Pyrochroidæ.

HH-Claws cleft or toothed; front of head vertical....... (Meloidx.)

FF-Tarsi with distinct claws; eyes normal; prothorax at the base as

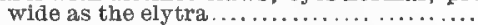

FFF-Tarsi without claws; eyes pedunculated . (Rhipiphoride.

AA--Head more or less prolonged into a beak; palpi rirrid and labrum wanting (except in Anthribidæ); gular sutures entirely conflutat along mediau line; prosternal sutures wanting.

B--Antennue straight, filform ......

BB-Antennæ clavate, often geniculate.

C-Elytra without any fold, or with a very feeble one on the inner surface near the edge: male and female pygldinm alílse.

D-Labrum wanting; mandible flat, toothed on the inner and outer sides.

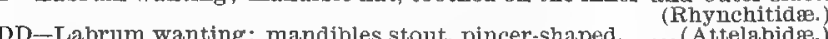

DD-Labrum wanting; mandibles stont, pincer-shaped. ..... (Attelabidæ.)

CC-Elytra with a strong fold on the inmer surface.

D-Pygidium of the male divided.

E-Tarsi setose, or spinose beneath, narrow .............. (Byrsopida.)

EE-Tarsi usually dilated, brush-like beneath.

F-Mandibles with a decilluous piece, which is lost soon after coming out of the pupa state, and leaves a se'ar ........... (Ot ior'hyuchide.)

FF-Mandibles without an accessory piece............... (Curculionida.)

DD-Pygidium of both sexes undivided.

E-Pygidium surrounded at the edge by the elytra; tibia usually serrate.

(Scolytidue.) 
EE-Pygidium normal, covered or uncovered; tibiæ not serrate.

F-Antennæ geniculate; labrum wanting. ............... (Calandridæ.) FF-Antennæ straight, 10- or 11-jointed; labrum distinct.

(Anthribidæ.)

\section{Glossary for the Table of Coleoptera.}

Ante-coxal piece-a piece of the sternum just in front of the coxa. Apposition-position of being placed together. Capitate-knobbed, or enlarged at the tip; said of the antennæ. clavate-terminal joints gradually increasing in size; said of the antennæ. Connate-grown together so as to be immovable upon each other.

Constricted-narrowed very suddenly.

Contignous-close together, so as to touch.

Coxal cavity-the depression in the sternal plate into which the coxa is inserted.

Eyes pedunculated-eyes set in short stalk, or peduncle.

Filiform-threal-like; said of the antennæ.

Fossorial-Fitte 1 for digging.

Geniculate-elbowed; the second joint so attached that it makes an angle with the first, the succeeding joints continuing in line with the second.

Glo3ose-round, somewhat like a ball, or globe.

Gula -the under side of the head, just behind the mentum. It constitutes the principal part of the under surface of the head.

Gular sutures-the lines in which the two halves of the gula are joined together or to a middle piece.

Lamello -thin, Hat plates.

Laminiform - having the form of thin flat plates.

Lamellate-terminal joints flattened so as to present flat surfaces to each other; said of the antennde.

Mentum-that part of the under side of the head which lies immediately behind the mouth.

Metasternum-sternum of the metathorax.

Onychium - a small appendage between the claws.

Pectinate-toothed like a comb; said of the antennæ.

Penultimate-next to the last.

Pronotum - dorsal side of the prothorax.

Pubescent-covered with fine hairs.

Pygidium - the last dorsal segment of the abdomen.

Setaceous-huir-like; said of the antennæ.

Serrate-toothed like a saw.

Setose-furnished with many hairs.

Spinose-furnished with many spines.

Sterna-plural of sternum; under side of the thorax and abdomen.

Suleate-grooved.

Suture-a line in which one piece joins another.

Thorax margined-furnished with a thin edge, or shelf, projecting from the thorax outward.

Trochantin-an accessory piece attached to the outer side of the middle and anterior coxæ.

\section{Table for Determining the Families of Hymenoptera.}

(Arranged by permission from Cresson's Synopsis of the Hymenoptera of North America.)

A-Posterior trochanters one.jointed.

B-Anterior wings with at least on $\theta$ closed complete sub-marginal cell.

C-Posterior tarsi with the basal joint more or less compressed and dilated, and densely pubescent beneath.

D-Labium slender, not flattened, longer than the mentum; basal joints of the labial palpi elongate............................ (A pidæ.)

DD-Labium flattened, shorter than the mentum; basal joints of the labial palpi not unlike the following foints.................. (Andrenidæ.)

CC-Posterior tarsi with the basal joint more or less cylindrical, never much widened or densely pubescent.

$\mathrm{D}$-Petiole of the abdomen simple, without scales or nodes. 
E-Wings more or less folded longitudinally in repose; antennæ fliform or sub-filiform.

F--Intermediate tibiæ with two apical spurs................ (Vespidæ.)

FF-Intermediate tibiæe with one apical spur ............. (Eumenidæ.)

EE-Wings not folded longitudinally.

F-Prothorax usually consisting of little more than a narrow collar, the posterior angles not reaching the tegulæ: female never wingless.

G-Anterior wings with two complete sub-marginal cells.

H-Prothorax short, transverse; metathorax short, rounded posteriorly; clypeus not carinate or rostriform.

(Pemphredonidie.)

HH-Prothorax long and narrow, produced anteriurly into a neck; metathorax elongate, truncate behind; clypeus carinate and rostriform .............................. (Ampulicidæ.)

GG-Anterior wings with three complete submarginal cells.

H-Abdomen sessile or sub-sessile.

I-Second submarginal cell receiving both recurrent nervures.

J-Marginal cell not appendiculate; mandibles with exterior margin entire.

K-Labrum distinctly exserted, sometimes rostriform.

IKK-Labrum short, not exserted..............(Nyssonidæ.)

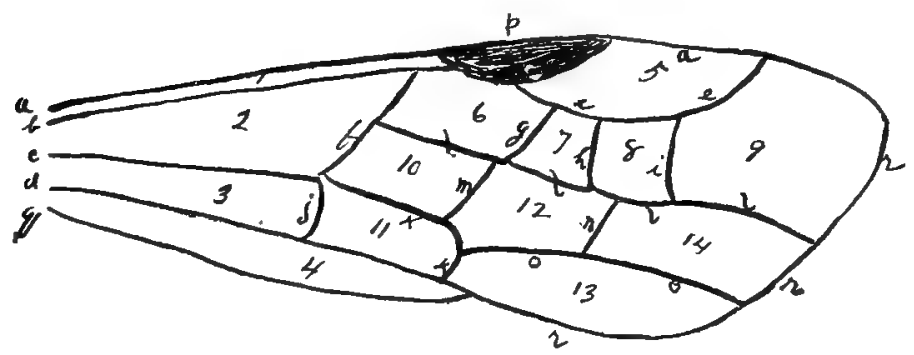

ANTERIOR WING OF HYMENOPTER (MELLINUS).

1.-Costal cell.

2.-Median cell, ,

3.-Sub međian celi.

4.-Anal cell.

5.-Marginal cell.

6.-First submarginal cell.

7.-Second submarginal cell.

8. - Third submarginal cell.

9.-Fourth submarginal cell.

10. - First discoidal cell.

11. - Second discoidal cell.

1:- Third discoidal cell.

13.-First apical cell.

14.--Second apical cell.
a.-Costal nerrure.

b. - Sub costal nervure.

c.-Externo-medial nervure.

c.-Anal nervure.

e--Marginal or radial nervure.

f.-Basal nervure.

g. - First transverso-cubital nervare.

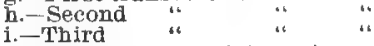

j.-Transverso-medial nervire.

1r.-Discoidal nervure.

1.-Cubital nervure.

im.-First recurrent nervure.

n.-Second

o.-Subdiscoidal nervure.

p.-Stigma.

ๆ.-Posterior margin.

r.-A picatl margiu.

JJ-Marginal cell appendiculate; mandibles deeply emarginate on the exterior naririn ....

II-Second and third submarginal wll eath resiving to recurrent nervure .......................... (Philanthidæ.)

HH-Abdomen peliolate. 
I-First submarginal cell not receiving a recurrent nervure.

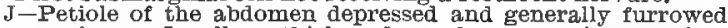
above; flagellum thickened at the apex; intermediate tibire with one apical spur ................. (Mimesidu.)

JJ-Petiole of the abdomen cylindrical, smooth; flagellum slender at the apex: intermediate tibiæ with two apical spurs ................................. (Sphecidæ.)

II-First submarginal celi receiving a recurrent nervure.

GGG-Anterior wings with only one complete submarginal cell.

(Mellinidæe.)

(Crabronidæ.)

FF-Prothorax considerably produced posteriorly, the hinder angles reaching the tegulp; female sometimes wingless.

G-Abdomen with the first ventral segment not separated from the second by a furrow or constriction of the joint.

H-Posterior legs long, reaching beyond apex of the abdomen; eyes not emarginate within ..................(Pompilidæ.)

HB-Posterior legs short, not reaching to the tip of the abdomen; eyes emarginate within ........ ............ (Sapygidæ.)

$\mathrm{GG}$-Abdomen with the first ventral segment distinctly separated from the second by a constriction or furrow.

$\mathrm{H}$-Intermediate tibia with one apical spur; female winged.

(Scoliidæ.)

HH-Intermediate tibiæ with two apical spurs; female wingless.

(Mutillidæ)

DD-Petiole of the abdomen with one or more scales or nodes; three sexes, or kinds of individuals.

I-Petiole composed of a single joint.

F-Abdomen proper not constricted between segments one and two.

FF-Abdomen proper constricted between segments one and two.

(Formicidæ.)

(Poneridæ.)

EE-Petiole composed of two joints

BB-Anterior wings without complete or closed submarginal cells.

C-Abdomen sessile, a little longer than the head and thorax, composed apparently of only 3 to 5 segments, the remainder modified into a slender, retractile, telescopic apparatus, generally not exserted; antennæ elbowed, short; body adorned with metallic colors, and often coarsely and deeply sculptured ............................... (Chrysididæ.)

CC-Abdomen petiolate, of the female very long, at least 5 times as long as the head and thorax; antennæe long, thread-like, not elbowed; body black, smooth and polished.......................... (Pelecinidæ.)

A A-Posterior trochanters two jointed.

I3-Abdomen sessile or petiolate, united to the thorax by a portion only of its transverse diameter, the articulation movable.

C-Anterior wings almost veinless, without closed or perfect cells.

D-Posterior margin of prothorax reaching the tegula; ovipositor arising from the apex of the abdomen .................. (Proctotrupiare.)

DD-Posterior margin of the prothorax not reaching the tegulge; ovipositor arising before the apex of the abdomen...........(Chaleididæ.)

CC-Anterior wings with several closed or nearly closed marginal or submarginal cells.

D-Anterior wings with a costal nervure and a more or less developed stigma.

E-Abdomen attached to the extremity of the metathorax.

F-Anterior wings with but one recurrent nervure ....... (Braconidæ.)

FF-Anterior wings with two recurrent nervures ..... (Ichneumonidre.)

EE-Abdomen inserted upon the dorsum or near the base of the meta-

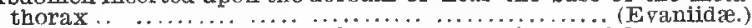

DD-Anterior wings without a costal nervure or stigma; abdomen generally ovate, and more or less compressed ............ (Cynipida.)

BB-Abdomen connate, united with the thorax by the entire diameter of the basal part, the articulation not movable,

C-Anterior tibiæ with one apical spur; abdomen of the female furnished at the tip with a borer............................. (Urocerida.)

CC-Anterior tibiæ with two apical spurs; abdomen of the female furnished at the tip with a pair of saws ........................ (T'enthredinidre.) 


\section{Glossary for the Table of Hymonoptera.}

Apical situated at or near the apex.

Appendiculate-said of a cell that has an incomplete vein extending from one of its corners.

Cell-a space in the wing bounded by veins. For the names of the different cells, see the figures of wings.

Carinate-furnished with a ridge.

Clypeus-that part of the upper or front side of the head which lies just be. hind the labrum.

E'marginate-notched.

Exserted-projecting out.

Flagellum-the terminal portion of the antenna, usually consisting of ten to twelve segments.

Filiform-thread-like; slender.

Mentum - that part of the under side of the head which lies immediately behind the labium.

Petiole-the slender rod which connects the abdomen and the thorax, as seen on a wasp.

Pubescent covered with tine hairs.

Recurrent Nervures - see figures of wings.

Rostriform - shaped like a beak.

Sessile-without a petiole.

Tegula-a small plate or scale overlapping the base of the fore wing.

Truncate-cut squarely off. 


\section{N D E X.}

Absolute alcohol, 175, 178.

Acephala, 138.

Acrididæ, 26.

Age of fishes, 102; of reptiles, 102; of invertebrates, 102.

Agricultural ant, 53 .

Agrionidæ, 47, 172.

Air bladder, 88.

Air sacs, 115.

Air tubes, 20 .

Alcohol, 176.

Alternation of generations, 156 .

Amoeba, 163, 175.

Amphioxus, 132.

Analytical tables for determining the families of insects, 185-202. Anosia plexippus, 36, 171 .

Ant, agricultural, 53.

Ant, leaf-cutting, 53.

Ants, 53.

Aquaria, 175.

Arachnida, 62.

Araneina, 62.

Archæopteryx, 119.

Argiope riparia, 172.

Arthromeres, 152.

Arthropoda, 13-78, 164.

Articulates, 164.

Astacus, 74.

Authority, 26.

Bacteria, 175.

Basilarchia archippus, 36 .
Batrachians, 100.

Beavers, 130.

Beeswax, 59.

Beetle, 37, 171.

Bell animalcule, 160.

Belostoma americanum, 39.

Bénacus griseus, 39.

Bilateral symmetry, 152.

Birds, 104, 113.

Bivalves, 138.

Blattidæ, 31.

Blood corpuscles, 95.

Bollworm, 37.

Bombycidæ, 36.

Bombyx mori, 36.

Bot flies, 45.

Brachiopods, 149.

Branches of Animal Kingdom, 77, $167,182$.

Breathing, of grasshopper, 23; of fish, 86; of frog, 94.

Budding, 156.

Bumblebee, 47.

Butterfly, 32, 171.

Calcareous shell, 120.

Cambarus, 74.

Carchesium, 161.

Carpet beetle, 38 .

Caterpillar, 33, 171.

Cecropia moth, 35, 171.

Cell, 99, 158, 164, 166.

Centaur, 133. 
Centipede, 63, 172.

Checks on increase, 24, 131.

Chilognatha, 65.

Chilopoda, 65.

Chinch bug, 41.

Chitin, 22.

Chlorophyl, 160.

Chrysalis, 33, 171.

Cicada, 39.

Circulation, of fish, 87; of frog, 94; of bird, 115 .

Cladocera, 75.

Clam, 135, 174.

Classes of animals, 55, 182.

Click beetles, 38 .

Clothes moth, 37 .

Clover seed, 51.

Cochineal, 59.

Cockroach, 31.

Cocoon, 33, 171.

Codling moth, 37.

Colenterata, 155, 164.

Collecting and preserving insects, 59 .

Collecting and preserving material, 170.

Coleoptera, 37.

Comparison of $\mathrm{tadpole}$ and fish, 98.

Comparison of pigeon and turtle, 118.

Complete or indirect metamorphosis, 35.

Complex structure", 168

Compound eye, 19.

Comstock boxes, 177.

Comstock's Entomology, 60.

Contractile vesicle, 161.

Copepoda, 75.

Corpuscles, 9.5.

Cotion worm, 37.
Cow flies, 45.

Crab, 75.

Crawfish, 68, 73, 173.

Crawling of earthworm, 146.

Cricket, 27, 170.

Crop of grasshopper, 19.

Cross fertilization of plants, 51 .

Crustacea, 73.

Curculio, 38.

Cyanide bottle, 60 .

Cyclops, 72, 175.

Cypris, 75, 175.

Daddy longlegs, 61.

Daphnia, 72, 175.

Definition, logical, 56, 78, 129, 168.

Dermestids, 38, 177.

Development, stages of, 34, 100.

Devil's darning needle, 46 .

Diapheromera femorata, 30 .

Dipnoi, 86.

Diptera, 42, 45.

Directions to students, 9.

Direct or incomplete metamorphosis, 23.

Dragon fly, 46, 172.

Drawings, 10.

Drone bees, 50.

Dry fly, 40.

Ducks. 117.

Earthworm, 145, 174.

Echinoderms, 151.

Egg, 99, 110, 116, 165, 173.

Electric light bug, 39.

Elytra, 37.

Embryologic series, 101-103.

Endoskeleton, 89, 114.

Enemies of grasshopper, 24.

Entomology, 59.

Epistylis, 161. 
Exoskeleton, 22, 114.

Eye, compound, 19.

Facets of compound eye, 19.

Feathers, 110.

Fish, 79, 173.

Fission, 165.

Fly, 42.

Food of grasshopper, 24 .

Formalin, 173, 174, 175.

Formic acid, 50.

Fresh-water clam, 135, 175.

Fresh-water sponge, 157, 175.

Frog, 91, 173.

Fur beetles, 38.

Gall gnats, 45.

Ganoidei, 86.

Garpike, 85.

Gasteropods, 144.

Geese, 117

Gemmule, 15\%, 159.

Genera, 26.

Geologic series, 108.

Germinal disc, 116.

Giant water bug, 38, 1 '71.

Gill breathing, 73.

Gill scoop, 74.

Gizzard of cricket, 28.

Gizzard of pigeon, $10 \%$.

Glossary, 190, 194, 199, 202.

Gnat, 45.

Gordius, 149.

Grasshopper, 13, 170.

Gryllidæ, 28; Gryllus abbreviatus, 28; Gryllus luctuosus, 28.

Gypsy moth, 37, 131.

Habits of earthworm, 148.

Hair worm, 25.

Harpalus, 171.
Harvest fly, 40.

Heart, single, 87 - respiratory, 87 .

Hemiptera, 40.

Hermaphroditism, 147.

Hessian fly, 45.

Heterocercal tail, 86.

Heteromyenia argyrosperma, 159.

Heteroptera, 41.

Hind wing of wasp, 49 .

Hinge ligament, 140.

Homocercal tail, 86.

Homology, 35, 66, 114.

Homoptera, 41.

Honey, 50.

Hoppers, tree, 41.

Hornet, 48, 172.

House fly, 42, 172.

Hydra, 155, 175.

Hydrachna belostoma, 39.

Hydranth, 156.

Hydroids, 156.

Hymenoptera, 50.

Icerya purchasi, 132.

Imago, 34, 36.

Immortality of Protozoa, 165

Improper questions, 10.

Incisors, 130.

Incomplete or direct metamorphosis, 23.

Incubation, 116.

Indirect or complete metamorphosis, 35.

Individual, 156.

Injury done by grasshoppers, 24; by moths, 37 ; by insects, 59 ;

by rabbits, 130 .

Insecta, 13-60.

Insect net, 59 .

Insects, orders of, $54,183$.

Instruments, 11, 176. 
Jelly fishos, 155.

Jugging bumblebees, 172 .

Katydid, 29, 170.

Keratin, 114.

Labellæ, 43.

Lamellibranchiata, 138.

Larva, 34.

Leaf-cutting ant, 53.

Leech, 149.

Libellulidæ, 47, 172.

Lingual ribbon, 143.

Locomotion of fishes, 86; clam, 138; earthworm, 146.

Locustidæ, 29.

Logical definition, 56, 78, 129, 168.

Logical identity, 67 .

Lung fishes, 86.

Madreporic body, 153.

Maggot, 45.

Mammals, 130.

Mantidæ, 31.

Mantis, 31.

Melanoplus differentialis, 170.

Melanoplus spretus, 24.

Metamorphosis, 23, 35.

Mice, 130.

Micrographic camera, 180.

Migration of birds, 117.

Mimicry, 36.

Minnow, 85.

Mollusks, 138, 149, 164.

Molting, 23.

Mosquito, 45.

Mosquito hawk, 46.

Moth, 34, 171.

Mounting microscopic objects, 177.

Muciparous glands, 89 .

Mud nests, 52, 172,
Muscle fiber, 20.

Mussel, 152.

Myenia fluviatilis, 160 .

Mylohyoid muscle, 95.

Myriapoda, 65 .

Names, rules for, 26 .

Nectar, 50.

Nematocysts, 156.

Neuroptera, 46.

Neuters, 50.

Nictitating membrane, 104, 134.

Notebook, 10, 176.

Notochord, 86, 132.

Nucleus, 87, 116.

Number of species of insects, 59 .

Odonata, 47.

Odontophore, 144.

Ontogenetic series, 101-103.

Orders of insects, 54,183 ; of reptiles, 120, 184.

Orthoptera, 31.

Ostracoda, 75.

Oyster, 140, 174.

Paramœeium, 162, 175.

Parasites, 25.

Parthenogenesis, 41.

Pedicellariæ, 153.

Peristome, 160.

Phalangidea, 62.

Phasmide, 30.

Phylogenetic series, 103.

Pigeon, 104.

Pisces, 85.

Plant lice, 41, 53.

Poison of bee, 50 ; of spiders, 63 .

Pollen, 50.

Pollen basket, 47 .

Porifera, 15\%, 167, 182. 
Porte lumiere, 178.

Praying mantis, 31.

Pressure upon subsistence, 132.

Proboscis of fly, 42.

Productions of insects, 59.

Proper questions, 10.

Protective coloration, 25, 29, 36.

Protective resemblance, 30 .

Protoplasm, 163.

Protozoa, 102, 160, 165.

Punctorial bristle, 38.

Pupa, 34.

Queen bees, 50.

Rabbit, 121, 130.

Radiates, 152, 164.

Radula, 144.

Rats, 130.

Reproduction by fission (protozoa), 165.

Reproduction of parts, 153, 156.

Reptiles, orders of, 120 .

Review topics, $21,56,75,89,98$, 111, 126, 153, 168.

Rodentia, 130.

Rudimentary organs, 36 .

Rules for naming, 26.

Salamander, 100.

Samia cecropia, 36.

San Jose scale, 131.

Sauropsida, 119.

Scales from wing of butterfly, 35 .

Scolopendra, 66 .

Scolopocryptops, 65.

Segmentation of the egg, 116.

Selachii, 85.

Senses of insects, 24.

Setting board, 60, 177 .

Seventeen year cicada, 40 .
Sharks, 85 .

Shellac, 59 .

Silk, 36.

Silky locust mite, 24 .

Skeleton, 22.

Slipper animalcule, 162.

Slug, 144, 175.

Snail, 142, 175.

Snake doctor, 46.

Social organization, 50

Solitary wasps, 52.

Sow bug, 71, 173.

Species, 26.

Species of insects-number of, 59 .

Spicules, 158.

Spider, 61, 172.

Spider webs, 63.

Spinnerets, 63.

Spiracles, 15, 20, 28.

Sponge, 157.

Spongiolin, $15 \%$.

Squash bug, 39, 171.

Squirrels, 130.

Stages of development, 34, 100.

Starfish, 140, 150, 175.

Stentor, 162, 175.

Sting, 49 .

Struggle for existence, 132.

Sturgeon, 85.

Survival of the fittest, 132.

Symphoricarpus, 62.

Synopsis of chapters, 7 .

Tables for determining the families of insects, 185-202.

Table of addition of organs, $16 \%$.

Tables of differences, $30,34,55$, $65,77,96,98,111,128,129,141$, $143,150$.

Tables of resemblances, 31,55 , $77,118,129,141,143,164,166$. 
Tachina flies, 25.

Tadpole, 97, 173.

Tapeworm, 131.

Taxonomic series, 102-103.

Teleostei, 85.

Temperature of birds, 115.

Tent caterpillar, 37.

Tetradecapoda, 75.

Thousand legs, 64 .

Toad, 96, 173.

Tobacco moth, 37.

Tomato moth, 37 .

Tongue of bee, 48 ; of wasp, 49 .

Tracheæ, 20.

Tree hoppers, 41.

Trichina, 149.

Turtle, $11 \%$.

Univalves, 144.

Useful products of insects, 59 .

Vermes, 148, 164.
Vermiform appendix, 134.

Vertebrates, 129, 164.

Vestigial organs, 36, 134.

Vinegar worm, 149.

Von Baer's principle, 99.

Vorticella, 161, 175.

Walking stick, 30, 171.

Warning colors, 51.

Wasp, 48, 52.

Wasp nests, 52.

Wax, 50.

Webs, 63.

Wheel bug, 41.

Wiggler, 45.

Wire worms, 38.

Wood borers, 38.

Woodpeckers, 117.

Wolf-berry, 62.

Zaitha fluminea, 39, 171.

Zoölogic series, 102-103. 


QL 53

Na

H 34

Name

Address 
